GUSTAVO CABRAL DE MIRANDA

Novos biossensores baseados em anticorpos naturais e sintéticos para detecção de LDL oxidada (oxLDL) usada como biomarcador de aterosclerose

Tese apresentada ao Programa de Pós-Graduação em Imunologia do Instituto de Ciências Biomédicas da Universidade de São Paulo, para obtenção do Título de Doutor em Ciências. 
GUSTAVO CABRAL DE MIRANDA

Novos biossensores baseados em anticorpos naturais e sintéticos para detecção de LDL oxidada (oxLDL) usada como biomarcador de aterosclerose

Tese apresentada ao Programa de Pós-Graduação em Imunologia do Instituto de Ciências Biomédicas da Universidade de São Paulo, para obtenção do Título de Doutor em Ciências.

Área de concentração: Imunologia

Orientador: Prof ${ }^{o}$ Dro ${ }^{o}$ Magnus Ake Gidlund

Versão original 
DADOS DE CATALOGAÇÃO NA PUBLICAÇÃO (CIP)

Serviço de Biblioteca e Informação Biomédica do Instituto de Ciências Biomédicas da Universidade de São Paulo

(c) reprodução total

Miranda, Gustavo Cabral de.

Novos biossensores baseados em anticorpos naturais e sintéticos para detecção de LDL oxidada (oxLDL) usada como biomarcador de aterosclerose / Gustavo Cabral de Miranda. -- São Paulo, 2014.

Orientador: Prof. Dr. Magnus Ake Gidlund.

Tese (Doutorado) - Universidade de São Paulo. Instituto de Ciências Biomédicas. Departamento de Imunologia. Área de concentração:

Imunologia. Linha de pesquisa: Imunologia aplicada ao desenvolvimento de diagnóstico da aterosclerose.

Versão do título para o inglês: New biosensors based on natural and synthetic antibodies for the detection of oxidized LDL (oxLDL) used as a biomarker for atherosclerosis.

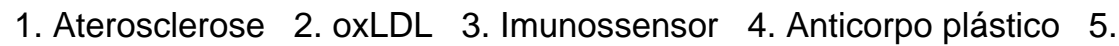
Biosensor I. Gidlund, Prof. Dr. Magnus Ake II. Universidade de São Paulo. Instituto de Ciências Biomédicas. Programa de Pós-Graduação em Imunologia III. Título. 
Candidato(a): $\quad$ Gustavo Cabral de Miranda.

Título da Tese: $\quad$ Novos biossensores baseados em anticorpos naturais e sintéticos para detecção de LDL oxidada (oxLDL) usada como biomarcador de aterosclerose.

Orientador(a):

Prof. Dr. Magnus Ake Gidlund.

A Comissão Julgadora dos trabalhos de Defesa da Tese de Doutorado, em sessão pública realizada a

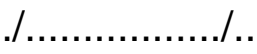
considerou
( ) Aprovado(a)
( ) Reprovado(a)

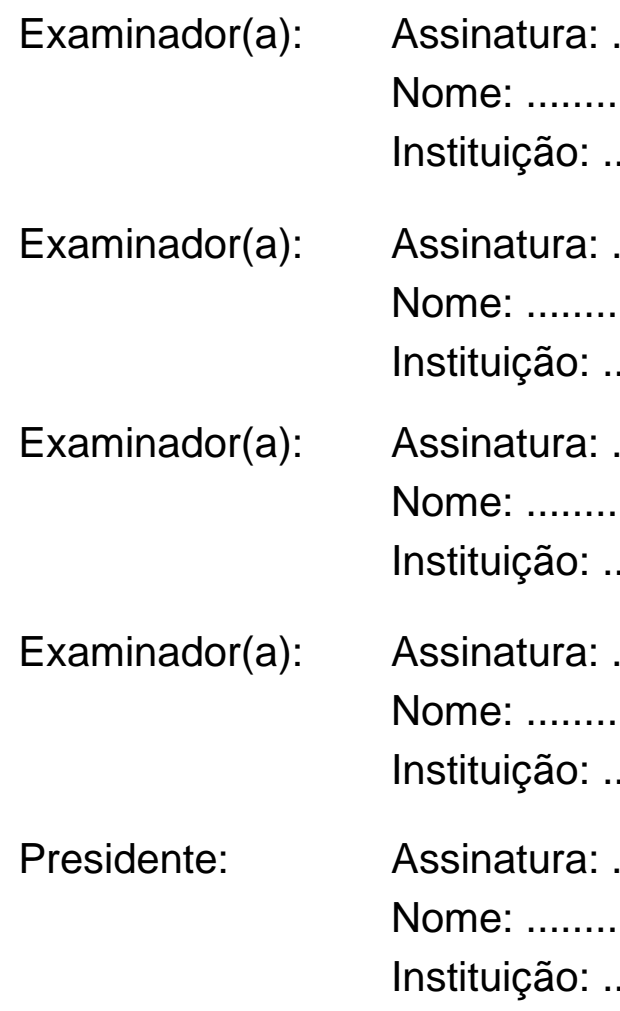




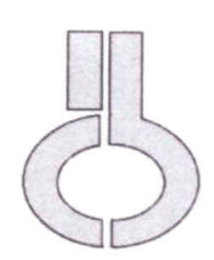

UNIVERSIDADE DE SÃO PAULO

INSTITUTO DE CIÊNCIAS BIOMÉDICAS

Cidade Universitária "Armando de Salles Oliveira"

Av. Prof. Lineu Prestes, 2415 - CEP. 05508-000 São Paulo, SP Brasil

Telefone :(55) (011) 3091.7733 - e-mail: cep@icb.usp.br

c. 6

\section{CertificADO}

Certificamos que o protocolo registrado sob n ${ }^{0} \mathbf{1 1 6}$ nas fls. 109 do livro 02 para uso de animais em experimentação, sob a responsabilidade do Prof(a) $\operatorname{Dr}(a)$ ) Magnus Ake

Gidlund, Coordenador (a) da Linha de pesquisa "Produção de anticorpos monoclonais anti-oxLDL visando o desenvolvimento de biossensores para imunodiagnóstico da aterosclerose" do qual participam o(s) aluno(s) Gustavo Cabral de Miranda e os pesquisadores Hermi Felinto de Brito, Hiro Goto, Nágila Raquel Teixeira Damasceno, está de acordo com os Princípios Éticos de Experimentação Animal adotado pela Sociedade Brasileira de Ciência de Animais de Laboratório (SBCAL) e foi aprovado pela COMISSÃO DE ÉTICA NO USO DE ANIMAIS (CEUA) em 24.02.2012, com validade de 4 anos.

São Paulo, 28 de fevereiro de 2012.
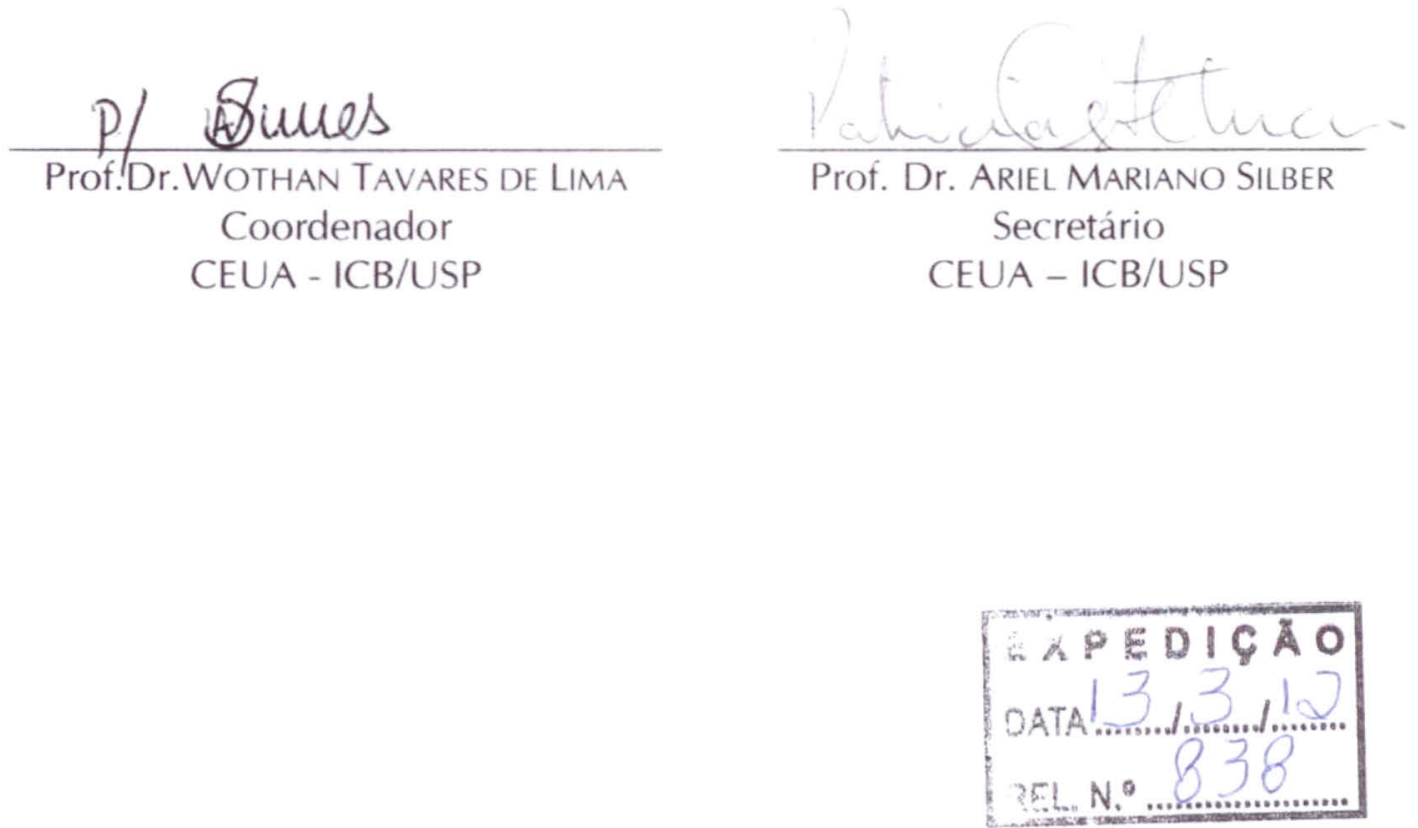
A Comissão de Ética em Pesquisas com Seres Humanos do ICB, na sessão realizada no dia 07.12.2011, APROVOU o projeto intitulado: "Produção de anticorpos monoclonais anti-oxLDL visando o desenvolvimento de biossensores ópticos para imunodiagnóstico da aterosclerose " sob responsabilidade de execução dos autores Prof. Dr. MAGNus AKE Gidlund e o aluno Gustavo Cabral de Miranda.

Cabe a pesquisadora executante elabora e apresentar a este Comitê, relatórios anuais (parciais ou final), de acordo com a resolução 196/06 do Conselho Nacional da Saúde, item IX. 2 letra c.

O primeiro relatório deverá ser encaminhado à Secretaria deste CEP em

07.12.2012.

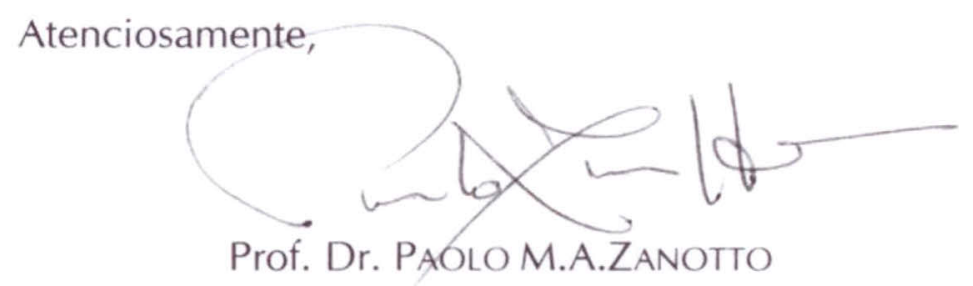

Coordenador da Comissão de Ética em

Pesquisas com Seres Humanos - ICB/USP

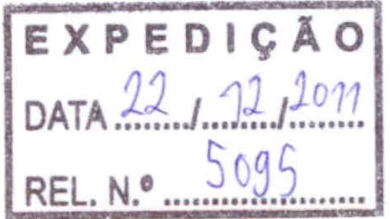

Comissão de Ética em Pesquisa com Seres Humanos do Instituto de Ciências Biomédicas / USP Aprovada pela Comissão Nacional de Ética em Pesquisa - CONEP, em 10 de fevereiro de 1998. 
Essa conquista é dedicada ao meu pai Washington R. de Miranda e minha mãe Maria das Graças C. de Miranda, por me darem tanto amor e sabedoria. Essa realização é por vocês que amo de forma incondicional!

Além de meus pais, essa conquista é para toda minha família que se torna completa com minha irmã Eliana, e meus irmãos Flávio e William.

Ao meu irmão e melhor amigo William Cabral de Miranda que vem construindo e compartilhando comigo uma história de vida.

À minha namorada Jéssica Vidal Damasceno por ser tão companheira em todos os momentos que temos desde que nos encontramos. 


\section{AGRADECIMENTOS}

Ao meu orientador Profo Dro Magnus Ake Gidlund pela confiança em meu potencial e por ter sido essencial para esta conquista.

À Dra Maria Goreti Ferreira Sales, por me receber para orientar durante meu doutorado sandwich no exterior. Drª Goreti e todo grupo "BioMark" estão e ficarão para sempre como pessoas muito especiais em minha vida!

À Edite Hatsumi Yamashiro Kanashiro por ter contribuido sempre com muita sabedoria e alegria para o desenvolvimento do projeto.

À Prof ${ }^{-a}$ Dra ${ }^{a}$ Hiro Goto por abrir as portas de seu laboratório para eu poder fazer parte dos trabalhos deste projeto de tese.

À Prof ${ }^{\underline{a}}$ Dr ${ }^{\underline{a}}$ Neuza Ma Alcântara Neves, minha orientadora durante o mestrado (ICSUFBA), por todo ensinamento que me deu. Pois se hoje eu consigo fazer um trabalho como este, agradeço muito à Profa ${ }^{-}$Neuza.

Ao Dro Artur Gomes Dias Lima, meu orientador no período de Iniciação científica.

Aos colegas e companheiros de laboratório ICB-IV/USP: Andreia M. Monteiro, Rafael Trentin e Silvana Silva.

Aos Professores membros da banca de minha qualificação, Profo ${ }^{\circ}$ Dro Anderson de Sá

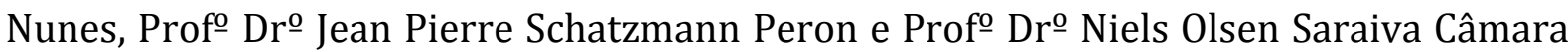
(Presidente da Banca) por terem ajudado de forma significativa para melhorar a escrita da tese e por terem opinado de forma construtiva para minha formação acadêmica.

Aos professores do Departamento de Imunologia que ajudaram em minha formação através de aulas e palestras. 
Ao coordenador do Programa de Pós-Graduação em Imunologia, Profo Dro Gustavo P. Amarante Mendes, por está sempre com muita disposição para ajudar no que fosse necessário para minha formação.

Aos funcionários da secretaria: Amanda Souza, João Pinheiro, Jotelma Ribeiro e Maria Eni.

À Coordenação de Aperfeiçoamento de Pessoal de Nível Superior (CAPES) e ao Conselho Nacional de Desenvolvimento Científico e Tecnológico (CNPq), programa Ciência sem Fronteiras, pelo apoio financeiro através de bolsas de estudo e apoio para ir a congressos, fundamental para a realização deste doutorado. 
"I'm just a dreamer

I dream my life away

I'm just a dreamer

Who dreams of better days"

(Dreamer, Ozzy Osbourne) 


\section{RESUMO}

CABRAL-MIRANDA, G. Novos biossensores baseados em anticorpos naturais e sintéticos para detecção de LDL oxidada (oxLDL) usada como biomarcador de aterosclerose. 2014. 110 f. Tese (Doutorado em Imunologia) - Instituto de Ciências Biomédicas, Universidade de São Paulo, 2014.

Vários estudos que tentam compreender a gênese da aterosclerose têm demonstrado evidências que a oxLDL é peça importante para o desenvolvimento da doença, tornandoa um importante marcador. Os objetivos deste trabalho foram propor um novo imunossensor empregando anticorpos monoclonais anti-oxLDL e desenvolver um processo inovador de obtenção de anticorpos plásticos anti-oxLDL como técnicas eficazes para monitorar oxLDL circulante. Para construção do imunossensor, a região Fc do anticorpo foi ligada ao eletrodo de trabalho do dispositivo AuSPE (Screen-Printed Gold Electrodes), utilizando cisteamina como monocamada auto-organizada. Antes da adição dos anticorpos sobre a cisteamina, estes tiveram as regiões carboxílicas ativadas com NHS e EDAC a $25 \mathrm{mM}$. Posteriormente, foi adicionado BSA como bloqueador de possíveis regiões livres do AuSPE. Após o bloqueio, obteve-se, assim, o imunossensor em condições de testes. Para isso, oxLDL foi diluído em PBS e, posteriormente, em soro fetal bovino como forma de aproximação aos testes em condições reais. Para garantir a especificidade do imunossensor, este foi testado também com outros antígenos, como LDL não oxidada, hemoglobina e mioglobina. Todas as etapas de modificação química sobre o AuSPE foram medidas com EIS (electrochemical impedance spectroscopy) e SWV (square wave voltammetry). Em relação aos anticorpos plásticos, estes foram chamados MAPS (Materials Antibody Plastic Smart) em alusão ao inverso do nome SPAM (Smart Plastic Antibody Materials), o qual foi referência para desenvolvimento deste material biomimético. Para superar a dependência da espessura do polímero, o trabalho desenvolvido propôs uma camada impressa de forma invertida do anticorpo plástico SPAM. Após obtenção dos MAPSs, estes passaram por diversos testes, similarmente ao imunossensor. Os resultados demonstraram excelente sensibilidade e especificidade às moléculas de oxLDL com detecção em tempo real em ambas as metodologias. Desse modo, concluiu-se que essas novas técnicas são bastante promissoras para aplicação na rotina laboratorial clínica.

Palavras-chave: Aterosclerose. oxLDL. Imunossensor. Anticorpo Plástico. Biossensor. 


\begin{abstract}
CABRAL-MIRANDA, G. New biosensors based on natural and synthetic antibodies for the detection of oxidized LDL (oxLDL) used as a biomarker for atherosclerosis. 2014. 110 p. Ph. D. thesis (Immunology) - Instituto de Ciências Biomédicas, Universidade de São Paulo, 2014.

Increased levels of plasma oxLDL are associated with atherosclerosis, and the subsequent development of severe cardiovascular diseases that are today a major cause of death in modern countries. It is therefore important to find a reliable and fast assay to determine oxLDL in serum. A new Immunosensor employing three monoclonal antibodies against oxLDL and a backside protein-surface imprinting process are proposed in this work as a quick and effective way to monitor oxLDL and as a novel way to generate specific synthetic antibody material. To generate the Immunosensor the mAbs were set-up by selfassembling cysteamine (Cys) on a gold (Au) layer of a disposable screen-printed electrode. The mAbs were allowed to react with NHS and EDAC, and subsequently incubated in the Au/Cys. Albumin from bovine serum (BSA) was immobilized further as bloker. All steps were followed by various characterization techniques such as electrochemical impedance spectroscopy (EIS) and square wave voltammetry (SWV). The analytical operation of the immunosensor was obtained by incubating the sensing layer of the device in oxLDL for 15 minutes, prior to EIS and SWV. To generate specific synthetic antibody material, the template is covalently bond to a carboxylated-PVC supporting film previously casted on gold, let interact with charged monomers and surrounded next by another thick polymer. This polymer is then covalently attached to a transducing element and the backside of this structure (supporting film plus template) removed as a regular "tape". The new sensing layer is exposed after full template removal, showing a high density of re-binding positions, as evidenced by SEM. To ensure that the templates were efficiently removed, this rebinding layer was cleaned further with proteolytic enzyme and solution washout. It was able to generate, for the first time, a specific response to a complex biomolecule from a synthetic material. The devices were successfully applied to determine the oxLDL fraction in real serum, without prior dilution or necessary chemical treatment. Overall, these were promising results with the possibility to apply on the practical use of clinical.
\end{abstract}

Keywords: Atherosclerosis. oxLDL. Immunosensor. Plastic antibody. Biosensor. 


\section{LISTA DE ILUSTRAÇÕES}

Figura 1 - Princípios da construção dos Biossensores.

Figura 2 - Princípios da construção dos Polimeros Impressos Molecularmente.

Figura 3 - Equipamentos utilizados nos experimentos eletroquímicos.

Figura 4 - Desenho esquemático referente ao processo de construção do imunossensor.

Figura 5 - Desenho esquemático referente ao processo de construção do MAPS.

Figura 6 - Isotipagem dos anticorpos anti-oxLDL

Figura 7 - Testes da seletividade do imunossensor utilizando (A) mioglobina, (B) LDL não oxidada e (C) hemoglobina, como controles negativos

Figura 8 - Resposta eletroquímica EIS do imunossensor, utilizando os anticorpos (Ac) 73 (A), Ac73 (B) ou Ac87 (C) separadamente

Figura 9 - Respostas eletroquímicas EIS obtidas com a montagem do imunossensor utilizando os três anticorpos juntos.

Figura 10 - Gama linear da curva de calibração do imunossensor.

Figura 11 - Resposta eletroquímica EIS do imunossensor com FCS sem oxLDL (A) ou FCS com oxLDL (B)

Figura 12 - Curva de calibração do Imunossensor utilizando oxLDL diluída em FCS

Figura 13 - Gama linear da curva de calibração do imunossensor com oxLDL variando de 0,5 a $15,5 \mu \mathrm{g} / \mathrm{mL}^{-1}$.

Figura 14 - Resposta da montagem por SWV do imunossensor e a curva de calibração diluíndo oxLDL em FCS.

Figura 15 - Ensaios eletroquímicos EIS durante a construção dos anticorpos plásticos.

Figura 16 - Imagem por SEM da superfície não-impressa (esquerda, NIM) e o material impresso, anticorpos plásticos (direito, MAPS). 
Figure 18 - Respostas eletroquímicas EIS dos MAPS (A) e NIM (B) a altas concentrações de oxLDL diluida em PBS

Figura 19 - Testes de especificidade do MAPS contra proteínas do soro que coexistem com oxLDL, (A) mioglobina, (B) hemoglobina e (C) LDL não oxidada

Figura 20 - Comparação das respostas eletroquímicas EIS do MAPS utilizando oxLDL e LDL não oxidada.

Figura 21 - Curva de Calibração do MASP com oxLDL diluida em FCS. 


\section{LISTA DE TABELAS}

Tabela 1 - Curva de Calibração da oxLDL nas concentrações de 5 a 30 $\mu \mathrm{g} / \mathrm{mL}^{-1}$

Tabela 2 - Curva de Calibração da oxLDL diluido em FCS nas concentrações de 0,5 a $21,5 \mu \mathrm{g} / \mathrm{mL}^{-1}$ 60

Tabela 3. Curva de Calibração com o MAPS para detecção de oxLDL diluida em FCS 
LISTA DE ABREVIATURAS E SIGLAS

\begin{tabular}{|c|c|}
\hline $\mathbf{A u}$ & Gold \\
\hline AuSPE & Screen-Printed Gold Electrodes \\
\hline BPO & Benzoyl Peroxide \\
\hline BSA & Bovine Serum Albumin \\
\hline Cys & Cysteamine \\
\hline DLS & Dynamic Light Scattering \\
\hline DMEM & Dulbecco's Modified Eagle's Medium \\
\hline EDAC & $\begin{array}{l}\text { N-Ethyl-N-(3-dimethylaminopropyl)-N-ethylcarbodiimide } \\
\text { hydrochloride }\end{array}$ \\
\hline EDTA & Ethylenediaminetetraacetic Acid \\
\hline EIS & Electrochemical Impedance Spectroscopy \\
\hline ELISA & Enzyme-Linked Immunosorbent Assay \\
\hline EGDMA & Ethylene Glycol Dimethacrylate \\
\hline Fab & Fragment Antigen Binding \\
\hline Fc & Fragment Crystallizable \\
\hline FCS & Fetal Calf Serum \\
\hline LC-MS & Liquid Chromatography-Mass Spectrometry \\
\hline LDL & Low Density Lipoprotein \\
\hline MAA & Methacrylic Acid \\
\hline MPA & Mercaptopropionic Acid \\
\hline MAPS & Materials Antibody Plastic Smart \\
\hline MIP & Molecular Imprinting Polymer \\
\hline mLDL & Modified Low Density Lipoprotein \\
\hline NHS & N-hydroxysuccinimide \\
\hline NIM & Non-imprinted Materials \\
\hline OPD & O-Phenylenediamine Dihydrochloride \\
\hline oxLDL & Oxidized Low Density Lipoprotein \\
\hline PBS & Phosphate Buffered Saline \\
\hline PMSF & Phenylmethylsulfonyl Fluoride \\
\hline PVC-COOH & Carboxylated Poly(vinyl chloride) \\
\hline QCM & Quartz Crystal Microbalance \\
\hline
\end{tabular}


SAMs Self-Assembled Monolayers

SEM Scanning Electron Microscope

SPR Surface Plasmon Resonance

SWV Square Wave voltammetry

TBARS Thiobarbituric Acid Reactive Substances

VB Vinil Benzoato 


\section{SUMÁRIO}

1 INTRODUÇÃO

1.1 oxLDL como importante marcador aterogênico......................................... 21

1.2 Os níveis plasmáticos de oxLDL em pacientes com várias condições

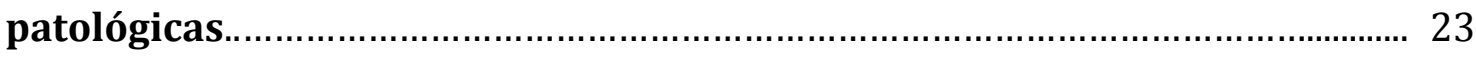

1.3 Os Métodos de deteç̧ão de oxLDL ......................................................... 25

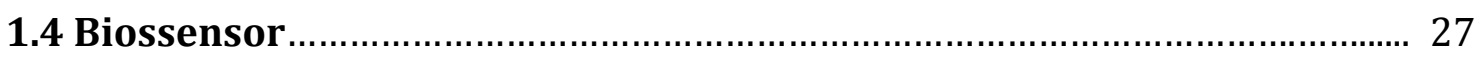

1.5 Polimeros Impressos Molecularmente ……………................................. 31

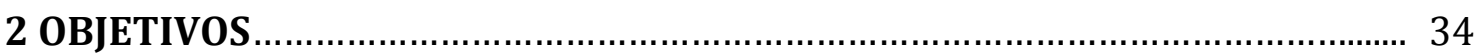

3 MATERIAL E MÉTODO ……………....................................................... 35

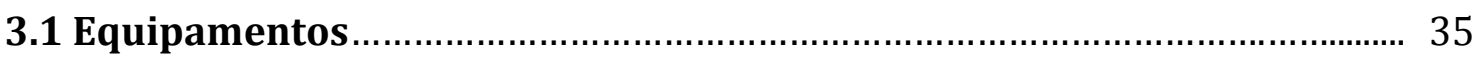

3.2 Obtenção e Purificação dos Anticospos Monoclonais …………………..... 37

3.3 Isotipagem dos Anticorpos quanto à Classe e Subclasse de Imunoglobulinas ................................................................................... 38

3.4 Obtenção e Oxidação das Lipoproteínas de Baixa Densidade..................... 39

3.5 Construção do Imunossensor Utilizando os Anticorpos 73, 77 e 87........ 39

3.6 Otimização do Imunossensor anti-oxLDL................................................... 41

3.7 Produção dos MAPS (Materials Antibody Plastic Smart) E NIM (Nonimprinted materials) ................................................................................ 42

3.8 Testes e Ensaios Eletroquímicos com os MAPS e NIM……………………….... 45

3.9 Visualização de Poros sobre os MAPS e NIM por microscopia eletrônica de varredura (SEM) ..................................................................... 46

3.10 Comparação de espetros Raman entre MAPS e NIM................................ 46

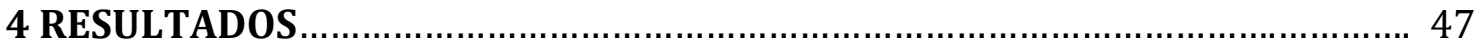

4.1 Peso e Tamanho das Partículas de oxLDL e do Complexo oxLDLAnticorpos por DLS............................................................................................ 47

4.2 Isótipos dos Anticorpos anti-oxLDL por ELISA Indireto ………………….. 47

4.3 Construção do Imunossensor ................................................................. 48

4.4 Estudo da Seletividade do Imunossensor ……………………………...... 49

4.5 Ensaios Eletroquímicos com o Imunossensor Utilizando os Anticorpos Monoclonais Separadamente ........................................................................ 51

4.6 Otimização do Imunossensor .................................................................... 53 
4.7 Testes do Imunossensor com oxLDL Diluido em Soro Fetal Bovino 56

4.8 Síntese dos Anticorpos Plásticos.......................................................... 63

4.9 Acompanhamento das Modificações Químicas no Au-SPE....................... 64

4.10 Análise dos Anticopos Plásticos por Microscopia Eletrônica de Varredura

4.11 Análise dos Anticopos Plásticos por Raman 68

4.11 Ensaios Experimentais com MAPS e NIM para detecção de moléculas de oxLDL 69

4.12 Testes dos MAPSs com Controles Negativo …....................................... 70

4.13 Testes dos MAPSs com oxLDL diluido em soro fetal bovino ................... 72

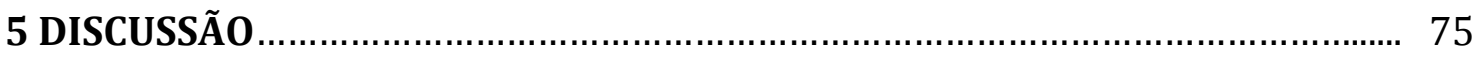

6 CONCLUSÃO

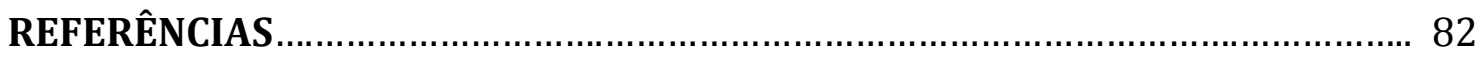

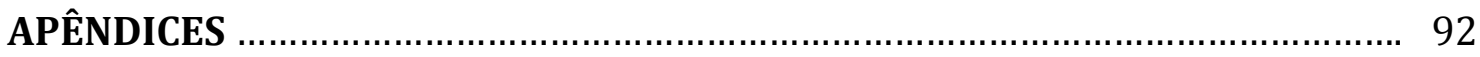

APÊNDICE A - 1ํo Artigo: Specific label-free and real-time detection of oxidized low density lipoprotein (oxLDL) using na immunosensor with three monoclonal antibodies.

APÊNDICE B - 2o Artigo: Backside-surface imprinting as a new strategy to generate specific plastic antibody materials 


\section{INTRODUÇÃo}

A aterosclerose é uma doença progressiva multifatorial que se manifesta por lesões dentro da parede arterial em resposta a várias agressões que afetam as células dos vasos (WORLD HEALTH ORGANIZATION, 2011). Não são recentes os esforços para explicar o complexo evento associado com o desenvolvimento de aterosclerose. Neste sentido, surgiram diferentes hipóteses para explicar o desenvolvimento das lesões, entre elas a que tem sido amplamente aceita na literatura é a modificação oxidativa da lipoproteína, a qual se baseia no conceito de que a LDL (low density lipoprotein) no seu estado nativo não é aterogênica; porém, se a LDL sofrer modificações químicas, esta é facilmente internalizada pelos macrófagos através de um receptor denominado "scavenger" (GOLDSTEIN et al., 1979). Este mecanismo foi descrito por vários autores (ASHRAF; GUPTA, 2011; CRUCET et al., 2013; KZHYSHKOWSKA; NEYEN; GORDON, 2012). Em 1984, Steinbrecher e colaboradores propuseram que a modificação oxidativa das moléculas de LDL promove a formação de células espumosas por macrófagos (STEINBRECHER et al., 1984) através da captação de oxLDL pelos receptors scavenger, o que conduz ao acúmulo de colesterol nas células e consequente transformação em células espumosas.

Além dos trabalhos supracitados, diversos estudos têm correlacionado altas concentrações de colesterol plasmático com o aumento do risco de doenças cardiovasculares (CASTELLI et al., 1986; CHOWDHURY et al., 2014; MANOLIO et al., 1992; NISSEN et al., 2005). Contudo, é importante citar que há outros fatores de risco apontados como indutores da aterosclerose, como idade, história familiar de doenças cardiovasculares, hipertensão, obesidade, diabetes, tabagismo e inatividade física (DAMASCENO et al., 2001; GIANNINI, 1998; LEPAGE et al., 2000), embora diversas linhas de pesquisa tenham mudado gradativamente a atenção para as frações das lipoproteínas modificadas, principalmente as lipoproteínas de baixa densidade modificadas por oxidação (GIDLUND et al., 1996; HOLVOET et al., 1998).

Outro fator que tem chamado bastante atenção para o conhecimento da formação das placas ateroscleróticas é a resposta imune gerada contra as moléculas de oxLDL. Esse conhecimento tem ampliado bastante a compreensão sobre a aterogênese, pois sabe-se que a oxLDL promove disfunção vascular, exerce citotoxidade direta sobre as células endoteliais e aumenta as propriedades quimiotáticas para monócitos e 
macrófagos, além da consequente transformação de macrófagos em células espumosas, contribuindo assim para aterosclerose (EHARA et al., 2001; FROSTEGARD, 2013; MAXFIELD; TABAS, 2005; STOCKER; KEANEY, 2003). Esses estudos têm contribuído de forma significativa para o entendimento sobre o processo aterosclerótico, onde há algumas décadas era definida de forma bastante simplória como uma resposta proliferativa que levava à injúria vascular (HANSSON; ROBERTSON; SODERBERGNAUCLER, 2006; ROSS, 1993) e que a lesão endotelial seria decorrente da agregação plaquetária, com liberação dos fatores de crescimento derivados de plaquetas, levando à proliferação e à migração de células musculares lisas para a camada íntima da artéria e formação do núcleo da lesão aterosclerótica. Essas definições não levava em consideração um fator muito importante, a inflamação, que ocorre para formar as placas ateroscleróticas.

Com a intensificação na busca por mecanismos de prevenção e possível inibição da progressão da aterosclerose, ampliaram-se os horizontes de sua fisiopatologia. Como resultado dos avanços tecnológicos e científicos os quais levaram a uma melhor compreensão da evolução da doença, a definição sobre aterosclerose passou a relacionar diversos fatores, sendo importante frisar o trabalho de Ross (1999) que deu uma definição para a aterosclerose como uma doença inflamatória. Seguindo esse conceito, muitos trabalhos mostram que a aterosclerose se caracteriza pelo espessamento e enrijecimento da parede das artérias, com o depósito de substâncias lipídicas, colesterol, restos de produtos celulares, cálcio e de outras substâncias na parede arterial, o que leva a formação de placas, denominadas ateromas (FRANÇOSO; COATES, 2012; PEJKOV et al., 2013), e que o processo inflamatório é bastante importante para o desenvolvimento da aterosclerose. Além disso, sabe-se que a placa de ateroma pode, em estágios mais avançados, bloquear parcialmente ou totalmente o fluxo de sangue pelas artérias e provocar ruptura da placa com o desenvolvimento de hemorragia e trombos, podendo levar à morte (WHO, 2011). 


\section{1 oxLDL como importante marcador aterogênico}

A detecção da oxLDL pelo receptor scavenger nos macrófagos conduz à absorção e ao acúmulo de colesterol e consequente transformação em células espumosas, as quais estão provadas como componentes importantes no processo de formação das lesões ateroscleróticas (ASHRAF; GUPTA, 2011; KZHYSHKOWSKA et al., 2012; STEINBRECHER et al., 1984). Mesmo com a absorção das moléculas de oxLDL pelos macrófagos, a presença dessas partículas circulante tem sido amplamente mostrada. Embora sejam necessários melhores esclarecimentos referentes às formas e locais que as moléculas de LDL são oxidadas, pois emergem evidências que a presença dessas partículas circulante deve-se ao fato que as moléculas de oxLDL acumulam-se nas lesões ateroscleróticas durante um longo período, conduzindo a lesões avançadas. Por outro lado, estudos mostram que mudanças de curso temporal in vivo são devido ao fato de que a oxLDL possa ser transferida entre as lesões e a circulação. Além disso, há trabalhos que mostram que a oscilação dos níveis de oxLDL no plasma talvez seja através da transferência entre os tecidos da parede dos vasos e circulação nos primeiros estágios da aterogênese (ITABE; OBAMA; KATO, 2011). Existem ainda, estudos que fazem referência às moléculas de oxLDL circulante, como partículas de LDL que sofrem pouca oxidação, tornando-as incapazes de serem reconhecida pelos receptores scavenger, sendo estas chamadas de oxLDL minimamente modificada (MILLER et al., 3003).

Apesar de ainda não está totalmente claro como e quando a LDL é oxidado no organismo, vários trabalhos mostram que o nível de oxLDL no plasma é um importante marcador preditivo para a ocorrência da aterosclerose (FRALEY; TSIMIKAS, 2006; HOLVOET et al., 2008; ISHIGAKI, 2009; ITABE et al., 2011; ITABE; UEDA, 2007). Para compreender o papel da oxLDL na aterogênese, diversos estudos têm dado bastante importância em esclarecer o comportamento de oxLDL in vivo durante a aterogênese, particularmente como a oxLDL é formada, como ela se move em torno dos tecidos e como ela é metabolizada (STOCKER; KEANEY, 2003). O que os trabalhos têm mostrado é que os níveis de oxLDL aumenta no plasma de pacientes com várias condições patológicas, incluindo doenças cardiovasculares e infarto cerebral (EHARA et al., 2001; NARUKO et al., 2006; TSIMIKAS et al., 2007; UNO et al., 2003).

Um dos pontos mais importantes e considerado hoje como um dos maiores elos para a compreensão da gênese da doença aterosclerótica foi o melhor entendimento do 
papel do sistema imunológico após a modificação da lipoproteína de baixa densidade (mLDL - modified Low Density Lipoprotein) (FAN; WATANABE, 2003; HANSSON et al., 2006; HANSSON; LIBBY, 2006; HOLVOET et al., 1998), em especial das modificadas por oxidação. 0 papel da mLDL na aterosclerose tem sido bastante investigado e gerado excelentes conhecimentos sobre a evolução patológica (HANSSON et al., 2006; HANSSON; LIBBY, 2006).

Com o foco sobre as partículas de oxLDL e a resposta imune gerada sobre elas, muitos estudos tentam correlacionar modificações oxidativas com a produção de autoanticorpos e a evolução da lesão (DAMASCENO et al., 2001; GIDLUND et al., 1996) . Outros trabalhos tem mostrado a presença de oxLDL circulante e que seus altos níveis estão correlacionados com a progressão da aterosclerose, porém deixa vago a real função dos auto-anticorpos anti-oxLDL (ANDICAN et al., 2008; VAN TITS et al., 2003).

A maior dificuldade desse tipo de estudo está na grande variedade de moléculas que pode ser gerada por essas modificações na LDL (STOCKER; KEANEY Jr., 2003). Dados controversos na literatura quanto à presença de oxLDL provavelmente se deviam a esse fato. Alguns autores sugeriram que oxLDL não era detectável na circulação porque era rapidamente removida por receptores scavenger no sinusóide hepático (JANSEN et al., 1995; WITZTUM, 1993), enquanto outros trabalhos mostraram a presença de oxLDL no plasma e fizeram correlação positiva entre níveis de oxLDL circulante e a progressão da aterosclerose (STOCKER; KEANEY Jr., 2003; VAN TITS et al., 2003). Muitas dessas discrepâncias vinham da dificuldade em se mensurar a multiplicidade de partículas de oxLDL envolvida no desenvolvimento da aterosclerose. 


\subsection{Os níveis plasmáticos de oxLDL em pacientes com várias condições patológicas}

Há diversos outros fatores que são estudados para entender a aterogênese. Entre eles, tem o risco cardiovascular associado a mulheres obesas e menopausadas. Kassi et al. (2009) verificaram que os níveis de oxLDL estavam elevados em ambas as condições e que os níveis de anticorpos anti-oxLDL estavam diminuídos. Procurando-se entender o papel do tabagismo nesse tipo de paciente, analisando os três aspectos conjuntamente, ou seja, mulheres obesas, menopausadas e fumantes, verificou-se que a obesidade associada à menopausa estava mais envolvida na oxidação da LDL, sendo melhor preditor para aterosclerose que o tabagismo.

Em pacientes com hipertensão arterial, a oxLDL foi detectada no plasma destes pacientes, porém, durante o tratamento anti-hipertensivo houve alteração nos níveis de oxLDL circulante. Brandão et al. (2010), em estudo enfocando o tratamento antihipertensivo, verificaram que com o controle da hipertensão houve aumento dos níveis de anticorpos anti-oxLDL e diminuição de oxLDL.

Em estudo com pacientes em situações clínicas estáveis, tais como hipertensão arterial controlada e também com pacientes instáveis, como síndrome coronária aguda, o comportamento desses anticorpos diferiu de forma significativa. Santos et al. (2009) observaram que, em pacientes com hipertensão controlada e com menor risco cardiovascular, os títulos de anticorpos anti-oxLDL estavam elevados quando comparados com aqueles observados em pacientes com síndrome coronária aguda, e concluem que a elevação dos níveis circulantes desses anticorpos poderia ser fator protetor diante de aterosclerose. Já em outro estudo, Soltesz et al. (2007) observaram que pacientes com síndrome coronária aguda apresentavam maiores títulos de anticorpos anti-oxLDL quando comparados a pacientes estáveis, porém sem diferença estatística. Esses autores concluem que a oxLDL é um fator importante na análise de pacientes com doença coronária aguda, não podendo especificar se anticorpos elevados em ambos os grupos têm alguma participação na doença aterosclerótica.

Em referência ao tabagismo, o efeito do fumo ainda não está totalmente esclarecido no tocante à interação entre esse fator de risco e a oxidação das LDL. Zaratin et al. (2002) discutem, em estudo realizado com indivíduos normolipêmicos e fumantes, que os imunocomplexos são marcadores da aterosclerose e podem modificar os títulos de anticorpos anti-oxLDL. Além disso, os autores confirmam que os títulos de anticorpos 
anti-oxLDL podem variar ao longo do estabelecimento da aterosclerose, colaborando com a formação e a estabilidade das placas.

Outro tipo de estudo que torna-se importante citar é o que envolve pacientes diabéticos, uma doença cuja evolução se associa a alto índice de complicações cardiovasculares ateroscleróticas. Essas complicações decorrem de alterações metabólicas crônicas, tais como estresse oxidativo induzido pela hiperglicemia, que leva à formação de oxLDL durante toda a evolução da doença (GRADINARU et al., 2013; YANJUN et al., 2014). Quando foram analisados pacientes diabéticos com aterosclerose, relacionando anticorpos e a rigidez vascular, verificou-se que os níveis de IgG antioxLDL eram importantes em determinar o grau de aterosclerose nesses pacientes. Observou-se que pacientes com pior padrão de rigidez vascular, também estavam com níveis de IgG anti-oxLDL bastante elevado (PIARULLI et al., 2005).

Em estudos com indivíduos saudáveis, nota-se uma relação inversa entre níveis de oxLDL e anticorpos anti-oxLDL, ou seja, foram observados baixos níveis de oxLDL e elevados níveis de anticorpos. Dessa forma, sugere-se que em indivíduos sadios e, portanto, com baixo risco coronário, os altos níveis plasmáticos de anticorpos antioxLDL podem ser protetores na prevenção da aterosclerose, corroborando com o conhecimento de que oxLDL esteja associado com a ocorrência da aterosclerose (FUKUMOTO et al., 2000; SHOJI et al., 2000). 


\subsection{Os Métodos de detecção de oxLDL}

Com o fato das moléculas de oxLDL serem captadas pelos macrófagos, acreditavase inicialmente que essas partículas estivessem ausente no sangue. Devido a isso, ouve grande desenvolvimento na produção de anticorpos monoclonais anti-oxLDL e ELISA (Enzyme-Linked Immunosorbent Assay) bastante sensíveis para mensurar quantidades muito pequenas de oxLDL circulante (ITABE et al., 1996; KOHNO et al., 2000).

Apesar de hoje em dia, altos níveis de oxLDL no plasma serem reconhecidos como importantes marcadores de risco para eventos cardiovasculares, como a ocorrência da aterosclerose, ensaios simples e baratos para determinação de LDL oxidada não são encontrados disponíveis para utilização na rotina médica.

Atualmente existem várias formas de determinar oxLDL no sangue pelo método de ELISA empregando anticorpos monoclonais e policlonais, capazes de detectar pequenas frações de oxLDL (ITABE; UEDA, 2007; SAKURAI et al., 2013). Apesar de haver uma ampla diferença nos procedimentos de ELISA utilizados para determinar oxLDL, desde as partículas alvo para serem detectadas, até a avidez que os métodos proporcionam, não há muita mudança nos procedimentos que levem a uma melhor aplicabilidade na rotina para diagnóstico. Por apresentarem algumas características bastante vantajosas, como sensibilidade e especificidade, esses procedimentos tornaram-se comumente utilizados e atualmente há diferentes kits comerciais. Além disso, esses métodos continuam sendo o padrão ouro para determinar oxLDL, visto na ampla maioria dos trabalhas publicados. É importante frisar que os princípios destes métodos são bem conhecidos e a manipulação das amostras não é complicada. No entanto, eles requerem procedimentos trabalhosos e demorados, além de aparelhos caros. Devido a isso, novas abordagens com procedimentos simples, de baixo custo e fácil portabilidade, serão muito importantes para utilização na rotina médica.

Há também outros métodos alternativos para detecção de partículas de oxLDL, como o emprego de anticorpos anti-oxLDL conjugados a nanopartículas de ouro com detecção por cromatografia líquida acoplada à espectrometria de massas (LC-MS Liquid chromatography-mass spectrometry) (HINTERWIRTH et al., 2013; OBAMA et al., 2007). Além desses, existem trabalhos que mostram métodos para mensurar oxLDL através da absorvância óptica do dieno conjugado em peróxidos de lipídios ou os seus derivados de álcool; a medição de substâncias reativas de ácido tiobarbitúrico (TBARS - 
Triobarbituric Acid Reactive Substances), incluindo hidroperóxidos lipídicos, aldeídos e álcoois (STOCKER; KEANEY Jr., 2003). Esses trabalhos podem exercer importante função na pesquisa, porém são inadequados nas aplicações em diagnósticos de rotina, pois são complexos e exigem profissionais bastante capacitados, além de ser acoplados a equipamentos caros, requerendo assim, uma estrutura laboratorial de alto padrão.

Mais recentemente, tem sido desenvolvido sensores para detecção de oxLDL e LDL não oxidada usando eletrodo de nanotubo de carbono. As moléculas de carbono com uma nanoestrutura cilíndrica possuem propriedades que são de altíssimo valor no campo da nanotecnologia, eletrônica, óptica e outros campos tecnológicos da ciência dos materiais. Porém os resultados vistos nesses trabalhos, não condizem com o desenho teórico, pois se observa muitos vieses para que se consiga obter uma técnica realmente aplicável. Como exemplo, uma pergunta fundamental seria se os nanotubos conseguem detectar apenas oxLDL e LDL, já que nesse trabalho não foi utilizada nenhum controle negativo, levando a questionamentos sobre a possibilidade dos nanotubos ligarem a outras moléculas circulantes e apresentarem, desta forma, resultados falso positivos (TAKEDA et al., 2012).

Há outros estudos que apresentam uma preparação com marcadores luminescentes com base em partículas de sílica que incorporam európio para conjugar com anticorpos anti-oxLDL, objetivando investigar a capacidade de luminescência após a formação do complexo antígeno (oxLDL) anticorpo (anti-oxLDL), utilizando reação enzima-substrato (LOURENÇO et al., 2013). Como acontece com os demais trabalhos supracitados, essa técnica tem requerido bastante tempo para obter um resultado mensurável, além de mostrar bastante complexidade.

Esses novos trabalhos tem ampliado ainda mais a complexidade e, por conseguinte, distanciado da possibilidade real de aplicação de forma simples e acessível para a população de modo geral. Devido a isso, torna-se necessário desenvolver técnicas que sejam comprovadamente eficientes na aplicabilidade, não apenas trabalhos que mostrem mudanças para obter resultados que técnicas como ELISA já mostram com bastante eficácia. 


\subsection{Biossensor}

Os biossensores podem oferecer características vantajosas em relação às ferramentas de diagnóstico como o método ELISA, pois além da alta sensibilidade e seletividade, carregam em si simplicidade, rapidez, baixo custo, portabilidade e viabilidade de automação (MALHOTRA; CHAUBEY; SINGH, 2006; MURPHY, 2006; YUAN et al., 2009; ZHAO; JU, 2006).

Os biossensores são dispositivos bio-eletrônicos compostos por duas partes, uma biológica (sensora) e outra eletrônica (transdutora), que acopladas conjuntamente são capazes de detectar espécies químicas ou biológicas qualitativa e/ou quantitativamente, imediatamente ao reconhecimento do analito. Utilizando-se diferentes biorreceptores podem ser produzidos biossensores baseados nas interações anticorpo-antígeno, ácidos nucleicos, enzimáticas ou celulares (microorganismos). De acordo com o transdutor utilizado, o biossensor pode ser classificado como óptico (luminescência, absorção, ressonância de plasmons de superfície, etc.), eletroquímico ou detector de massa (como térmicos e piezoelétricos). Diferentes tipos de transdutores têm sido utilizados em diagnóstico, entre eles, os amperométricos, os de microbalança de cristal de quartzo (QCM - Quartzo Crystal Microbalance) e os ópticos, cuja tecnologia mais utilizada é a ressonância de plásmons de superfície (SPR - Surface Plasmon Resonance) (CABRALMIRANDA et al., 2013; CUNNINGHAM, 2008; DUTRA; MACIEL NETO; FONTANA, 2001; DUTRA et al., 1999).

A fixação e a manutenção de imunocompostos sobre a superfície sensora constituem etapas fundamentais no desempenho dos biossensores. Têm sido desenvolvidos diferentes processos de imobilização de proteínas fazendo o uso de monocamadas auto-organizadas (SAMs - Self-Assembled Monolayers). A fim de construir um biosensor, o elemento de reconhecimento é imobilizado em um eletrodo de trabalho. Existem diferentes opções para avaliar o evento de reconhecimento na superfície do sensor, além da simples detecção da impedância total nas frequências selecionadas, podendo analisar as mudanças na capacitância do eletrodo ou resistência. A montagem do biossensor requer um maior aprofundamento na literatura e habilidade criativa para que o biossensor possa demonstrar características como praticidade e acessibilidade de aplicação. 
O desenvolvimento de imunosensores (biossensores baseados nas interações antígeno-anticorpo) tem chamado bastante atenção pela possibilidade real de aplicação por exibir várias características importantes, entre elas a utilização de anticorpos previamente caracterizados (CABRAL-MIRANDA et al., 2013), embora existam duas questões que dificultam o desempenho destes dispositivos. Uma dificuldade muito comum consiste em assegurar, durante a montagem do imunossensor, que os sítios de ligação aos antígenos (Fab - fragment antigen binding) dos anticorpos estejam adequadamente expostos/livres para captação dos antígenos. Muitos trabalhos relatam uma ligação aleatória de anticorpos na plataforma de transdução de sinais, dificultado os fragmentos Fabs manterem-se expostos para ligação ao antígeno. Para resolver este problema, vários autores relataram sistemas químicos complexos para garantir a ligação do anticorpo ao suporte sólido de forma a garantir a orientação correta, ou seja, a região cristalizada do anticorpo ( $\mathrm{Fc}$ - fragment crystallizable) sobre o transdutor de sinal e a região variável/Fab em condições de capturar os antígenos (CHU et al., 2006; HAO, et al., 2009; LIU et al., 2011; TSAI; LIN, 2005; ZHANG; GRÜNER; ZHAO, 2013), mas nestes casos as diversas reações envolvidas transformam-se em um processo bastante complexo e dispendioso. Além disso, a eficácia de cada etapa de modificação química é desconhecida, pelo que estes processos podem não ser tão eficazes como seria de esperar na abordagem teórica. A outra dificuldade importante é a obtenção de uma resposta específica para o antígeno, como exemplo, com uso de anticorpos monoclonais para trazer uma abordagem bem sucedida e obter uma resposta bastante específica ao antígeno alvo (CHEN et al., 2003; LIPMAN et al., 2005; LIU et al., 2011; SAERENS et al., 2008).

O conhecimento da estrutura básica do anticorpo tem conduzido ao desenvolvimento de novas tecnologias com o objetivo de mimetizá-lo, como as características polipeptídicas compostas de cadeias leves e pesadas com regiões cristalizadas ou variáveis. Nas regiões cristalizadas encontram-se as porções terminais carboxílicas $(-\mathrm{COOH})$ das proteínas, enquanto que nas regiões variáveis, encontram-se as porções terminais amina $\left(-\mathrm{NH}_{2}\right)$, onde estão os sítios de ligação ao antígeno e principal componente de interesse em mimetizá-lo para utilização em diagnósticos clínicos. As características mais atrativas dos anticorpos estão no alto grau de afinidade e especificidade que uma molécula tem para um antígeno alvo, justificando sua intensa 
aplicação em várias áreas científicas e médicas (LIPMAN et al., 2005; MADIGAN et al., 2012).

Mas o grande uso de anticorpos é possível apenas porque processos eficientes para preparar tais materiais biológicos têm sido encontrados. Entre os mais importantes está a trabalho de Köhler e Milstein (1975), os quais descobriram a forma de produção de anticorpos monoclonais utilizando a técnica de imortalização celular, através da fusão de esplenócitos produtores de anticorpos, com células de mieloma, células plasmocitárias cancerígenas. Mantendo desta forma, a característica do esplenócito produtor de anticorpos, com a característica de imortalidade que as células cancerígenas proporcionam, resultando em híbridos de células, ou hibridomas, formadoras de anticorpos e linhas celulares de replicação contínua (KÖHLER; MILSTEIN, 1975).

Todos os processos de produção de anticorpos naturais são, no entanto, bastante complexos e caros, além de exigir pessoal altamente treinado, tratamento especial e condições de armazenamento, instalações e equipamentos complexos e enormes burocracias para garantir que todas as atividades atendam às diretrizes ética na utilização de animais em laboratório. No geral, estas desvantagens têm guiado a pesquisa para novas vias sintéticas de obtenção de anticorpo, principalmente para utilização em diagnósticos. 
Figura 1 - Princípios da construção dos Biossensores

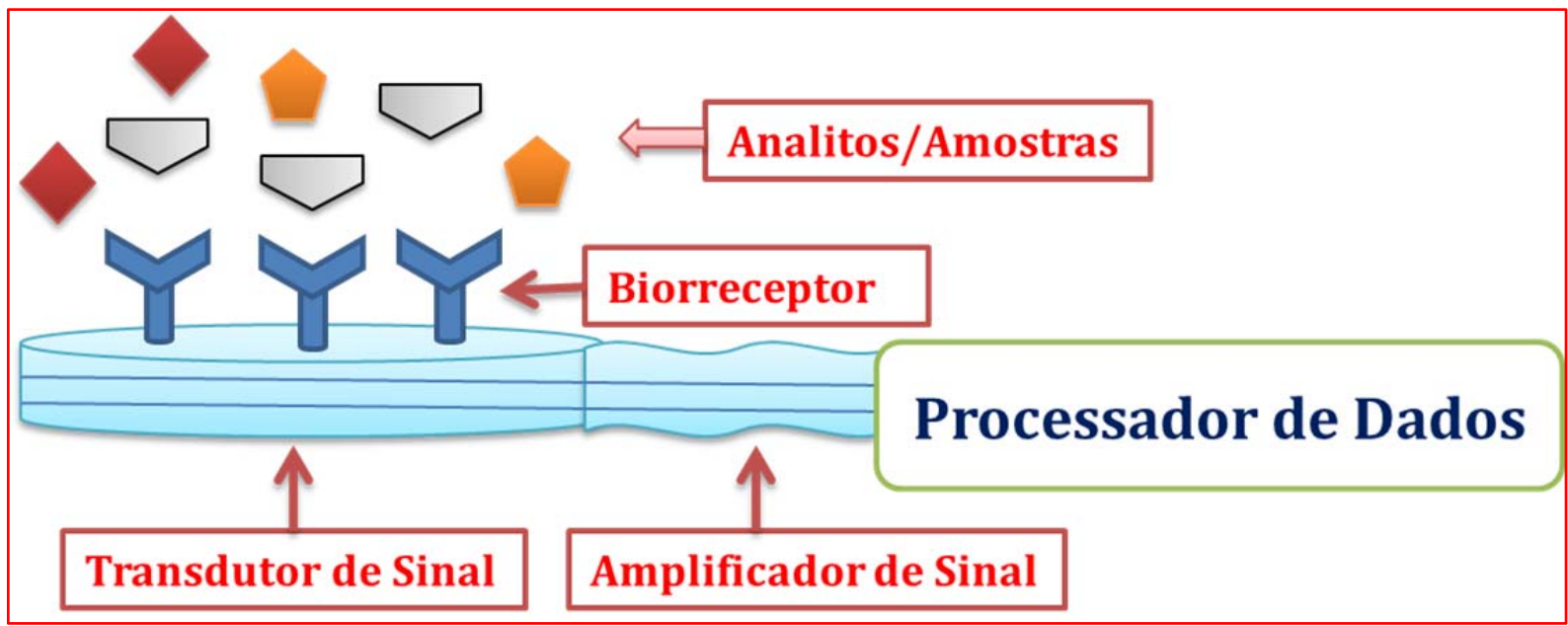

A figura mostra os componentes básicos para contrução dos biossensores, formados por compostos biológicos (Biorreceptor), como anticorpos/proteínas, fragmentos de DNA, enzimas ou até macerado de célula (microorganismos), que são utilizados para detectar as amostras desejadas (Analitos). Os Biorreceptores são imobilizados sobre uma plataforma transdutora (Transdutor de Sinal), que pode ser óptica (luminescência, ressonância de plasmons de superfície, etc.), eletroquímica ou detectora de massa (como térmicos e piezoelétricos). Para que os dados sejam mensuráveis, há a necessidade de um amplificador de sinal obtido pelo Transdutor, que encaminhará para o Processador de Dados, tornando assim, os resultados passíveis de análises. 


\subsection{Polímeros Impressos Molecularmente}

A via de síntese para a obtenção de anticorpo sintético de maior sucesso faz uso da tecnologia de impressão molecular (Molecular Imprinting Polymer - MIP) (TURNER et al., 2006; VASAPOLLO et al., 2011), utilizando uma abordagem sintética viável para a concepção de materiais de reconhecimento molecular, capazes de imitar as entidades de reconhecimento natural, tais como as interações antígeno-anticorpo. A tecnologia de impressão molecular (MIP) é uma técnica para desenvolver artificialmente as regiões dos anticorpos que são receptoras ao antígeno com boa seletividade e especificidade para um determinado analito, que pode ser utilizado como material ideal em vários campos de aplicação, em especial no campo dos novos diagnósticos. Os MIPs, ou matrizes poliméricas obtidas utilizando a tecnologia de impressão, são robustos elementos de reconhecimento molecular úteis para separar e analisar amostras complexas, tais como os fluidos biológicos e amostras ambientais (BOSSI et al., 2007; POMA; TURNER; PILETSKY, 2010; VASAPOLLO et al., 2011; YE; MOSBACH, 2008).

0 primeiro trabalho que demonstrava características referentes à impressão molecular foi publicado em 1931 por Polyakov (POLYAKOV, 1931), embora tenha sido demonstrado pela primeira vez em 1972 por Wulff e Sarhan. O entusiasmo dos pesquisadores neste campo de materiais biomiméticos continua até os dias de hoje, um pouco na sequência dos grandes desenvolvimentos em nanotecnologia das últimas décadas. Basicamente, o processo de construção de um MIP recorre à formação de uma rede polimérica rígida em torno de uma molécula alvo, o antígeno. Os sítios impressos são deixados livres quando o molde sai da matriz polimérica, teoricamente correspondente ao tamanho e à forma do alvo de detecção. Apesar dos muitos anos de avanços, tendo como alvo moléculas de grande porte, tais como proteínas, a tecnologia de impressão molecular ainda é um desafio para a aplicação prática, devido ao complexo processo de mimetizar as características naturais que um anticorpo desempenha, por exemplo, como o grande potencial seletivo que este demonstra a um determinado epítopo. O tamanho, a complexidade, a flexibilidade conformacional e a baixa solubilidade das proteínas são os principais obstáculos à obtenção de um material MIP de sucesso, mas que têm vindo gradualmente sendo superado (BOSSI et al., 2012; MOREIRA et al., 2013; REDDY; SETTE, 2011; TAKEUCHI; HISHIYA, 2008; TURNER, et al. 2006; VERHEYEN et al., 2011). 
Os MIPs parecem ser a abordagem mais bem sucedida em desenho de anticorpo plástico. Consiste, principalmente, em fixar o molde em uma superfície, permitindo uma fase de pré-polimerização onde monômeros funcionais podem ligar-se à molécula molde (BOSSI et al., 2012, CHEN; XU; LI, 2011; HAYDEN et al., 2006). Em geral, a imobilização covalente de moléculas do molde na superfície de substratos sólidos oferecem algumas vantagens, pois permitem imprimir modelos que são insolúveis na mistura de prépolimerização e minimizam a agregação das moléculas molde, conduzindo assim a sítios de ligação mais homogêneos (CHEN; XU; LI, 2011).

Os materiais produzidos por impressão de superfície contêm áreas que são capazes de ligar as proteínas por meio de interações não específicas, o que por sua vez reduzem a seletividade do material para o seu composto alvo. A possibilidade de uma diferenciação química entre o sítio de ligação e a superfície circundante foi recentemente proposta para reduzir este efeito. Isto foi feito através da adição de cargas nos sítios de ligação e a polimerização da área circundante com monômeros neutros (MOREIRA et al., 2013). Os materiais biomiméticos obtidos foram chamados SPAM, os quais mostraram maior afinidade e seletividade para a proteína alvo. No entanto, há uma dificuldade comum no SPAM entre a superfície de impressão, que é o controle da espessura da camada de polímero. Quando a espessura do polímero é maior do que o tamanho do molde, medido quando ligado à superfície do receptor, o modelo a ser impresso é incapaz de sair da rede polimérica. Portanto, controlar a espessura do polímero em impressão superfície é fundamental, pois o número de sítios de ligação e a dimensão destes sitios estão diretamente correlacionados com esse recurso simples. No entanto, é uma tarefa difícil, pois os moldes de proteínas são geralmente menores do que $10 \mathrm{~nm}$, e o modelo pode ser ligado à superfície do receptor em posições diferentes, que de acordo com a conformação da proteína acima da superfície pode conduzir a diferentes requisitos de espessura de polímero dentro do mesmo material.

Para superar a dependência da espessura do polímero, o trabalho desenvolvido propõe uma camada impressa de forma invertida do anticorpo plástico, SPAM, desta vez denominada MAPS. A seção transversal do material impresso em que a proteína apresenta uma densidade mais elevada é o plano correspondente à proteína ligada covalentemente. A saída desta camada faz com que as proteínas estejam na mesma distância para o local de saída do material. Em geral, espera-se com esta nova abordagem, assegurar que todas as proteínas estejam em contato com a superfície 
exterior e capaz de sairem da matriz impressa, gerando, assim, uma alta densidade de sítios para religação ao antígeno.

\section{Figura 2 - Princípios da construção dos Polimeros Impressos Molecularmente}

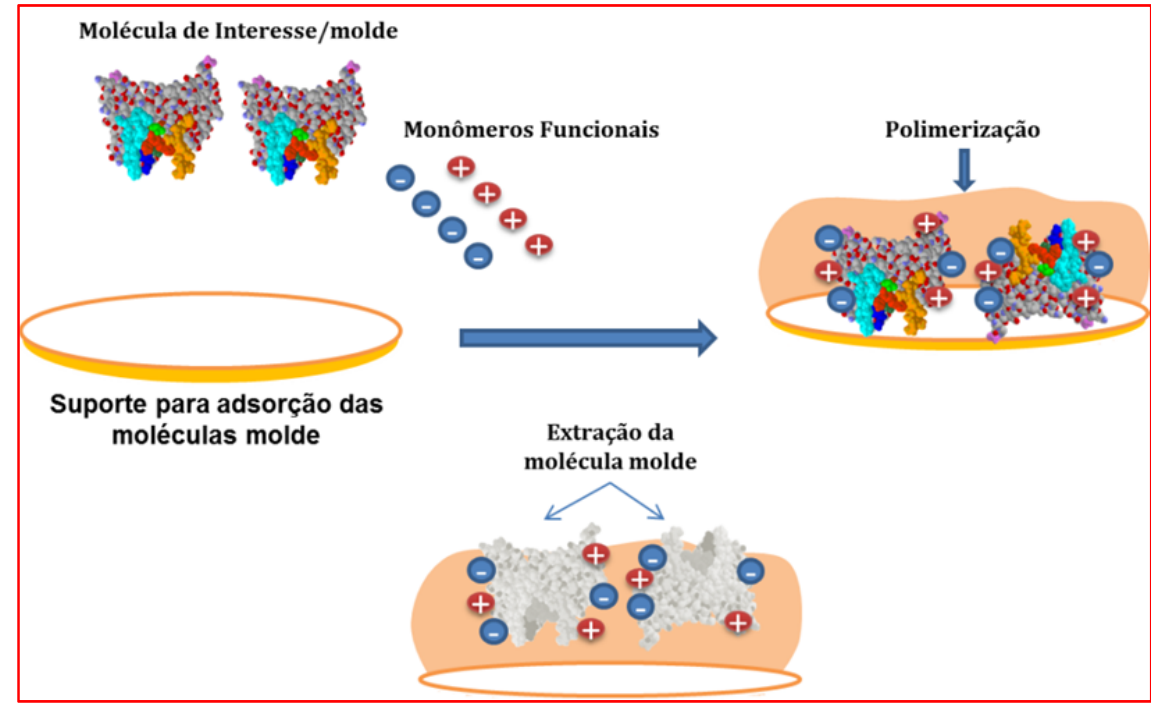

Para concepção dos polímeros impressos, ou MIPs, há a necessidade de obtenção das moléculas de interesse que serão reticuladas com monômeros funcionais sobre um suporte que geralmente servirá como plataforma de trabalho após contrução dos MIPs. Depois de funcionalizar é necessária uma rede polimérica capaz de polimerizar as moléculas de interesse de forma a manter sua estrutura natural. Posteriormente, ocorre a etapa de extração da estrutura molde sem deformação do polímero concebido, para assim, esse funcionar de maneira a detectar apenas aquelas estruturas que foram usadas para seu desenvolvimento. 


\section{OBJETIVOS}

Esse trabalho teve dois objetivos em particular. 0 primeiro foi desenvolver um novo imunossensor empregando anticorpos monoclonais anti oxLDL para gerar um biochiip com capacidade de detectar oxLDL circulante de forma rápida, alta especificidade e sensibilidade, assim como, possibilidade de altomação e minimização, para assim, transformá-lo em algo de fácil portabilidade. 0 segundo objetivo foi desenvolver um processo inovador para obter polímeros moleculares impressos, também chamados de anticorpos plásticos, anti oxLDL, que demonstrasse alta sensibilidade e especificidade, gerando assim, a possibilidade de ultrapassar a utilização de animais para o desenvolvimento de anticorpos com objetivos de diagnósticos. 


\section{MATERIAL E MÉTODO}

Todos os procedimentos envolvendo animais ou seres humanos foram aprovados e realizados de acordo com a Comissão de Ética em Pesquisa Envolvendo Seres Humanos do Instituto de Ciências Biomédicas da Universidade de São Paulo (CEPSHICB/USP) (Protocolo n … 1033/CEP) e da Comissão de Ética no Uso de Animais (CEUAICB/USP) (Protocolo $\mathrm{n}$ o 116; livro 02; página 119).

\subsection{Equipamentos}

Os experimentos eletroquímicos foram realizados em um potenciostato/galvanostato da Metrohm Autolab, modelo PGSTAT302N (Figura 3A), onde está contido o módulo de impedância (Z), e controlados pelo software NOVA. 0 eletrodo utilizado foi o Au-SPE (Figura 3C), obtido da DROPSENS (DRP-C220AT), o qual tem uma dimensão geral de $3.4 \times 1.0 \times 0.05 \mathrm{~cm}$ de comprimento x largura $\mathrm{x}$ altura, respectivamente. 0 diâmetro do eletrodo de trabalho é de $4 \mathrm{~mm}$. Esses eletrodos são descartáveis e ideais para trabalhar com micro volumes, ou por meio de imersão em solução e indicados para desenvolver ensaios e (bio)-sensores.

A célula eletroquímica é constituída por: eletrodo de trabalho e eletrodo auxiliar feitos de ouro, e eletrodo de referência feito de prata. Esses eletrodos são ligados a um conector (Figura 3B) que por sua vez está ligado ao potencióstato. 
Figura 3 - Equipamentos utilizados nos experimentos eletroquímicos.

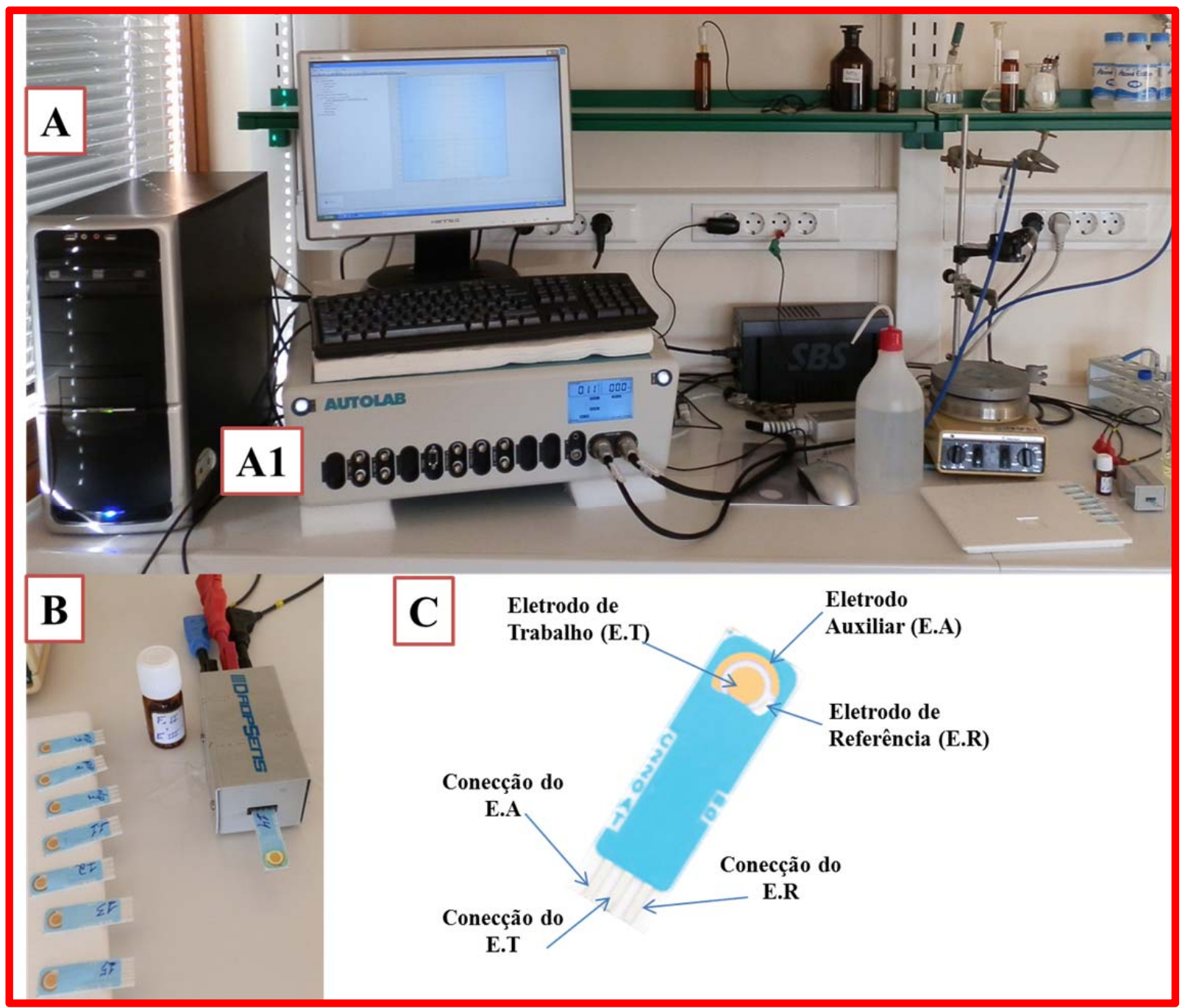

A figura mostra uma visão geral dos equipamentos utilizados nos experimentos eletroquímicos (A), em destaque o potenciostato (A1). Em (B) observa o transdutor de sinal, "Boxed Connector for ScreenPrinted Electrodes", conectado com um Au-SPE. Em (C) aparece o detalhamento da constituição de um AuSPE. 
As leituras com ondas quadradas (SWV) foram realizadas utilizando uma solução de ferro (ferri/ferro) composta com $5.0 \mathrm{mmol} \mathrm{L}^{-1}$ de $\left[\mathrm{Fe}(\mathrm{CN})_{6}\right]^{-3}$ e $5.0 \mathrm{mmol} \mathrm{L}^{-1}$ de $\left[\mathrm{Fe}(\mathrm{CN})_{6}\right]^{-4}$ preparado em PBS, pH 7. O potencial de varrimento variou entre $-0,7$ e $+0,7$ $\mathrm{V}$, que corresponde a uma frequência de $50 \mathrm{~Hz}$ e tamanho de $150 \mathrm{mV}$. Os ensaios com espectroscopia de impedância eletroquímica (EIS) foram realizados utilizando a mesma solução eletrolítica, $\left[\mathrm{Fe}(\mathrm{CN})_{6}\right]^{-3-4}$, a um potencial padrão de $0,12 \mathrm{~V}$ e potencial sinusoidal com uma amplitude de 0,01 V. O número de frequências foram iguais a 50 e logaritmicamente distribuídos ao longo de um intervalo de 0,1-100 kHz. Os dados EIS foram apresentados sob a forma de "Nyquist plots".

A análise morfológica e de superfície dos MAPS e NIM foram feitas com microscópio eletrônico de varredura (Scanning Electron Microscope -SEM) (JSM-6010LA InTouchScope). As análises de Raman foram realizadas em espectrômetro de Raman com microscopia confocal (DXR ${ }^{\mathrm{TM}}$ Raman Microscope), por focagem directa do filme de polímero fabricado em ouro. Para o traçado dos espectros usou-se uma lente de 50x.

Para a separação das amostras de LDL, foi utilizada uma ultracentrífuga Beckman, 50Ti rotor, L-8 ultracentrifuge.

Para determinação do tamanho do oxLDL e do complexo oxLDL-anticorpo foi utilizado o equipamento de dispersão dinâmica de luz (Dynamic Light Scattering-DLS), acrescentando uma pequena amostra das soluções no equipamento Avid Nano DLS.

\subsection{Obtenção e Purificação dos Anticospos Monoclonais}

Três hibridomas produtores de anticorpos monoclonais anti-oxLDL nomeados de 73, 77 e 87, previamente obtidos e caracterizados por nosso grupo, foram descongelados e cultivados em DMEM (Dulbecco's Modified Eagle's Medium) (SigmaAldrich) contendo $10 \%$ de soro fetal bovino (FCS-Fetal Calf Serum), $100 \mu \mathrm{g} / \mathrm{mL}^{-1} \mathrm{de} \mathrm{L-}$ glutamine e $50 \mu \mathrm{g} / \mathrm{mL}^{-1}$ de gentamicina. Os isotipos dos anticorpos monoclonais $(73,77$ e 87), presentes no sobrenadante foram estocados a $-20{ }^{\circ} \mathrm{C}$ até a purificação.

A purificação dos anticorpos foi feita de acordo com Gidlund et al. (1996), através da cromatografia de afinidade utilizando proteina G (Protein G Sepharose 4 Fast FlowSigma-Aldrich). Para isso, foi acrescentado $2 \mathrm{~mL}$ de proteina G para cada $500 \mathrm{~mL}$ de sobrenadante e levado a leve agitação por aproximadamente $6 \mathrm{~h}$ para que os anticorpos se ligassem às proteínas G. Após agitação, o frasco foi deixado em repouso para 
decantação. 0 sobrenadante foi retirado e a proteína $\mathrm{G}+$ anticorpos foram lavados com PBS até que a solução ficasse transparente para posteriormente acrescentar em uma espécie de seringa (coluna).

As proteínas não adsorvidas foram retiradas durante a lavagem com PBS. Os anticorpos monoclonais foram em seguida eluídos da coluna com ácido acético a 0,5M e coletadas 10 gotas do eluente em tudos de ensaios com $250 \mu \mathrm{L}$ de TRIS a $1 \mathrm{M}$ com pH 8.8 por tubo, para neutralisar o pH das amostras. A presença de proteínas (anticorpos), em cada tubo foi detectada pelo método de Bradford (1976).

Após essa etapa de purificação, juntou-se as alíquotas contendo anticospos para criar um pool com uma maior quantidade de proteínas, e, posteriormente, dialisadas em PBS durante 18 h. Após diálise, os anticorpos purificados foram analisados quanto à concentração de proteína pelo método de Lowry et al. (1951), aliquotados e estocados a $-20{ }^{\circ} \mathrm{C}$ até o uso.

\subsection{Isotipagem dos Anticorpos quanto à Classe e Subclasse de Imunoglobulinas}

Os isótipos dos anticorpos monoclonais foram determinados através de ELISA indireto, utilizando o kit de isotipagem de anticorpos de camundongos (SIGMA, Saint Louis, Missouri, USA). Para isso, uma placa de microtiluçação, high binding, de 96 poços foi sensibilizada com anticorpos de cabras anti camundongo IgG1, IgG2a, IgG2b, IgG3, IgM or IgA e deixados durante a noite a $4{ }^{\circ} \mathrm{C}$ para boa adsorção na placa. Para evitar reações inespecíficas, a placa foi bloqueada utilizando PBS-Leite a 5\% (Leite Molico, Nestle) por duas horas a $37^{\circ} \mathrm{C}$. Após o bloqueio, foi adicionado separadamente $100 \mu \mathrm{L}$ dos anticorpos 73, 77 ou 87 a $250 \mu \mathrm{g} / \mathrm{mL}^{-1}$ e incubados por uma hora a $37{ }^{\circ} \mathrm{C}$. Posteiormente, foi adicionado em todos os poços, anticorpos anti-imunoglobulina de camundongo conjugados a peroxidade (Amersham LIFE SCIENCE) diluídos 1:1000 e incubados por uma hora a $37{ }^{\circ} \mathrm{C}$, para em seguida, adicionar substrato OPD (ophenylenediamine dihydrochloride) (Sigma-Aldrich) com peróxido de hidrogénio. A reação foi parada com ácido sulfúrico $2 \mathrm{~N}$ e lida utilizando espectrofotômetro a $492 \mathrm{~nm}$. Entre todos os passos do ensaio, a placa foi lavada quatro vezes com PBS-Tween contendo 0,05\% de Tween 20 (PBS-SM-T20) e três vezes com PBS puto. 


\subsection{Obtenção e Oxidação das Lipoproteínas de Baixa Densidade}

Para obtenção de LDL in natura, amostras de sangue foram coletadas de voluntários saudáveis e de ambos os sexos. 0 sangue foi coletado em tubos vacutainer (tubos de coleta de sangue a vácuo) contendo 0,054 $\mathrm{mL}$ de anticoagulante, ácido etilenodiaminotetraacético (EDTA), para 4,5mL de volume obtido. 0 sangue de cada voluntário foi centrifugado separadamente a $1000 \mathrm{xg}$, na temperatura de $4{ }^{\circ} \mathrm{C}$ por $10 \mathrm{~m}$, e posteriormente feito um pool de plasmas. No plasma total foram adicionados $2 \mathrm{mM}$ de benzamidine, $\quad 0.5 \%$ gentamicina, $\quad 0.25 \%$ cloranfenicol, $0.5 \quad \mathrm{mM}$ PMSF (phenylmethylsulfonyl fluoride) e 0,1 unidade/mL de aprotinina, para evitar a contaminação.

A LDL $(\mathrm{d}=1.006 \pm 1.063 \mathrm{~g} / \mathrm{mL})$ foi separada por ultracentrifugação sequencial, a $100.000 \mathrm{xg}$, por $20 \mathrm{~h} \mathrm{a} 4{ }^{\circ} \mathrm{C}$. Após separação, a LDL foi dialisada por $48 \mathrm{~h}$ em PBS-EDTA

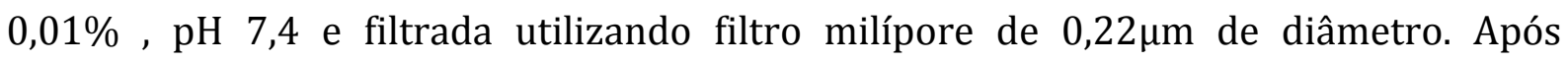
obtenção da LDL, uma alíquota foi separa para dosagem de proteínas na partícula de LDL utilizando o método de Lowry et al. (1951) e a parte maior foi armazenada a $4{ }^{\circ} \mathrm{C}$ até a utilização.

Para preparar oxLDL, a LDL na concentração de 4 a $6 \mathrm{mg} / \mathrm{mL}^{-1}$ foi incubada com sulfato de cobre $\left(\mathrm{CuSO}_{4}\right)$, numa concentração final de $20 \mu \mathrm{M}$, por $18 \mathrm{~h}$ a $37^{\circ} \mathrm{C}$. A reação foi bloqueada com adição de EDTA 1 mM (FERNVIK et al., 2004; ZARATIN et al., 2002).

\subsection{Construção do Imunossensor Utilizando os Anticorpos 73, 77 e 87}

Para construção do imunossensor, foi escolhido o chiip Au-SPE, que contém uma tinta de ouro sobre o eletrodo de trabalho, como plataforma para ligação dos anticorpos. Para ligar a região Fc do anticorpo ao eletrodo de trabalho, foi utilizado cisteamina $\left(\mathrm{C}_{9} \mathrm{H}_{13} \mathrm{~N}_{3} \mathrm{O}_{5}\right)$ a $50 \mathrm{mM}$ como SAM, pois dessa forma, ficariam aminas livres capazes de ligarem-se com as carboxilas da região Fc dos anticorpos. 0 tempo de formação da SAM foi de uma hora em temperatura ambiente. Antes da adição dos anticorpos sobre a cisteamina, estes reagiram com NHS (N-hydroxysuccinimide- $\mathrm{C}_{4} \mathrm{H}_{5} \mathrm{NO}_{3}$ ) e EDAC (N-Ethyl$\mathrm{N}$-(3-dimethylaminopropyl)-N-ethylcarbodiimide hydrochloride) a $25 \mathrm{mM}$, por 15 minutos em temperatura ambiente, para ativação das regiões carboxílicas dos anticorpos. Até então, os experimentos estavam sendo feitos com altas concentrações 
dos três anticorpos juntos, pois o objetivo seria conseguir ligar os anticorpos sobre a plataforma de ouro com cisteamina e mensurar essa ligação por ensaios eletroquímicos.

Após a ligação do anticorpo sobre a cisteamina, houve o bloqueio de possíveis espaços que a cisteamina e/ou os anticorpos não tivessem ocupados, adicionando BSA (Bovine Serum Albumin) a $0.5 \mathrm{mg} / \mathrm{mL}^{-1}$ e incubando por uma hora em temperatura ambiente. Posteriormente ao bloqueio, houve a obtenção do imunossensor em condições de testes. Então, este foi experimentado para detecta altas concentrações de oxLDL, e outros antígenos, como LDL não oxidada, mioglobina e hemoglobina, como controles negativos. Durante os testes, foram adicionados alíquotas de $10 \mu \mathrm{l}$ da amostra de oxLDL diluida em PBS numa concentração de $100 \mu \mathrm{g} / \mathrm{mL}^{-1}$, para provar a viabilidade do imunossensor às moléculas oxLDL. Após obteção dos resultados do imunossensor com oxLDL, estes foram testados com os controles negativos, seguindo a mesma metodologia aplicada com oxLDL. Todas essas etapas de modificação química sobre o eletrodo de trabalho do Au-SPE foram medidas com EIS.

\section{Figura 4 - Desenho esquemático referente ao processo de construção do imunossensor}

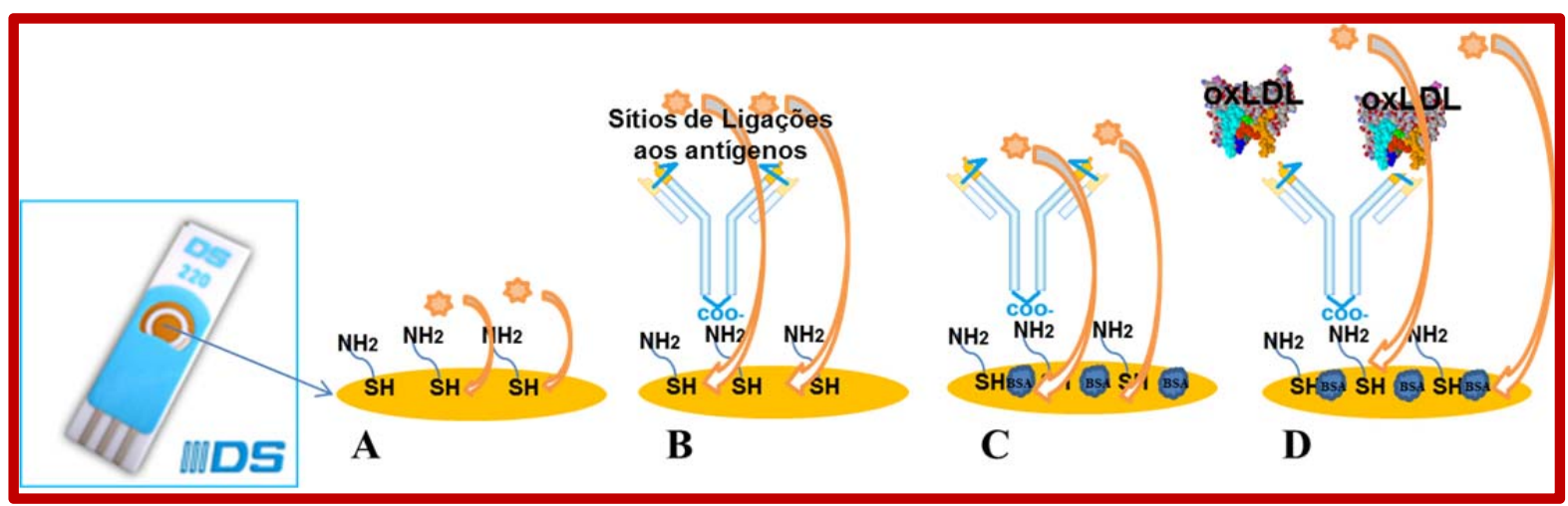

(A) 0 eletrodo de trabalho do Au-SPE contendo cisteamina com o grupo tiol ligado e as moléculas aminas expostas para ligação às regiões carboxílicas dos anticorpos; (B) uma molécula de anticorpo ligada com a região Fc sobre a cisteamina depositada no eletrodo; (C) adição de moléculas de BSA como forma de bloqueio de espaços livres contigo sobre o eletrodo de trabalho; (D) adição de oxLDL como antígeno alvo dos anticorpos/imunossensor. Em todos os passos foi realizada leitura eletroquímica utilizando Ferri/Ferro como solução eletrolítica. Figura obtida de Cabral-Miranda et al. (2014). 


\subsection{Otimização do Imunossensor anti-oxLDL}

Após os testes iniciais com o imunossensor utilizando altas concentrações de oxLDL e controles negativos, passou-se para o processo de otimização.

Os primeiros testes foram para obter uma concentração ideal dos anticorpos que fosse capaz de ocupar todo o espaço do eletrodo de trabalho e mostrasse boa resposta ao antígeno. Para isso, foi adicionado de forma crescente, sobre a camada de cisteamina, alíquotas de $10 \mu \mathrm{L}$ dos anticorpos numa concentração de $10 \mu \mathrm{g} / \mathrm{mL}^{-1}$ até atingir um ponto de saturação.

Posteriormente ocorreu os ensaios para obter o tempo mínimo que os anticorpos conseguinham ligar ao oxLDL, para em seguida obter um ponto de corte que o imunossensor poderia detectar oxLDL diluído em tampão PBS. Como aconteceu nos ensaios de obtenção da concentração de trabalho dos anticorpos, passou-se a testar o imunossensor com oxLDL em concentrações iguais de forma crescente, iniciando com $5 \mu \mathrm{g} / \mathrm{mL}^{-1}$ até alcançar um grau de saturação.

Após otimização do imunossensor com oxLDL diluído em PBS, foram feitos testes com oxLDL diluída em FCS, como forma de aproximar o uso do imunossensor com amostras reais de plasma humano. Com isso, foi diluído oxLDL em FCS puro para uma concentração final de $100 \mu \mathrm{g} / \mathrm{mL}^{-1}$; ou oxLDL em FCS diluido em tampão 1:1, 1:10, 1:100 e 1:000, para observar se o imunossensor conseguiria detectar a oxLDL em alguma dessas diluições. Foi testado também o imunossensor com FCS sem oxLDL como forma de controle negativo.

Após testar o imunossensor para detectar oxLDL diluída em FCS puro ou diluído, e obter resultados positivos em todas as formas de diluições, foi escolhido trabalhar com oxLDL diluindo diretamente no FCS puro, como forma mais próxima do real. Em seguida foi feita diluições seriadas de oxLDL diluída em FCS, com a primeira concentração de 0,5 $\mu \mathrm{g} / \mathrm{mL}^{-1}$ e aplicações seriadas de solução com oxLDL na concentração de $2,5 \mu \mathrm{g} / \mathrm{mL}^{-1}$ até alcançar o ponto de saturação.

Até o momento, todas as atepas de mensuração estavam sendo feitas com EIS. Porém, após esse momento de testes com o imunossensor, este foi submetido a outras formas de medições eletroquímicas que fossem capazes de acompanhar a montagem e os testes do imunossensor. 
Em todas as etapas de montagem do imunossensor, assim como com os testes deste com as amostras, o chiip/eletrodo era lavado com PBS e secado cuidadosamente com azoto.

\subsection{Produção dos MAPS (Materials Antibody Plastic Smart) E NIM (Non-imprinted materials)}

O material biomimético produzido foi chamado MAPS referindo-se ao inverso do nome SPAM o qual foi uma referência para desenvolver esses anticorpos plásticos. Para superar a dependência da espessura do polímero, o trabalho desenvolvido propôs uma camada impressa de forma invertida do anticorpo plástico SPAM.

A síntese dos MAPSs foi dividida em duas partes, utilizando dois Au-SPE onde apenas os eletrodos de trabalho foram modificados, deixando assim o eletrodo de referência e o eletrodo auxiliar livres para acompanhar/medir a construção e testes dos anticorpos plásticos. Sendo importante citar que um dos Au-SPE (o primeiro) foi um eletrodo reutilizado/reciclado.

Primeiramente os Au-SPEs foram lavados com etanol, depois com água deionizada (condutividade $<0,1 \mu \mathrm{S} / \mathrm{cm}$ ) e secados com azoto. Em seguida foi adicionada sobre o eletrodo de trabalho do 1ำ Au-SPE, uma camada de PVC-COOH (Carboxylated Poly (vinyl chloride)), a qual foi preparada diluindo $0.1 \mathrm{~g}$ de Cloreto de Polivinilo Carboxilado (PVC-CCOH - Fluka) + 0.12 g de o-nitrofenil octil éter (o-NPOE- Fluka) + 1.5mL de tetrahidrofurano (THF - Aldrich) deixando em agitação com barra magnética até dissolver completamente.

A camada de PVC-COOH foi incubada durante a noite em temperatura ambiente. No dia seguinte, foi adicionado uma alíquota de água por aproximadamente $30 \mathrm{~m}$ sobre a camada de PVC-COOH para hidratá-la e em seguinda houve a ativação dos grupos carboxílicos, adicionando $25 \mathrm{mM}$ de NHS (N-Hydroxysuccinimide, Fluka) por $10 \mathrm{~m}$ e em seguida com NHS + EDAC (N-(3-Dimethylaminopropyl)-N'-ethylcarbodiimide hydrochloride, Sigma) a $50 \mathrm{mM}$ por $2 \mathrm{~h}$, ambos em temperatura ambiente e ambos os reagentes preparados em água desionizada.

Após ativação dos grupos carboxílicos, foram ancoradas as moléculas de oxLDL diluídas em tampão PBS para uma concentração final de $4 \mathrm{mg} / \mathrm{mL}^{-1}$. A reação aconteceu em um período de $3 \mathrm{~h}$ em temperatura de $4{ }^{\circ} \mathrm{C}$, com posterior lavagem com PBS e 
bastante água desionizada, retirando assim as moléculas de oxLDL que não tivessem ligadas à camada de PVC-COOH.

Para bloquear os grupos carboxílicos remanescentes, foi adicionado sobre a superfície modificada com PCV-COOH+oxLDL, atilenodiamina a 0.5M preparada em água desionizada. 0 bloqueio aconteceu em um período de uma hora em temperatura ambiente. Em seguida o eletrodo foi lavado com água em abundância, secado e

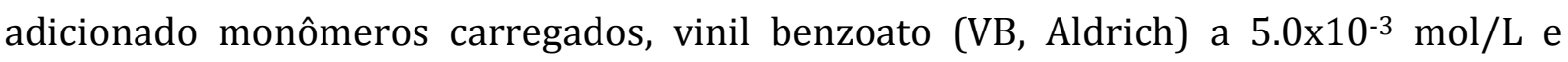
cloreto de vinil benzil trimetil amônio (VB+, Acros Organics) a $1.0 \times 10^{-2} \mathrm{~mol} / \mathrm{L}$. A incubação com os monômeros carregados ocorreu durante a noite em temperatura de $4^{\circ}$ C. No dia seguinte foi retirado o excesso de reagente e lavado cuidadosamente a superfície do sensor com água desionizada. Posteriormente, ocorreu o processo de polimerização das moléculas de oxLDL, o qual foi feito adicionando uma alíquota de aproximadamente $5 \mu \mathrm{l}$ da solução polimerizante, preparada com ácido metacrílico

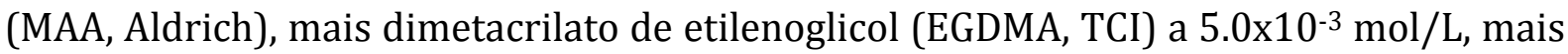
Peróxido de Benzoíla (BPO, Himedia) a 5.0×10-4 mol/L; a polimerização ocorreu em temperatura ambiente em um período de 5h. Após polimerizar, houve a ativação dos grupos carboxílicos do polímero com $25 \mathrm{mM}$ de NHS por $10 \mathrm{~m}$ e em seguida com NHS+EDAC a $50 \mathrm{mM}$ por $2 \mathrm{~h}$, ambos em temperatura ambiente. Posterior a ativação dos grupos carboxílicos do polímero, houve ligação deste ao $2^{\underline{0}}$ Au-SPE que foi paralelamente preparado para extração do polímero preparado sobre o chiip 1.

A preparação do $2^{\mathrm{o}}$ Au-SPE ocorreu inicialmente com a funcionalização do eletrodo de trabalho com grupos carboxílicos, incubando por $20 \mathrm{~h}$ com ácido

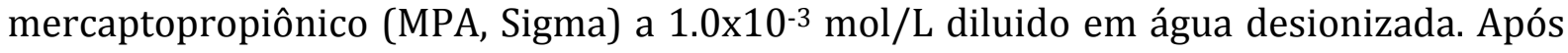
funcionalizar, os grupos carboxílicos foram ativados com $25 \mathrm{mM}$ de NHS por $10 \mathrm{~m}$ e em seguida com NHS+EDAC a $50 \mathrm{mM}$ por $2 \mathrm{~h}$.

Antes de ligar ao chiip 1, houve a adição de etilenodiamina a $0.5 \mathrm{M}$ sobre o eletrodo de trabalho do chiip 2 e incubado por $1 \mathrm{~h}$ em temperatura ambiente. A etilenodiamina serviu como agente de ligação entre os chiips 1 e 2 .

As superfícies modificadas dos Au-SPE 1 e Au-SPE 2 (eletrodos de trabalho), foram então alinhadas e mantidas unidas por $24 \mathrm{~h}$ numa câmara úmida em temperatura ambiente e, no dia seguinte, houve a separação dos chiips com a retirada do polímero com o chiip 2. 0 Au-SPE 2 foi em seguida tratado com proteinase $\mathrm{K}$ por 2 horas e lavado 
com água desionizada para assegurar que não ficaria nenhum fragmento de moléculas de oxLDL unidas ao polímero.

As superfícies dos materiais não impressos (NIMs-Non-imprinted materials), foram preparados com um protocolo semelhante, em que a adição de oxLDL e monômeros carregados foram substituídos por tampão e água.

O processo de construção dos MAPS e NIM foi acompanhado por leituras eletroquímicas EIS como forma de garantir que as modificações estavam acontecendo.

\section{Figura 5 - Desenho esquemático referente ao processo de construção do MAPS}

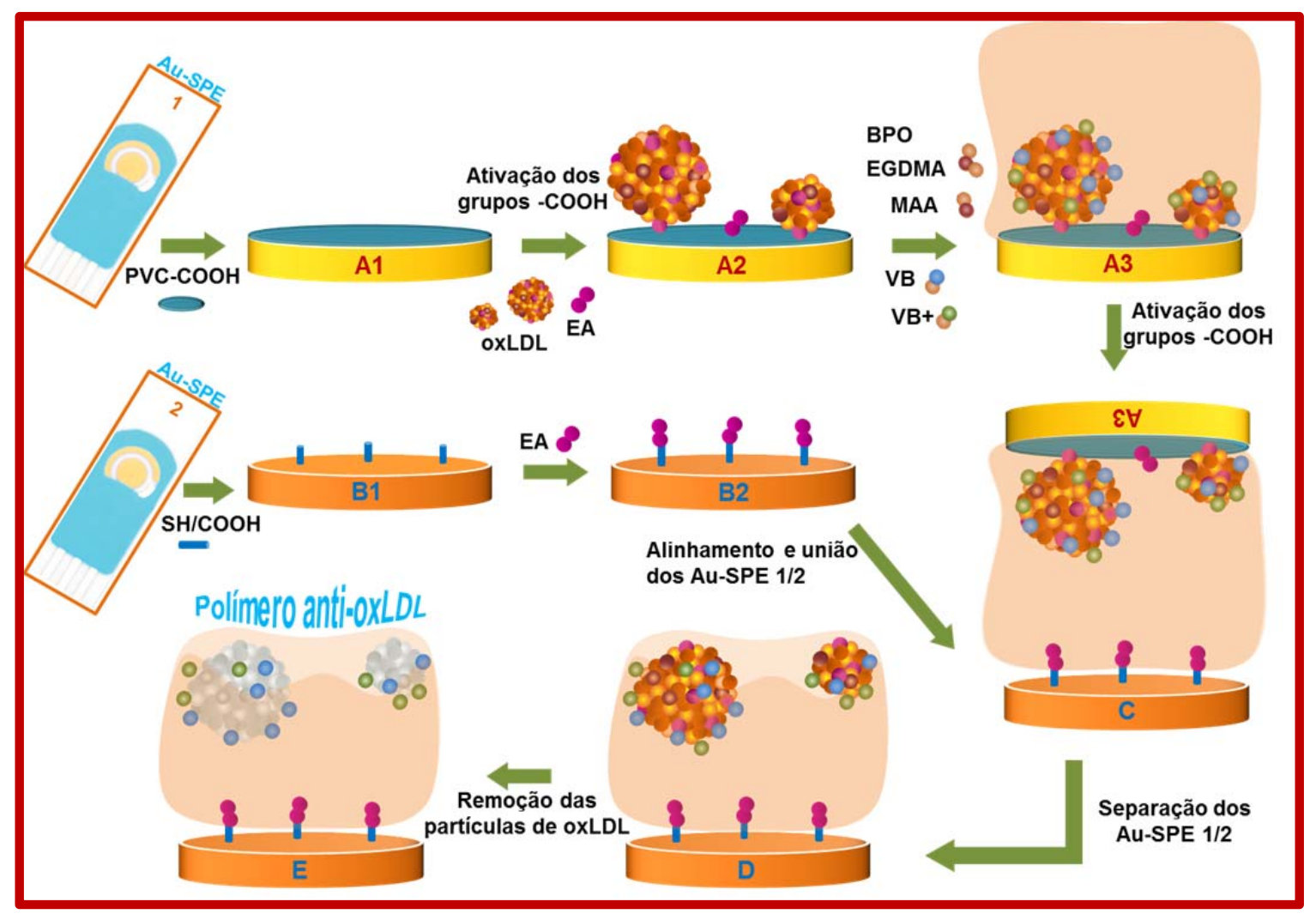

As modificações químicas do processo de contrução do MAPS ocorreram com adição de PVC carboxilado (PVC-COOH) e ativação dos grupos carboxílicos (A1); ligação das moléculas de oxLDL e bloqueio com etilenodiamina (EA) (A2); adição dos monômeros carregados vinil benzoato (VB) e cloreto de vinil benzil trimetil amônio ( $\mathrm{VB}+$ ), para ocorrer o processo de polimerização com peróxido de benzoíla (BPO), ácido metacrílico (MAA) e dimetacrilato de etilenoglicol (EGDMA) (A3). Todas essas modificações são ocorridas sobre o eletrodo de trabalho do Au-SPE-1. Paralelamente há a preparação do Au-SPE-2 com a adição de ácido mercaptopropiônico (MPA) o qual leva ao contato entre a camada de ouro (Au) do eletrodo de trabalho e o grupo tiol -SH com a formação de uma camada carboxílica (-COOH) estável na superfície exterior (B1); continua com adição do agente de ligação EA (B2) para unir os Au-SPE 1 e 2 (A3 e C). Em seguida houve a separação dos Au-SPE 1 e 2 (D) com subsequente digestão de remanescente de partículas de oxLDL (E). Figura obtida de Cabral-Miranda; Gidlund; Sales, (2014). 


\subsection{Testes e Ensaios Eletroquímicos com os MAPS e NIM}

Após obtenção dos MAPS e NIM, estes foram testados a detectar oxLDL, as quais foram as moléculas molde para construção do MAPS. Assim como, foram submetidos à detecção de moléculas de LDL não oxidada, Mioglobina e Hemoglobina como formas de controles negativos.

Com o objetivo de testar se os MAPS e NIM eram capazes de reconhecer moléculas de oxLDL em altas concentrações e diluidas em tampão, o qual não tem outras moléculas que pudessem competir com os possíveis sítios de ligação, a oxLDL foi diluída em PBS na concentração final de $50 \mu \mathrm{g} / \mathrm{mL}^{-1}$ e adicionado aproximadamente $10 \mu \mathrm{l}$ sobre os MAPS e NIM. Estes foram incubados por $1 \mathrm{~h}$ em temperatura ambiente, depois lavados com água desionizada, secados cuidadosamente com azoto e lidos com EIS. Após esses ensaios, os MAPSs foram testados com os controles negativos, seguindo o mesmo parâmetro dos testes com oxLDL.

Posteriormente aos testes iniciais dos MAPSs com oxLDL e controles negativos diluídos em PBS, passou para o processo de otimização dos ensaios. Para isso, houve mudança da solução diluente PBS por FCS, como uma forma de mimetizar a detecção de oxLDL em amostras de plasma humano; seguida com a diminuição do tempo de detecção da oxLDL. Os MAPSs também foram testados com FCS sem oxLDL, como forma de controle negativo.

Posteriormente, foi feito uma diluição seriada para obter o potencial de detecção de oxLDL pelos MAPSs. Primeiro os MAPSs foram testados com FCS puro, para em seguinda adicionarmos $10 \mu \mathrm{l}$ de FCS com oxLDL numa concentração de $2.5 \mu \mathrm{g} / \mathrm{mL}^{-1}$, incubado, lavado, secado e lido com EIS. Os passos seguintes foram com a adição sequencial de FCS com $2.5 \mu \mathrm{g} / \mathrm{mL}^{-1}$ de oxLDL, ficando assim, com 5.0, 7.5, 10.0 e 12.5 $\mu \mathrm{g} / \mathrm{mL}^{-1}$, ponto em que o MAPS não respondia mais ao oxLDL. Para confirmar a saturação, foi feito adições de solução com altas concentrações de oxLDL, especificamente $25.0 \mu \mathrm{g} / \mathrm{mL}^{-1}$ e $50.0 \mu \mathrm{g} / \mathrm{mL}^{-1}$. Durante todo o processo de construção e testes dos MAPS e NIM, estes foram lidos em EIS usando Ferri/Ferro como solução eletrolítica. Para a reutilização dos MAPS, era adicionado proteinase K para fragmentar as moléculas de oxLDL que permaneciam ligadas. 


\subsection{Visualização de Poros sobre os MAPS e NIM por microscopia eletrônica de varredura (SEM)}

Para melhor confirmação de que as moléculas de oxLDL estavam sendo ligadas a poros (sítios de ligação) formados durante o processo de polimerização, e que realmente teriam formado os poros para detectar oxLDL, os MAPS e NIM foram analisadas por microscópio eletrônico de varredura (SEM).

\subsection{Comparação de espetros Raman entre MAPS e NIM}

Tendo em vista verificar as semelhanças/diferenças químicas entre os materiais impressos e não impressos, os polímeros obtidos foram sujeitos a análise por espectroscopia de Raman, as quais foram realizadas em espectrômetro de Raman com microscopia confocal, por focagem direta do filme de polímero fabricado em ouro. Para o traçado dos espectros usou-se uma lente de 50x. 


\section{RESULTADOS}

Os resultados obtidos foram compartilhados em duas partes, sendo ambas na imunologia aplicada, em especial imunotecnologia. Primeiro houve o desenvolvimento de um imunossensor capaz de detectar oxLDL de forma rápida e com alto grau de sensibilidade e especificidade. Além deste, teve a obtenção de anticorpos plásticos anti oxLDL, que também demonstraram alta sensibilidade e capacidade seletiva com as moléculas de oxLDL. Estes conduziram a duas publicações (em anexo) na revista "Journal of Material Chemistry B", uma revista da Sociedade Real Inglesa de Química, que tem importante tradição em publicações e, por conseguinte, um alto fator de impacto.

\subsection{Peso e Tamanho das Partículas de oxLDL e do Complexo oxLDL-Anticorpos por DLS}

A distribuição do tamanho das partículas de LDL oxidada foi determinada por dispersão dinâmica de luz (DLS). Isto foi feito pela adição de uma gota de solução contendo $1 \mathrm{mg} / \mathrm{mL}^{-1}$ em uma lâmida própria do equipamento Avid Nano DLS. As partículas de oxLDL exibiram nanoestruturas com tamanho médio de 67,7 nm e com desvio padrão de 65,6 nm. A média do peso molecular das partículas de oxLDL foi de $85.013,13 \mathrm{kDa}$, correspondente a uma polidispersão de 0,94\%.

Em relação ao complexo antígeno (oxLDL)-anticorpo (anti-oxLDL), este demonstrou tamanho médio de $208,9 \mathrm{~nm}$, com um desvio padrão de 130,1 nm. 0 peso molecular do complexo foi de $440162,20 \mathrm{kDa}$, correspondente a uma polidispersão de $0,39 \%$.

\subsection{Isótipos dos Anticorpos anti-oxLDL por ELISA Indireto}

Os isótipos dos anticorpos analisados por ELISA indireto, utilizando o kit de isotipagem de anticorpos de camundongos (SIGMA, Saint Louis, Missouri, USA), demonstraram pertencer todos à classe de imunoglobulina IgG e subclasse IgG1, como mostra a figura 6 abaixo. 
Figura 6 - Isotipagem dos anticorpos anti-oxLDL.

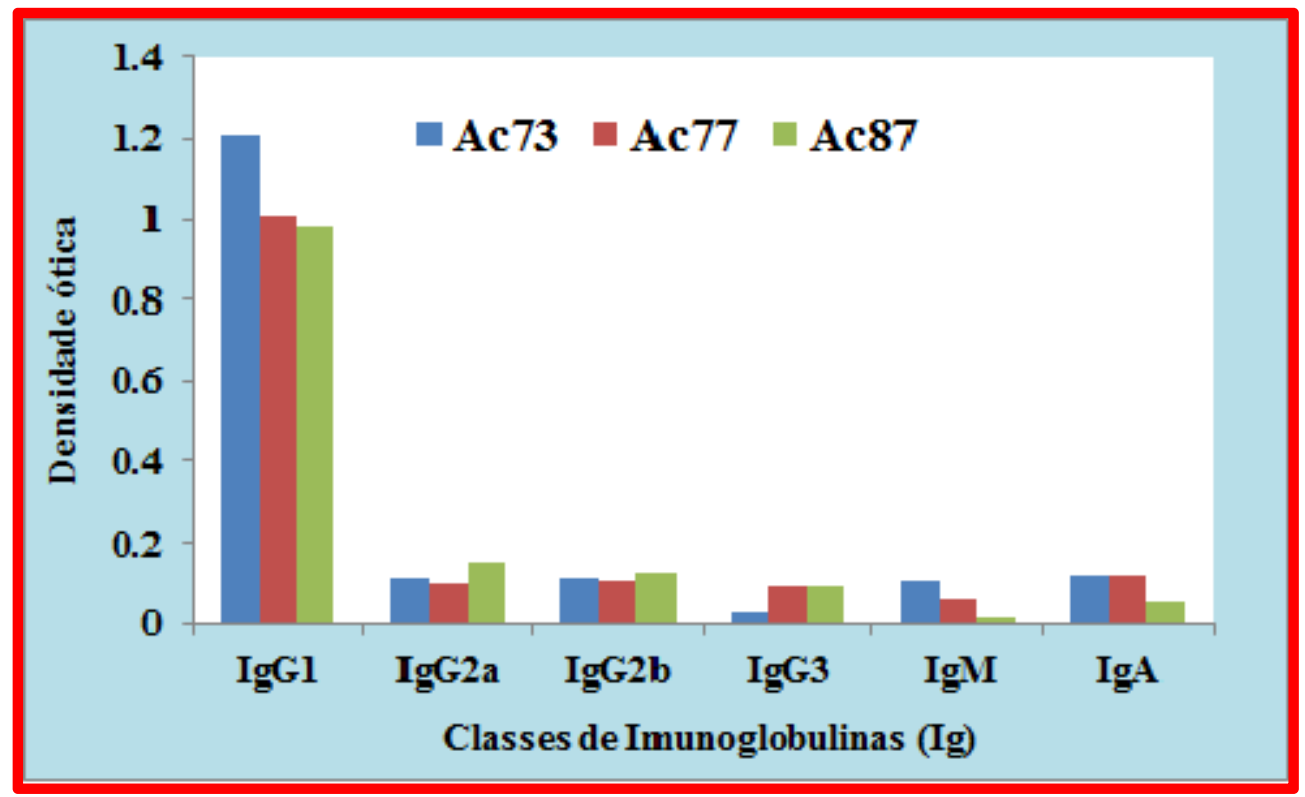

Cada coluna, azul, vermelha ou verde, representa uma linha da placa de ELISA (A, B e C), as quais foram adicionados os anticorpos 73, 77 ou 87 respectivamente, após sensibilizar os poços com os anticorpos anti-camundongos, IgG1, IgG2a, IgG2b, IgG3, IgM ou IgA.

\subsection{Construção do Imunossensor}

Para desenvolver um imunossensor que obtivesse alguns avanços no diagnóstico padrão de oxLDL, assim como, melhorar o modo de criação dos imunossensores vistos na literatura, seria necessário primeiramente de uma SAM simples, rápida e capaz de ligar os anticorpos nas regiões Fc, para poder deixar os sítios de ligação aos antígenos livres. Para isso, o desenho teórico deste imunossensor usou apenas cisteamina como SAM, pois esta seria capaz de ligar-se ao eletrodo de trabalho do Au-SPE de forma a deixar partículas de aminas livres para ligarem às regiões carboxílicas dos anticorpos. Nesta parte da montagem ocorreu como previsto, ou seja, foi possível detectar através de ensaios eletroquímicos EIS a ligação da cisteamina sobre o eletrodo. Porém, ao adicionar os anticorpos sobre o eletrodo+cisteamina, os mesmos não ligaram às aminas. Devido a isso, foi necessário ativar as regiões carboxílicas dos anticorpos sem desnaturálos, pois poderia ser esse o problema da não ligação dos anticorpos à cisteamina. Para isso, foi utilizado NHS+EDAC as quais tem reconhecida capacidade para ativação de grupos ácidos carboxílicos, sendo assim uma ferramenta poderosa e versátil para ligação de peptídeos e/ou proteínas, e preparação de sondas biomoleculares, através de imobilização de macromoléculas para o desenvolvimento de métodos de detecção e de 
análise na biologia molecular (BERTOK et al., 2013; GOODING; CIAMPI, 2011; GUO et al., 2004; JIANG et al., 2004; NGUNJIRI et al., 2013). Após ativação das regiões carboxílicas dos anticorpos, estes foram capazes de ligar às aminas sobre o eletrodo de trabalho de forma perceptível ao EIS. Após ligação dos anticorpos com cisteamina, houve o bloqueio dos possíveis sítios livres que os anticorpos e/ou cisteamina não tivessem ocupados. Foi perceptível por EIS que durante o processo de bloqueio algumas vezes o BSA (bloqueador) ligava-se a algumas regiões livres do eletrodo de trabalho. Após o bloqueio, o imunossensor foi testado com altas concentrações de oxLDL, o qual demonstrou bons resultados, com capacidade de detectar oxLDL diluído em PBS.

\subsection{Estudo da Seletividade do Imunossensor}

Após os testes com o imunossensor demonstrarem resultados positivos para detectar oxLDL diluído em PBS, este foi submetido a ensaios para detecção de LDL não oxidada, mioglobina e hemoglobina, como controles negativos, também diluídos em PBS. Todos os testes com controles negativos não alteraram a resistência do imunossensor perceptível por EIS, ou seja, o imunossensor anti-oxLDL foi capaz de responder positivamente ao oxLDL e incapaz de responder aos controles negativos, como mostra as figura 7 abaixo. 
Figura 7 - Testes da seletividade do imunossensor utilizando (A) mioglobina, (B) LDL não oxidada e (C) hemoglobina, como controles negativos.

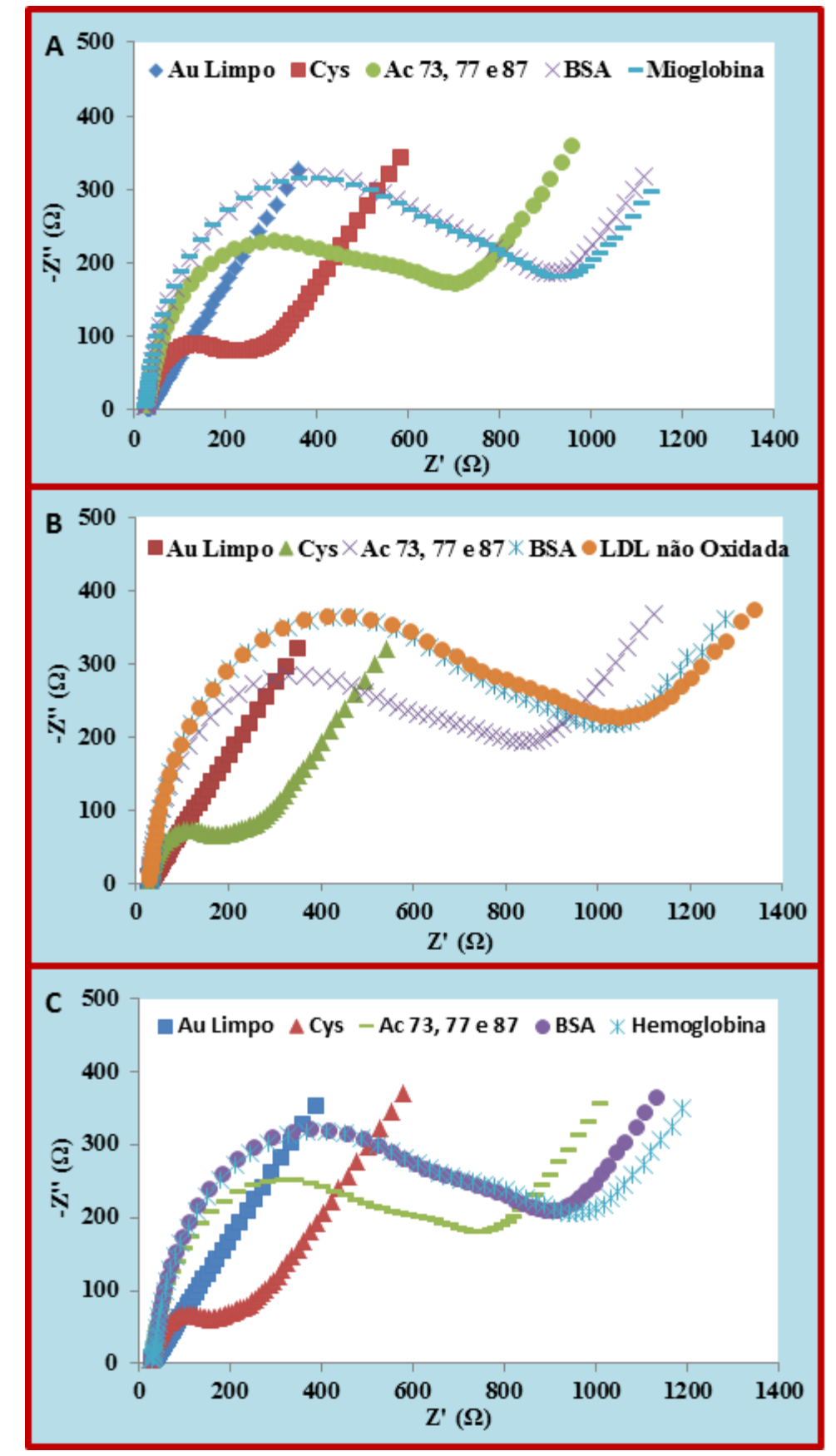

Obseravando as figuras acima A, B e C, nota-se que há mudança nas sucessivas modificações químicas onde os eletrodos alteraram suas características elétricas, com a adição de cisteamina (Cys) sobre o ouro limpo, posteriormente com a ligação dos anticorpos e o bloqueio com BSA. Porém, ao adicionar mioglobina (A), LDL não oxidada (B) e hemoglobina (C), os imunossensores não alteraram suas resistências sobre o eletrodo de trabalho, como mostram as regiões de semicírculo estável após o bloqueio. Isso mostra que os imunossensores não respondem aos controles negativos. Figura obtida de Cabral-Miranda et al. (2014). 


\subsection{Ensaios Eletroquímicos com o Imunossensor Utilizando os Anticorpos Monoclonais Separadamente}

Após o imunossensor ser construido utilizando um pool dos anticorpos em alta concentração, este foi remontado utilizando os anticorpos $(73,77$ ou 87) separadamente para testar se todos estariam viáveis para detectar oxLDL após a construção do imunossensor. Mas antes dos testes com os anticorpos separadamente, foi obtido a melhor concentração dos anticorpos que fossem capazes de suprir todo o espaço do eletrodo de trabalho do Au-SPE que seria usado no decorrer dos experimentos. 0 resultado obtido demonstrou muita oscilação no grau de concentração dos anticorpos, perceptível por EIS. Então, utilizando conhecimentos obtidos durante a construção de outro imunossensor (CABRAL-MIRANDA et al., 2013) foi estabelecido a concentração de $50 \mu \mathrm{g} / \mathrm{mL}^{-1}$ como padrão para construção do imunossensor, com os anticorpos separadamente ou juntos. Em seguinta, foi montado o imunossensor utilizando os anticorpos separadamente e os resultados mostraram que todos os anticorpos estavam viáveis para detectar oxLDL, mesmo que em grau de resistência/detecção diferente (figura 8). 
Figura 8 - Resposta eletroquímica EIS do imunossensor, utilizando os anticorpos (Ac) 73 (A), Ac73 (B) ou Ac87 (C) separadamente.

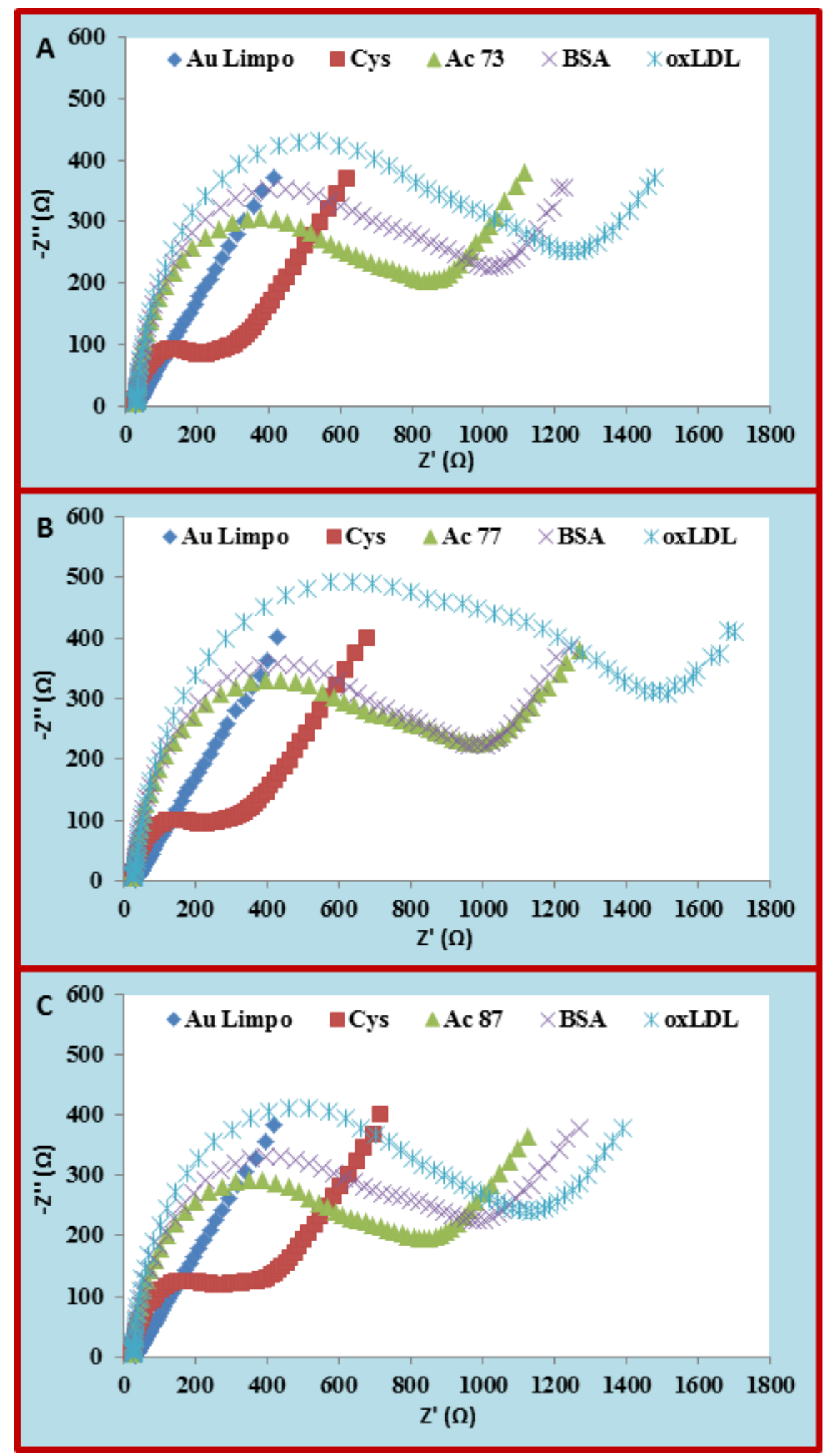

Ao montar o imunossensor com os anticorpos separadamente, nota-se que todos os anticorpos foram capazes de responder/ligar às moléculas de oxLDL, monstrando que os três anticorpos encontravam-se viáveis após a contrução do imunossensor. Figura obtida de Cabral-Miranda et al. (2014). 


\subsection{Otimização do Imunossensor}

Com as respostas positivas do imunossensor para partículas de oxLDL, testes de seletividade, além dos resultados positivos com os anticorpos separadamente, houve o retorno dos trabalhos com os três anticorpos juntos para montar o biochiip.

O passo seguinte foi testar se nesse padrão de construção do imunossensor e ensaios com EIS a um potencial padrão de $0,12 \mathrm{~V}$ e potencial senoidal de resistência com uma amplitude de 0,01 V, número de frequências iguais a 50 e logaritmicamente distribuídos ao longo de um intervalo de 0,1-100 kHz, o imunossensor conseguiria mostrar uma resposta linear em variadas concentrações de oxLDL.

A resposta mostrou que o biossensor responde bem a uma concentração de 5 $\mu \mathrm{g} / \mathrm{mL}^{-1}$ de oxLDL diluído em PBS, sendo este o nível de concentração compreendida na gama de resposta linear do dispositivo. A resposta linear foi observada até $20 \mu \mathrm{g} / \mathrm{mL}^{-1}$, sendo expressa como Rct $(\Omega)=41.33$ x oxLDL $\left(\mu \mathrm{g} / \mathrm{mL}^{-1}\right)+1267.4$, com o coeficiente de correlação de 0,995. 0 desvio padrão das medições repetidas foi inferior a 5\%. (Tabela 1; Figuras 9 e 10) 
Figura 9 - Respostas eletroquímicas EIS obtidas com a montagem do imunossensor utilizando os três anticorpos juntos.

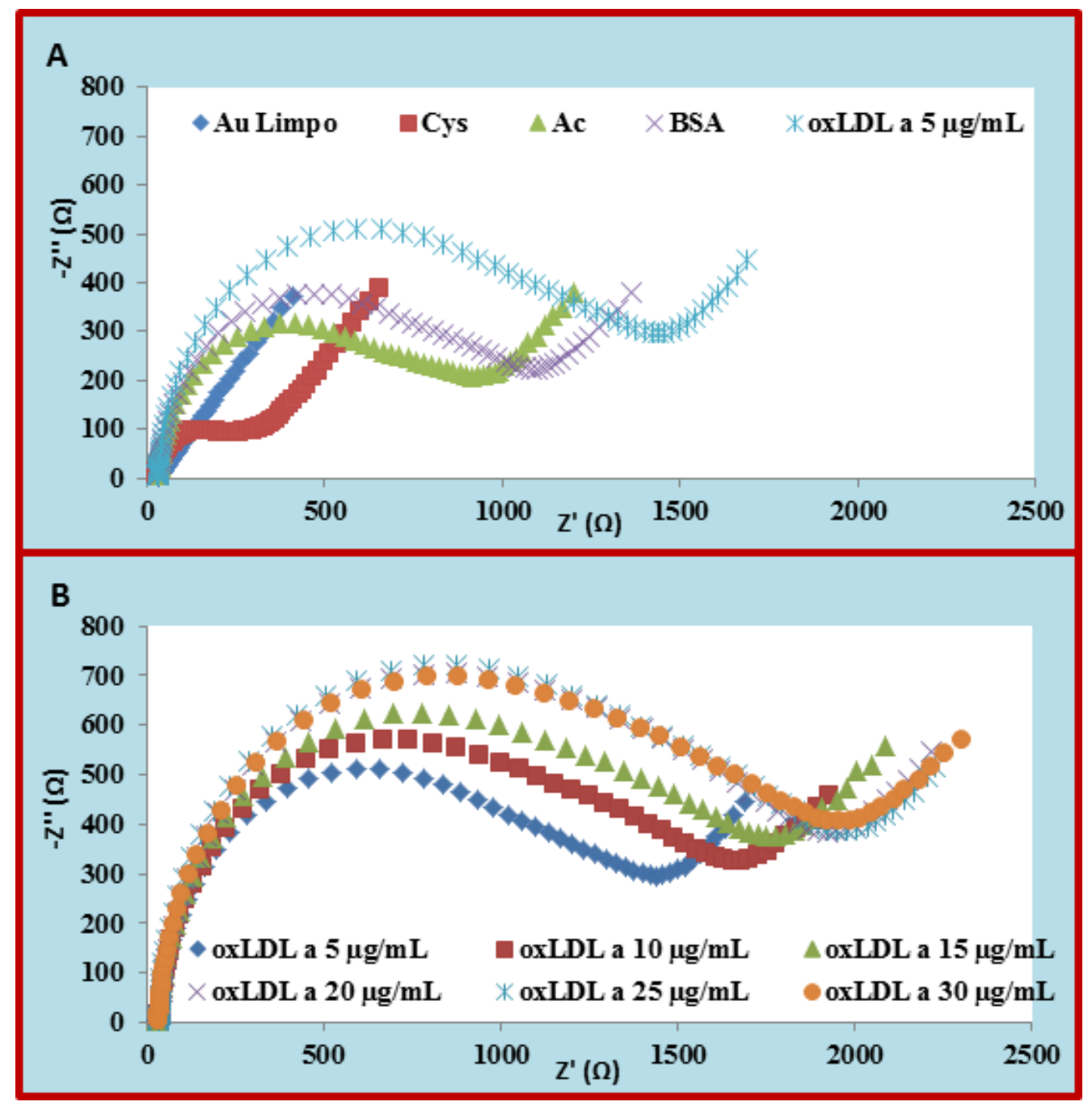

A primeira figura (A) mostra a leitura da superfície limpa do Au-SPR, Cys, Ac73, 77 e 87 juntos, bloqueou com BSA e a resposta para a primeiro aplicação da solução contendo oxLDL a $5 \mu \mathrm{g} / \mathrm{mL}^{-1}$. Em posterior é mostrado a calibração com variadas concentrações de oxLDL, especificamente de 5 a $30 \mu \mathrm{g} / \mathrm{mL}^{-1}$ (B). Figura obtida de Cabral-Miranda et al. (2014). 
Tabela 1 - Curva de Calibração da oxLDL nas concentrações de 5 a $30 \mu \mathrm{g} / \mathrm{mL}^{-1}$.

\begin{tabular}{clllc}
$\begin{array}{c}\text { Procedimento de } \\
\text { Imobilização }\end{array}$ & Soluções & Concentrações & Tempo & Ret $(\Omega)$ \\
& & & & \\
Funcionalização & Cisteamina & $50 \mathrm{mM}$ & $1 \mathrm{~h}$ & 267.99 \\
Anticorpos & 73,77 e 87 & $50 \mu \mathrm{g} / \mathrm{mL}^{-1}$ & $1 \mathrm{~h}$ & 916.02 \\
Solução Bloqueadora & BSA & $0.5 \mathrm{mg} / \mathrm{mL}^{-1}$ & $1 \mathrm{~h}$ & 1091.7 \\
& & & & \\
Calibração com oxLDL & & & & Ret \\
& & & & $\mathbf{( \Omega )}$ \\
& oxLDL & $5 \mu \mathrm{g} / \mathrm{mL}^{-1}$ & $15 \mathrm{~min}$ & 1456.4 \\
& & $10 \mu \mathrm{g} / \mathrm{mL}^{-1}$ & $15 \mathrm{~min}$ & 1701.5 \\
& & $15 \mu \mathrm{g} / \mathrm{mL}^{-1}$ & $15 \mathrm{~min}$ & 1898.4 \\
& & $20 \mu \mathrm{g} / \mathrm{mL}^{-1}$ & $15 \mathrm{~min}$ & 2079.6 \\
& & $25 \mu \mathrm{g} / \mathrm{mL}^{-1}$ & $15 \mathrm{~min}$ & 2076.2 \\
& & $30 \mu \mathrm{g} / \mathrm{mL}^{-1}$ & $15 \mathrm{~min}$ & 2086.2 \\
\hline
\end{tabular}

A tabela apresenta os dados numéricos referidos na figura 9, mostrando que a mudança na resistência ocorreu desde o acréscimo de Cisteamina ao oxLDL a $30 \mu \mathrm{g} / \mathrm{mL}^{-1}$.

Figura 10 - Gama linear da curva de calibração do imunossensor.

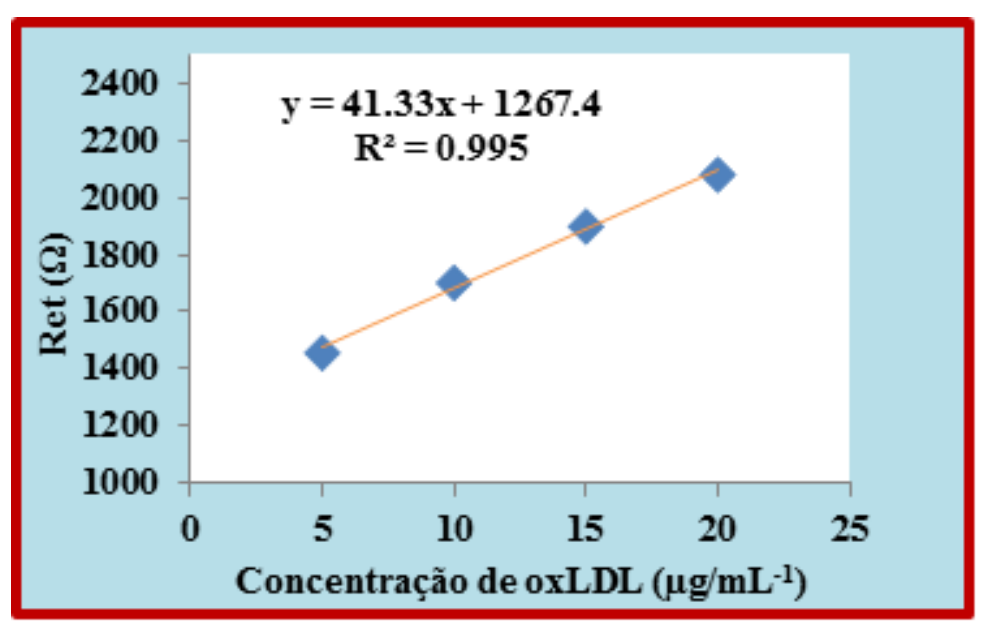

A melhor resposta da gama linear com a leitura eletroquímica EIS foi obtido calibrando com oxLDL nas concentrações de 5 a $20 \mu \mathrm{g} / \mathrm{mL}-1$, apesar do imunossensor ter respondido até $30 \mu \mathrm{g} / \mathrm{mL}^{-1}$, como mostra a figura 9 e a tabela 1 . 


\subsection{Testes do Imunossensor com oxLDL Diluido em Soro Fetal Bovino}

Considerando que o imunossensor foi desenvolvido para detectar oxLDL em amostras reais de sangue/plasma humano, seria importante verificar o desempenho deste sob condições próximas do real. Isto foi feito através da substituição do tampão PBS por FCS puro (composição biológica real) e/ou FCS diluído.

A leitura eletroquímica EIS do imunossensor com oxLDL diluída em FCS mostrou clara evidência da capacidade de detecção de oxLDL (Figura 11 B). Para garantir que o FCS não foi responsável por este aumento da resistência observada por EIS, um sinal em branco foi medido através da utilização de FCS sem oxLDL (Figura 11 A). Este controle negativo mostrou que todas as espécies biológicas presentes no FCS não foram capazes de impedir a detecção do oxLDL e nem de interagir com a superfície do imunossensor. 
Figura 11 - Resposta eletroquímica EIS do imunossensor com FCS sem oxLDL (A) ou FCS com oxLDL (B).

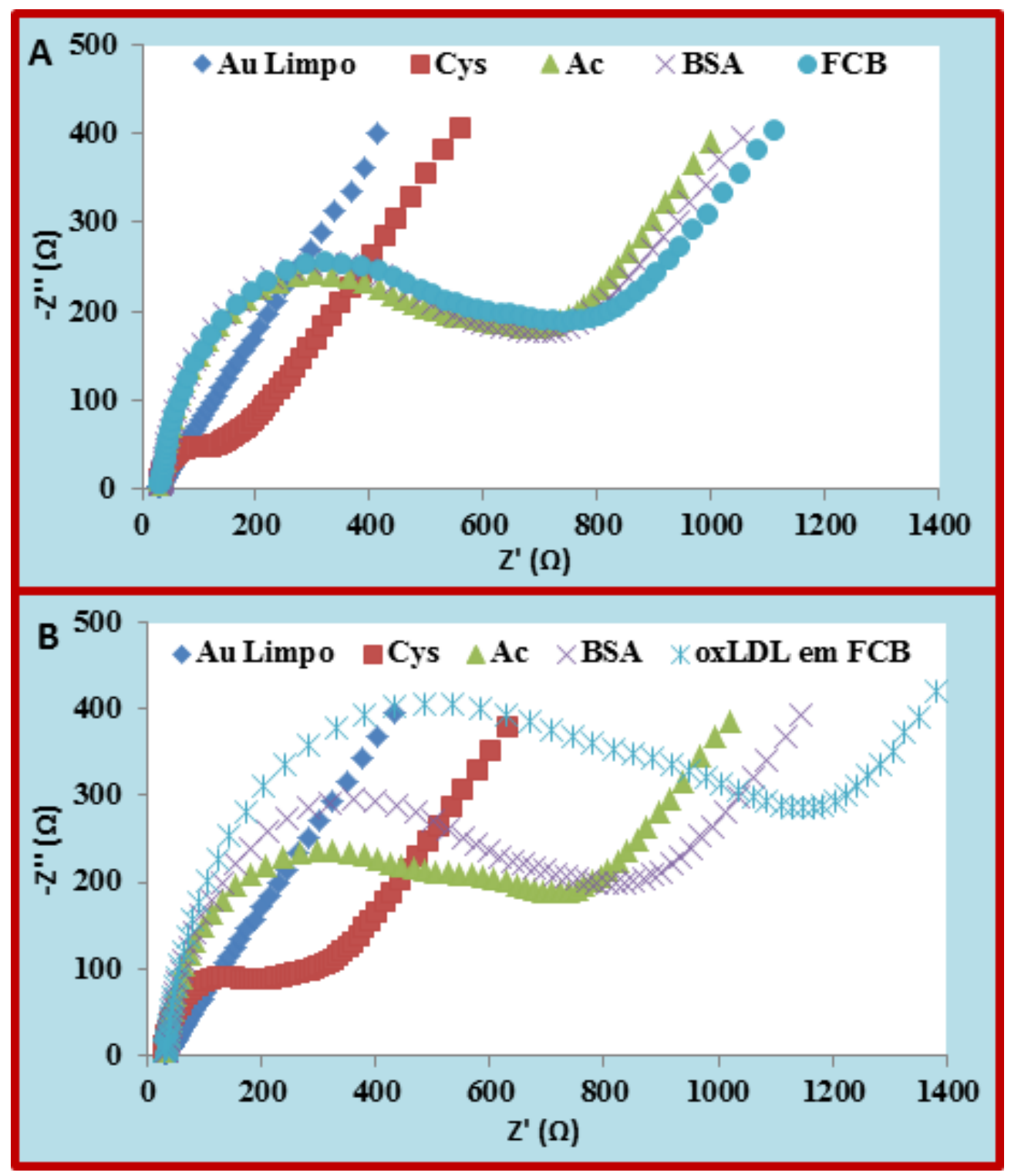

Obseravando as figuras A e B é perceptível a alteração das características elétricas com a adição de cisteamina (Cys) sobre o ouro limpo e posteriormente com a ligação dos anticorpos. Porém, em (A) a figura não mostra alteração quando foi adicionado BSA, pois não houve espaço livre para este se ligar. Diferentemente de (B), que após a adição de BSA, houve uma pequena alteração de resistência sobre o eletrodo. Nesse caso, mostra que a ligação dos anticorpos não foi suficiente para suprir todo o espaço do eletrodo de trabalho. Na fase seguinte, ao acrescentar FCS sem oxLDL (A), o imunossensor não demonstrou nenhuma alteração de impedância, diferentemente de quando foi acrescentado oxLDL diluído em FCS (B). Isso mostra que o Imunossensor consegue detectar oxLDL mesmo em solução biológica (soro). Figura obtida de Cabral-Miranda et al. (2014). 
O desempenho analítico do imunossensor também foi verificado através da calibração do dispositivo com padrões de oxLDL diluídos em FCS. A faixa de concentração da oxLDL utilizada nesta calibração foi de 0,50 - $50 \mu \mathrm{g} / \mathrm{mL}^{-1}$. Sob estas condições, o imunossensor foi capaz de detectar a oxLDL de 0,50 a 18,0 $\mu \mathrm{g} / \mathrm{mL}^{-1}$. Os valores de inclinação e intercepção foram, respectivamente, $62,43\left(\Omega \times \mathrm{mL}_{\mu} \mathrm{g}^{-1}\right)$ e 540.2 $\Omega$, com um coeficiente de correlação quadrado de 0,9951 (Tabela 2; Figura 12A e B). 0 limite de detecção foi de $0,22 \mu \mathrm{g} / \mathrm{mL}^{-1}$, calculado como a intercepção entre as partes lineares e não lineares da curva de calibração (Figura 13). 
Figura 12 - Curva de calibração do Imunossensor utilizando oxLDL diluída em FCS.

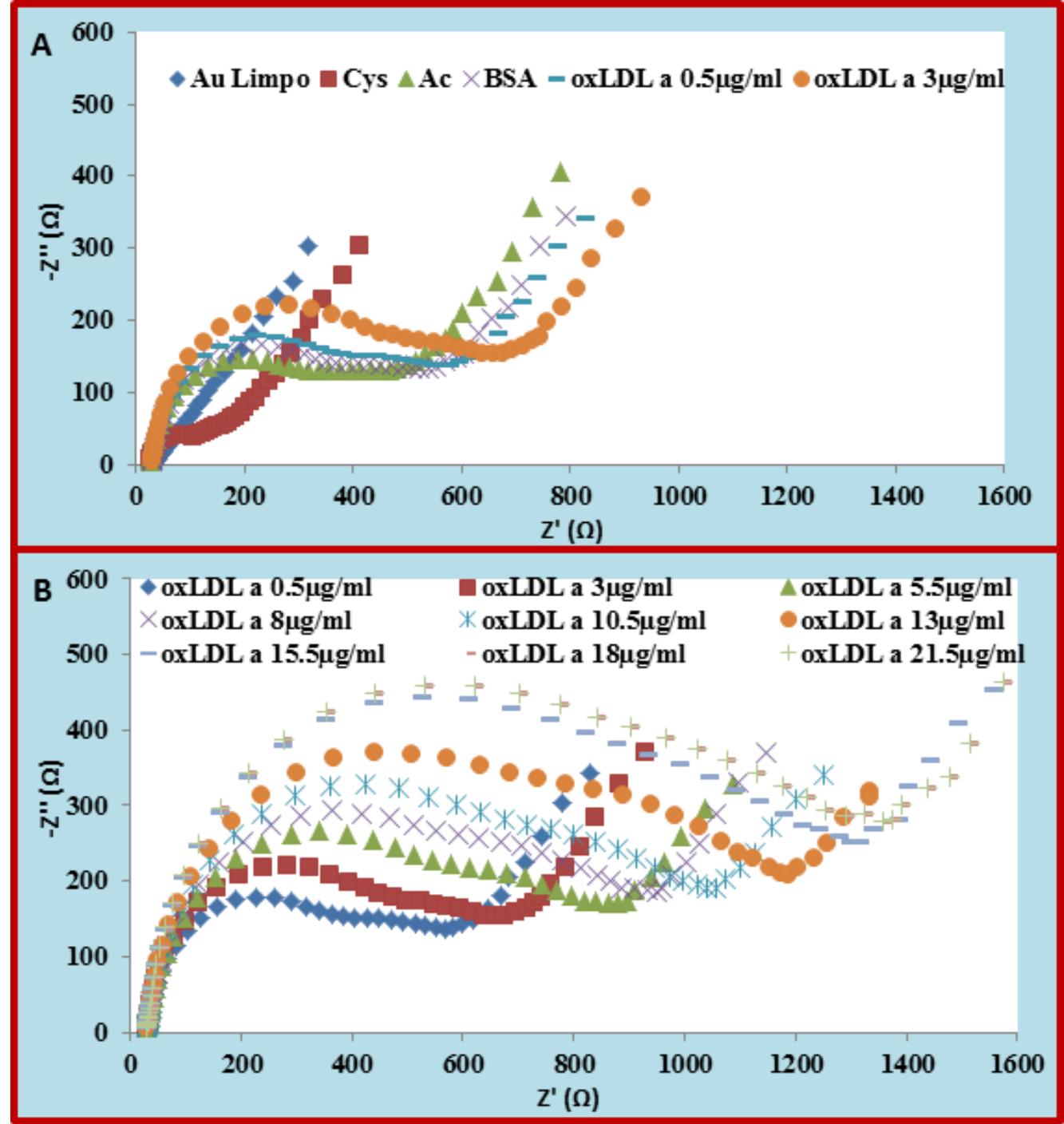

A figura mostra que após montar o Imunossensor, ou seja, adicionar Cys sobre o ouro limpo, ligar os anticorpos e bloquear com BSA, este foi testado a responder diferentes concentrações de oxLDL diluída em FCS. A figura (A) montra os resultados da montagem do imunossensor e as primeiras diluições de oxLDL nas concentrações de 0,5 e $3 \mu \mathrm{g} / \mathrm{mL}^{-1}$. Visto que o imunossensor respondeu lijeiramente a 0,5 $\mu \mathrm{g} / \mathrm{mL}^{-1}$, porém, a resposta com melhor visibilidade foi quando a concentração de oxLDL era de $3 \mu \mathrm{g} / \mathrm{mL}$ 1. Em (B) há a calibração completa, de 0,5 a $21,5 \mu \mathrm{g} / \mathrm{mL}^{-1}$, momento de estabilidade elétrica e não mais altera a impedância sobre o eletrodo de trabalho. Figura obtida de Cabral-Miranda et al. (2014). 
Tabela 2 - Curva de Calibração da oxLDL diluido em FCS nas concentrações de 0,5 a $21,5 \mu \mathrm{g} / \mathrm{mL}^{-1}$.

\begin{tabular}{|c|c|c|c|c|}
\hline $\begin{array}{l}\text { Procedimento de } \\
\text { Imobilização }\end{array}$ & Soluções & $\begin{array}{c}\text { Concentraçõe } \\
\text { s }\end{array}$ & Tempo & $\operatorname{Ret}(\Omega)$ \\
\hline Funcionalização & Cisteamina & $50 \mathrm{mM}$ & $1 \mathrm{~h}$ & 109,98 \\
\hline Anticorpos & 73,77 e 87 & $50 \mu \mathrm{g} / \mathrm{mL}^{-1}$ & $1 \mathrm{~h}$ & 440,28 \\
\hline Solução Bloqueadora & BSA & $0.5 \mathrm{mg} / \mathrm{mL}^{-1}$ & $1 \mathrm{~h}$ & 480,33 \\
\hline \multirow[t]{10}{*}{ Calibração com oxLDL } & & & & $\operatorname{Ret}(\Omega)$ \\
\hline & oxLDL & $0,5 \mu \mathrm{g} / \mathrm{mL}^{-1}$ & $15 \mathrm{~min}$ & 541,30 \\
\hline & & $3 \mu \mathrm{g} / \mathrm{mL}^{-1}$ & $15 \mathrm{~min}$ & 734,79 \\
\hline & & $5,5 \mu \mathrm{g} / \mathrm{mL}^{-1}$ & $15 \mathrm{~min}$ & 902,54 \\
\hline & & $8 \mu \mathrm{g} / \mathrm{mL}^{-1}$ & $15 \mathrm{~min}$ & 1056,1 \\
\hline & & $10,5 \mu \mathrm{g} / \mathrm{mL}^{-1}$ & $15 \min$ & 1192,7 \\
\hline & & $13 \mu \mathrm{g} / \mathrm{mL}^{-1}$ & $15 \mathrm{~min}$ & 1376,5 \\
\hline & & $15,5 \mu \mathrm{g} / \mathrm{mL}^{-1}$ & $15 \min$ & 1473,6 \\
\hline & & $18 \mu \mathrm{g} / \mathrm{mL}^{-1}$ & $15 \min$ & 1497,36 \\
\hline & & $21,5 \mu \mathrm{g} / \mathrm{mL}^{-1}$ & $15 \min$ & 1491,4 \\
\hline
\end{tabular}

A tabela apresenta os dados numéricos referidos na figura 12, visto que na curva de calibração houve aumento de resistência até $18 \mu \mathrm{g} / \mathrm{mL}^{-1}$ de oxLDL diluida em FCS. 
Figura 13 - Gama linear da curva de calibração do imunossensor com oxLDL variando de 0,5 a $15,5 \mu \mathrm{g} / \mathrm{mL}^{-1}$.

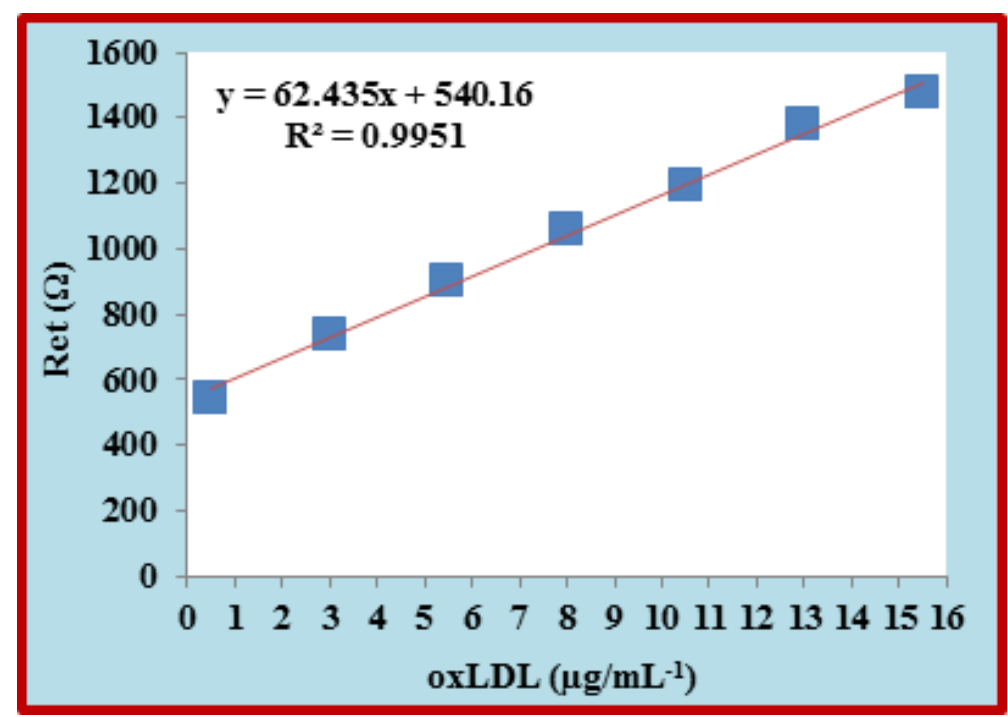

A figura mostra que a melhor resposta da gama linear na calibração de oxLDL diluído em FCS foi nas concentrações de 0,5 a 15,5 $\mu \mathrm{g} / \mathrm{mL}^{-1}$, mesmo que o imunossensor tenha mostrado resposta até 18 $\mu \mathrm{g} / \mathrm{mL}^{-1}$, como mostra a figura 13 e a tabela 2 .

Ensaios com SWV também foram realizados durante a calibração do imunossensor diluindo a oxLDL em FCS. Essas leituras foram realizadas em paralelo com a leitura eletroquímica EIS, como forma de comparação dos métodos. Os voltamogramas obtidos dos ensaios com SWV podem ser vistos na figura 14. No geral, a montagem do dispositivo mostrou diminuição da corrente de pico da sonda redox (Figura 14 A), o qual estava consistente com os dados obtidos por EIS. Porém, a calibração em SWV apresentou respostas lineares variando somente entre 3,0 e 10, $\mu \mathrm{g} / \mathrm{mL}^{-1}$ (Figura 14 B), apontando para EIS como a técnica mais adequada para aplicação analítica. 
Figura 14 - Resposta da montagem por SWV do imunossensor e a curva de calibração diluíndo oxLDL em FCS

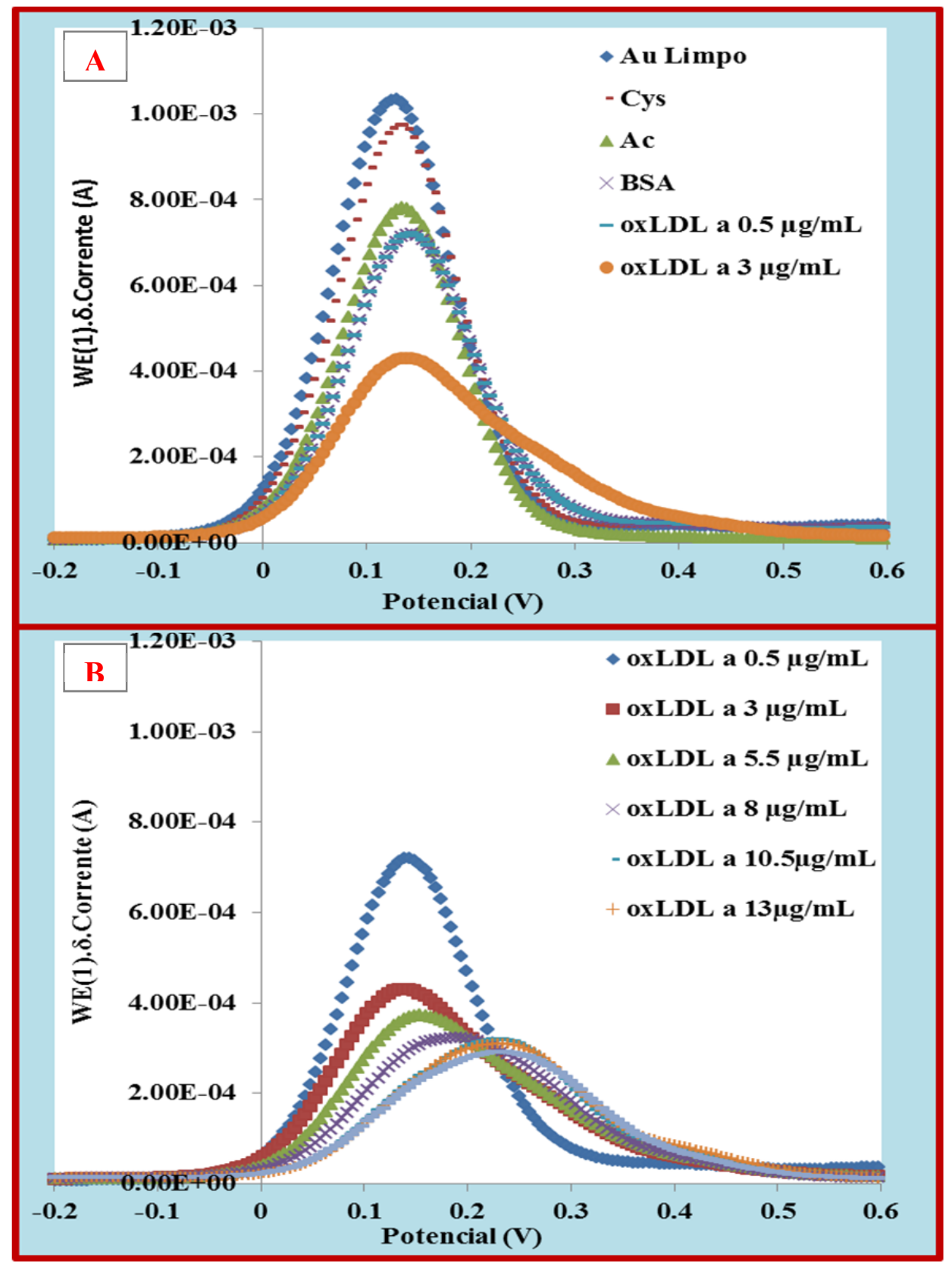

A figura mostra os voltamogramas obtidos nos ensaios com SWV, onde em (A) é visto os resultados da montagem do imunossensor e as primeiras diluições de oxLDL nas concentrações de 0,5 e $3 \mu \mathrm{g} / \mathrm{mL}^{-1}$. Corroborando com os resultados obtidos por EIS, o imunossensor mostrou diminuição da corrente de pico da sonda. Em (B) é mostrado a calibração por completo, de 0,5 a $13 \mu \mathrm{g} / \mathrm{mL}^{-1}$, momento de estabilidade elétrica que não há mais alterção da impedância sobre o eletrodo de trabalho, ou seja, a calibração em SWV apresentou respostas lineares variando somente entre 3,0 e 10, $\mu \mathrm{g} / \mathrm{mL}^{-1}$, apontando para EIS como a técnica mais adequada para aplicação analítica. Figura obtida de Cabral-Miranda et al. (2014). 


\subsection{Síntese dos Anticorpos Plásticos}

A síntese dos anticorpos plásticos foi dividida em duas partes, utilizando dois $\mathrm{Au}$ SPEs onde apenas os eletrodos de trabalho dos Au-SPEs foram modificados. 0 eletrodo de trabalho do Au-SPE-1 foi modificado por uma camada de PVC-carboxilado, onde este polímero foi então deixado para secar durante um dia, para posterior incubação com NHS durante 10 minutos e, em seguida, com as soluções EDAC + NHS durante 2 horas, como forma de ativação das regiões carboxílicas do polímero PVC. Em posterior foi adicionada oxLDL e mantida por 4 horas, a qual serviu como molde para polimerização dos anticorpos plásticos. Todos os passos para construção do MAPS foram acompanhados por leitura eletroquímica EIS, como forma de garantia que o processo estava seguindo como previsto, ou seja, o polímero ou anticorpo plástico anti oxLDL estava sendo contruído. 0 resultado eletroquímico mostrou que todos esses passos anteriormente citados foram capazes de ser mensurados, pois demonstraram resultados visíveis como visto na Figura 15.

As partículas de oxLDL adicionadas à superfície do Au-SPE-1, ligaram-se facilmente com os grupos carboxílicos anteriormente ativados, formando assim uma ligação amida. Etilenodiamina foi adicionada em posterior para desativar os grupos carboxílicos que permaneceram ativos após a ligação das partículas de oxLDL, seguindo com a adicão de cargas sobre as partículas de oxLDL. Para esta finalidade foi utilizado vinil benzoato (polar) mais cloreto de vinil benzil trimetil amônio (carregada positivamente). Isto foi obtido através de um arranjo monomérico pré-estabelecido por meio de interações electrostáticas/iônicas entre os locais carregados acessíveis situados sobre a superfície do molde e os monômeros de vinil exteriores que transportam grupos carregados.

Após isto, a superfície contendo as moléculas de oxLDL foi polimerizada, ocorrendo a formação de uma matriz rígida, reticulada e com excelente capacidade de mensuração eletroquímica. Os grupos funcionais carboxílicos na superfície exterior do polímero foram ativados antes da ligação com o Au-SPE-2, o qual foi preparado em paralelo, para retirar o polímero formado sobre as moléculas de oxLDL.

Sobre o Au-SPE-2 foi adicionado ácido mercaptopropiônico como a primeira camada no eletrodo de trabalho, o qual é composto por uma cadeia de três átomos de carbono com um grupo carboxílico em uma extremidade e uma função tiol (-SH) na 
outra extremidade. $\mathrm{O}$ contato entre a camada de ouro $\mathrm{(Au})$ do eletrodo de trabalho e oSH levam à formação espontânea de uma interação forte Au-enxofre e a formação de uma camada carboxílica estável na superfície exterior do ouro. Esta superfície, depois de ativada por EDAC/NHS, recebeu etilenodiamina, a qual gerou uma camada de amina na superfície exterior do eletrodo de trabalho do Au-SPE-2, que serviu como agente de ligação entre os Au-SPE 1 e 2.

Os Au-SPE-1 e Au-SPE-2 foram, então, perfeitamente unidos com as regiões dos eletrodos de trabalho em frente um do outro, para que o Au-SPE-2 aderisse ao polímero formado no Au-SPE-1 de forma a extraí-lo. No dia seguinte, os Au-SPE-1 e Au-SPE-2 colados um no outro, foram imersos em água com posterior separação dos Au-SPEs, onde o Au-SPE-2 retirou a camada polimérica e parte das partículas de oxLDL covalentemente ligado a ele, as quais foram removidas por incubação com proteinase $\mathrm{K}$, obtendo assim, a superfície sensorial dos MAPSs (Figuras 5 e 15).

\subsection{Acompanhamento das Modificações Químicas no Au-SPE}

As sucessivas modificações químicas na área de trabalho do eletrodo mudaram suas características elétricas, onde a montagem do polímero anti-oxLDL foi seguida através do monitoramento da capacidade de transferência de elétrons do Au-SPE para o par redox (ferri/ferro) (Figura15). No presente, o componente imaginário de impedância (Z", fora-de-fase) foi plotado contra o componente de impedância real (Z ', em fase) para cada frequência. Como esperado, esses gráficos mostram uma região de semicírculo sobre o eixo real na faixa de alta freqüência, o que indica um processo de transferência de carga controlada, na qual o seu diâmetro igualou a cinética de transferência de elétrons da sonda redox na interface do eletrodo. Esta região foi seguida por um comportamento linear na gama de frequência mais baixa, o que implica um processo de transferência de massa limitada.

O ouro limpo dos Au-SPE-1 e Au-SPE-2 mostrou um pequeno domínio semicírculo, sugerindo um processo de transferência de elétrons muito rápido com um passo limitante difusional. Porém, com a adição de PVC-COOH, oxLDL e polímero no AuSPE-1, deu-se origem a aumentos consecutivos na resistência de transferência de elétrons, resultando em aumentos na seção semicircular. 
A ligação do mercaptopropiônico no Au do SPE-2 também contribuiu para um aumento moderado da resistência, como esperado para compostos tiol, de pequena cadeia de carbono, ligados ao ouro. Comparado a isto, a posterior ligação na camada do polímero formado no Au-SPE-1 promoveu um grande aumento da resistência. Parte das moléculas de oxLDL estava, entretanto, presente dentro deste filme polimérico do $\mathrm{Au}$ SPE-2, pois a ação subseqüente da protease diminuiu o valor da resistência. 
Figura 15 - Ensaios eletroquímicos EIS durante a construção dos anticorpos plásticos.

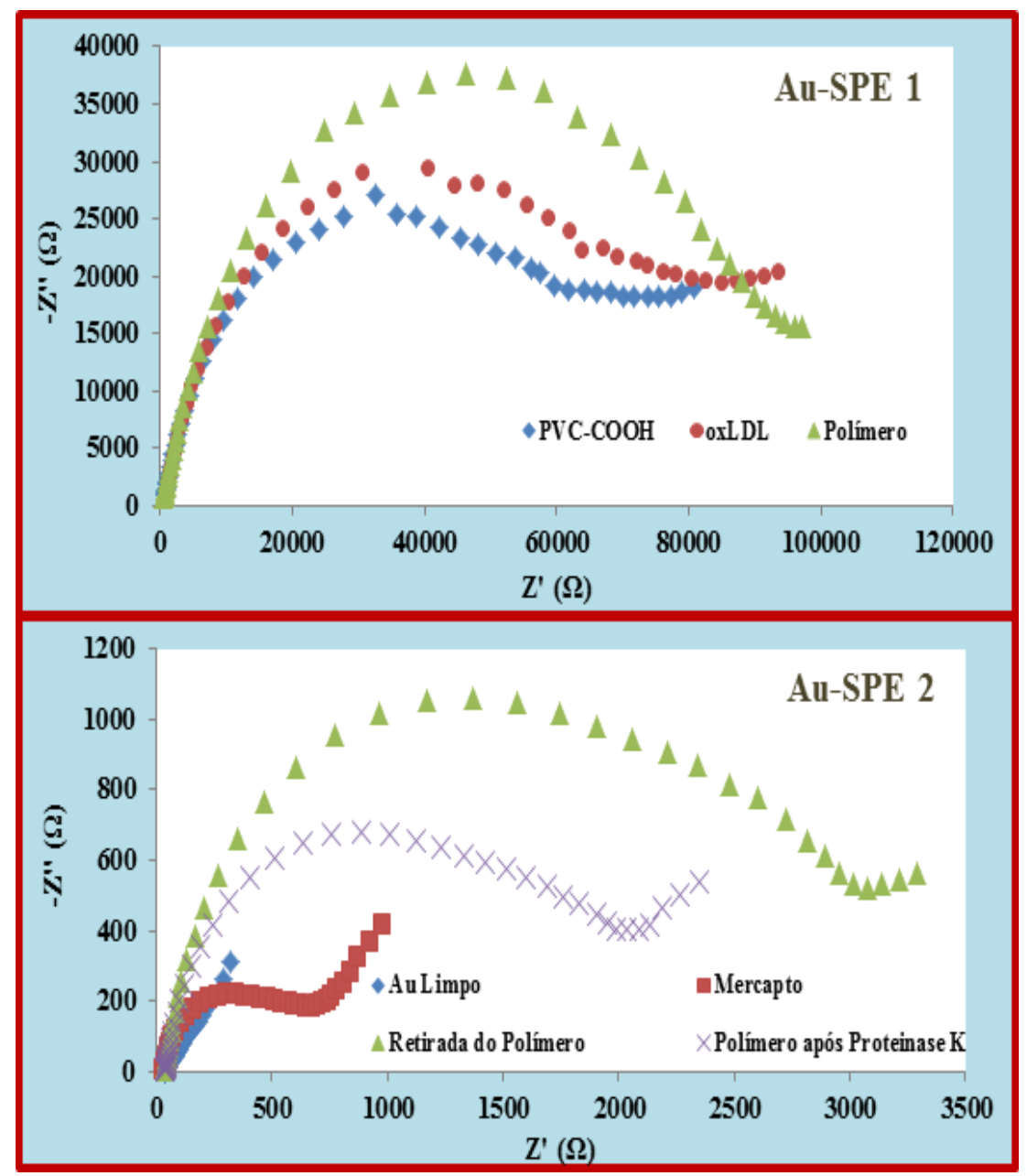

As modificações químicas durante o processo de contrução do MAPS foram acompanhadas por leituras eletroquímicas EIS, como mostra a figura acima. Observa-se na figura referente ao trabalho com o Au-SPE 1, que após adição de PVC carboxilado (PVC-COOH) houve grande aumento na resistência sobre o eletrodo de trabalho. Em seguida, com adição das moléculas de oxLDL, aumenta o grau de impedância, mostrando que estas adiriram à camada de PVC-COOH, para assim, ocorrer o processo de polimerização. É visto com crescimento da curva de resistência sobre o eletrodo na figura que foi montado um polímero sobre as moléculas de oxLDL. Paralelamente há a preparação do Au-SPE-2 para retirar o polímero preparado sobre o Au-SPE-1, com a adição de ácido mercaptopropiônico sobre ouro (Au) limpo. Observa que com a adição de Mercapto, aumenta a resistrência sobre o eletrodo de trabalho do Au-SPE-2, que após adicionar agente de ligação EA (não há leitura EIS), os eletrodos são alinhados e unidos um ao outro. Em seguida houve a separação dos Au-SPE 1 e 2 e feito mais leituras EIS com Au-SPE 2, para saber se houve a retirada do polímero, o qual mostra considerado aumento da resistência. Posteriormente, é adicionado Proteinase K sobre o polímero para digestão de possíveis remanescente de partículas de oxLDL, o qual mostra diminuição da resistência, ou seja, ao retirar o polímero preparado no Au-SPE 1, o Au-SPE-2 retirou também, fragmentos de oxLDL. Figura obtida de Cabral-Miranda; Gidlund; Sales, (2014). 


\subsection{Análise dos Anticopos Plásticos por Microscopia Eletrônica de Varredura}

Os MAPS e NIM foram observados por microscopia eletrônica de varredura (SEM) e foram apresentados como materiais completamente diferentes, como vistos na figura 16.

Figura 16 - Imagem por SEM da superfície não-impressa (esquerda, NIM) e o material impresso, anticorpos plásticos (direito, MAPS).

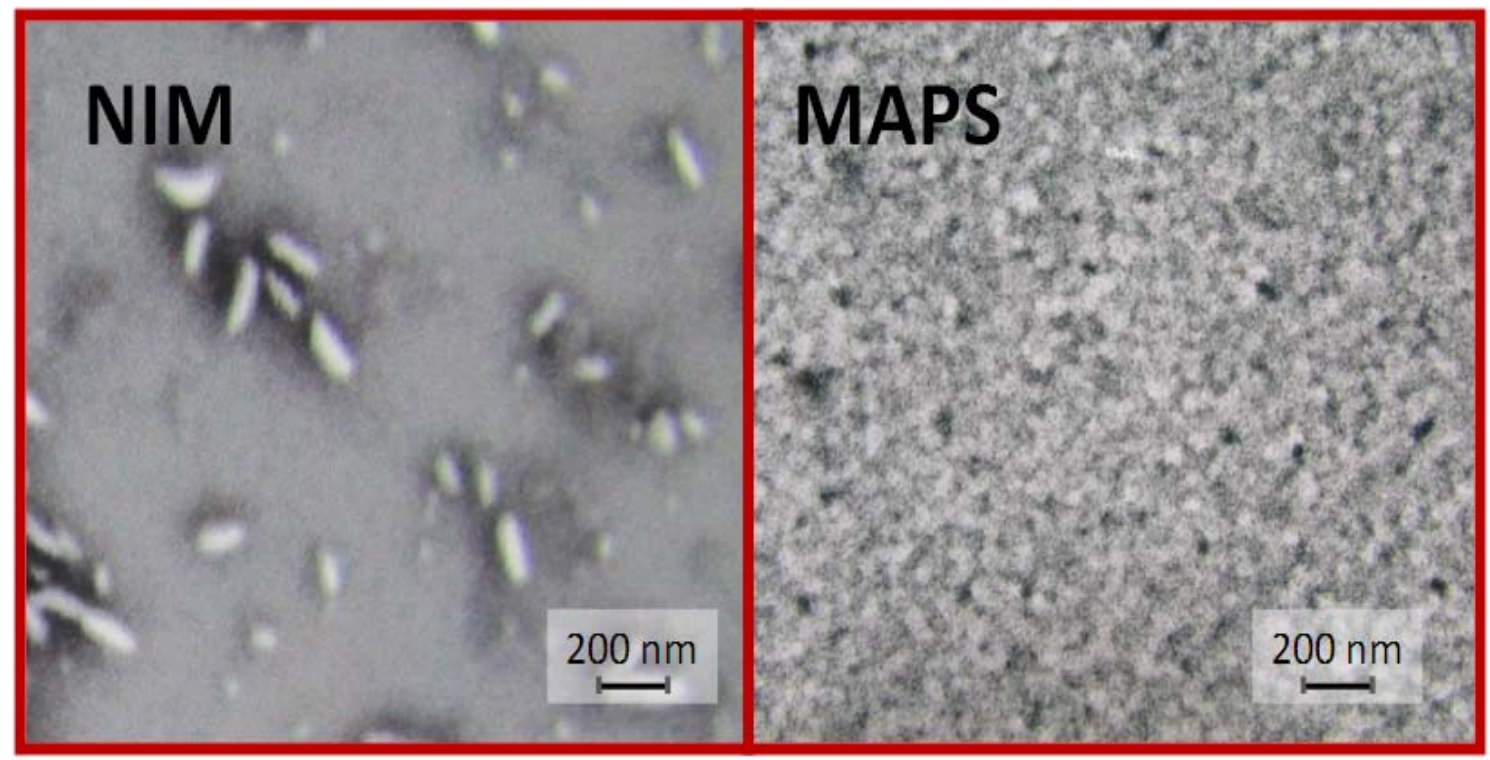

Figura obtida de Cabral-Miranda; Gidlund; Sales, (2014)

A superfície do MAPS mostrou uma alta densidade de "poros" com diferentes tamanhos (Figura 16, à direita), os quais são referentes aos sítios de ligação das moléculas de oxLDL, que foram usadas como moléculas molde para construção desta rede polimérica. Corroborando com a ampla variação de tamanho das moléculas de oxLDL previamente mensuradas por DLS, os poros da superfície do MAPS variou de acordo com a gama de tamanho das moléculas de oxLDL.

Na superfície do material NIM, encontraram-se pequenos aglomerados de polímero (Figura 16, esquerda). Esta observação foi inesperada, mas pode está correspondendo à presença de resíduos de PVC-COOH, remanescente após a separação do Au-SPE-1 e AuSPE-2. 


\subsection{Análise dos Anticopos Plásticos por Raman}

A espectroscopia de Raman com microscopia confocal é uma técnica que permite obter informação química sobre um determinado material sólido. Nesta técnica, um feixe laser incide sobre a amostra e devolve o espectro relativo ao ponto da amostra xyz que sofreu impacto do laser. Embora a interpretação da microscopia de Raman seja de algum modo análoga à de Infravermelho, ela permite obter sinais muito sensíveis decorrentes da presença de carbono nas amostras.

Relativamente aos espectros obtidos (Figura 17), é possível verificar as enormes semelhanças de registo entre os materiais MAPS e NIM. Esta semelhança revela semelhanças estruturais, do ponto de vista químico, entre os dois, o que significa que a polimerização decorreu com sucesso em ambos os biossensores e que a oxLDL foi removida de modo eficaz desde a superfície sensora.

Figura 17 - Análise dos MAPS e NIM por Raman.

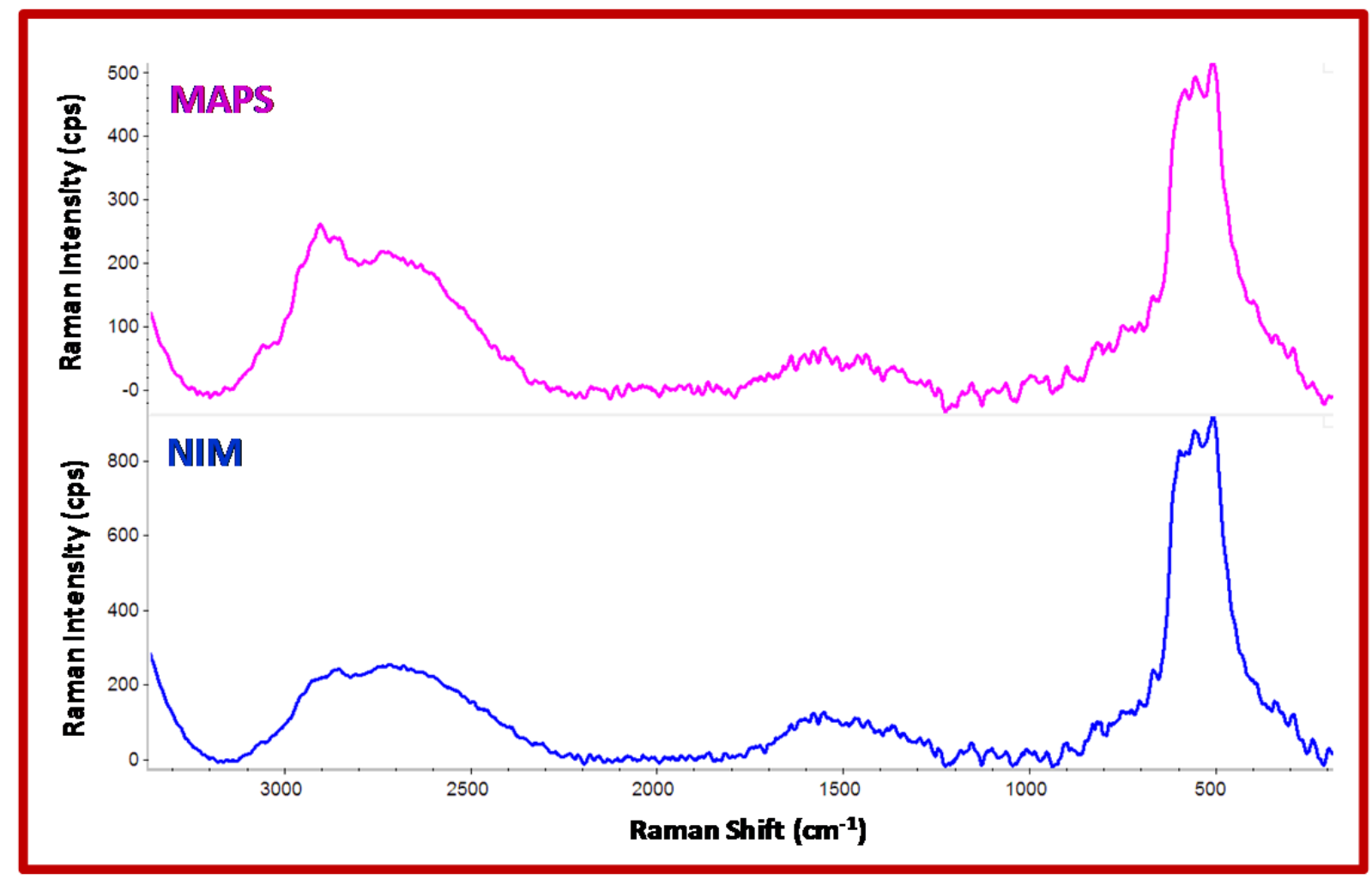

Figura obtida de Cabral-Miranda; Gidlund; Sales, (2014). 


\subsection{Ensaios Experimentais com MAPS e NIM para detecção de oxLDL}

Os MAPS foram construidos, mas até então, não haviam sido testados se era capazes detectar moléculas de oxLDL, pois esse foi o objetivo de desenvolver esses anticorpos plásticos. Por isso, o passo seguinte foi testar se as superfícies dos MAPS teriam a capacidade de interagir com as moléculas molde; e estes testes foram acompanhados por EIS.

Com esta finalidade, $10 \mu \mathrm{L}$ de uma solução contendo oxLDL a $50 \mu \mathrm{g} / \mathrm{mL}^{-1}$ preparada em tampão PBS foi adicionada sobre a superfície dos MAPS e dos NIM e deixado reagindo por um período de até 30 minutos. Acompanhando a reação por leitura eletroquímica EIS, o valor da resistência na superfície dos MAPS aumentou com a presença de oxLDL. Observou-se o aumento máximo da resistência até 15 minutos de incubação e o valor resultante da resistência manteve-se relativamente constante durante períodos de incubações mais longos. Devido a isso, todos os ensaios posteriores com o MAPS foram conduzidos por um período de 15 minutos de incubação.

Em relação à incubação com oxLDL sobre a superfície do NIM, esta não alterou o sinal elétrico, como visto na figura 18 abaixo. 
Figure 18 - Respostas eletroquímicas EIS dos MAPS (A) e NIM (B) a altas concentrações de oxLDL diluida em PBS.

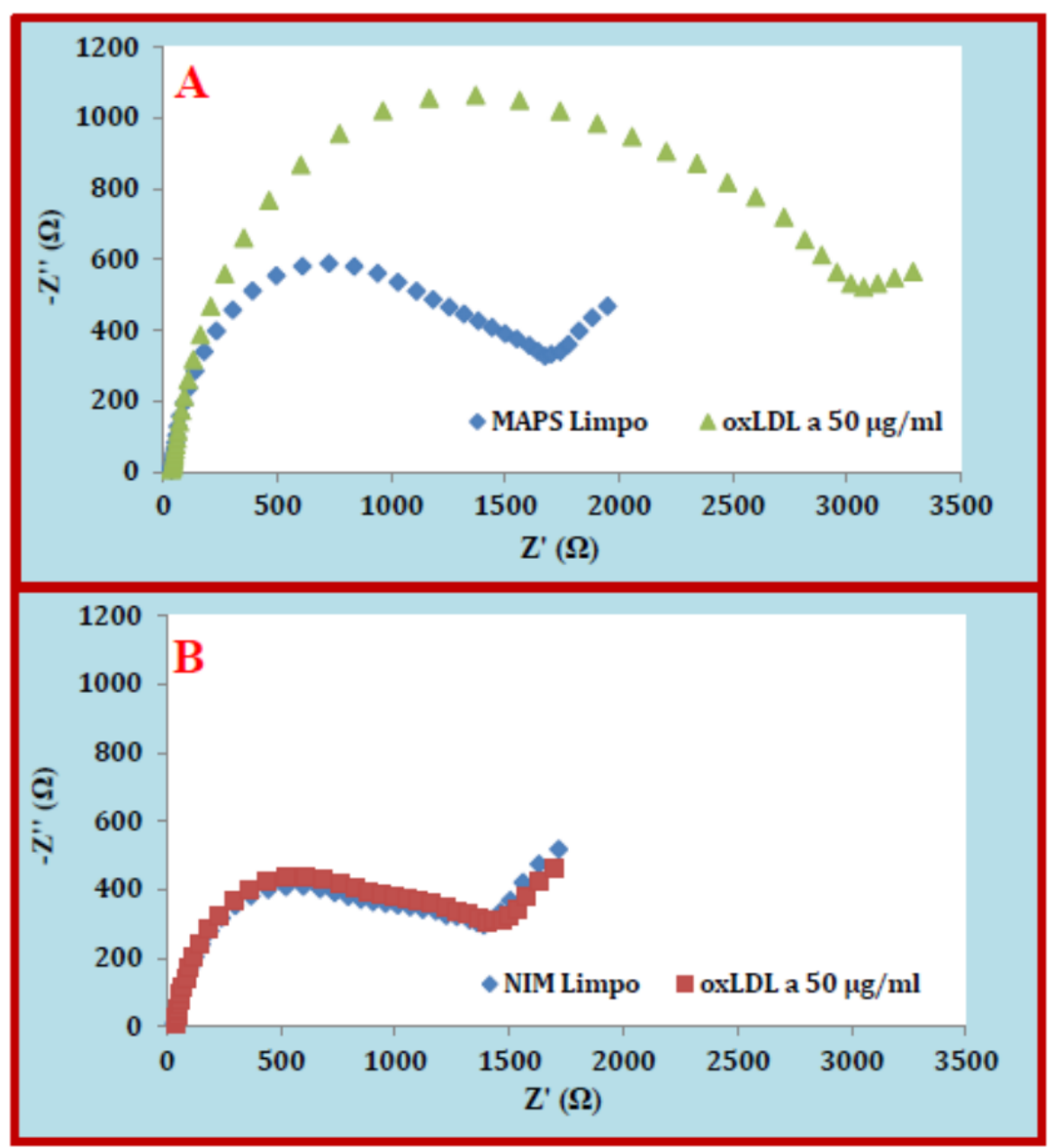

A figura mostra em (A) a leitura eletroquímica com o MAPS limpo e com oxLDL a $50 \mu \mathrm{g} / \mathrm{mL}^{-1}$ diluído em PBS; visto que, após adição de oxLDL houve enorme aumento da resistência eletroquímica. Porém em que (B), não houve diferença entre o NIM limpo e com oxLDL, também a $50 \mu \mathrm{g} / \mathrm{mL}^{-1}$. Figura obtida de CabralMiranda; Gidlund; Sales, (2014).

\subsection{Testes dos MAPSs com Controles Negativo}

A capacidade dos MAPSs para discriminar partículas coexistentes no sangue com oxLDL, foi verificada através de ensaios eletroquímicos EIS durante a incubação com LDL não oxidada, mioglobina e hemoglobina. A incubação foi feita colocando uma alíquota com $10 \mu \mathrm{L}$ das soluções contendo os antígenos supracitados a $50 \mu \mathrm{g} / \mathrm{mL}^{-1}$, diluídos em PBS, sobre a superfície dos MAPSs e deixado incubando por $1 \mathrm{~h}$ em temperatura ambiente. 
Figura 19 - Testes de especificidade do MAPS contra proteínas do soro que coexistem com oxLDL, (A) mioglobina, (B) hemoglobina e (C) LDL não oxidada.

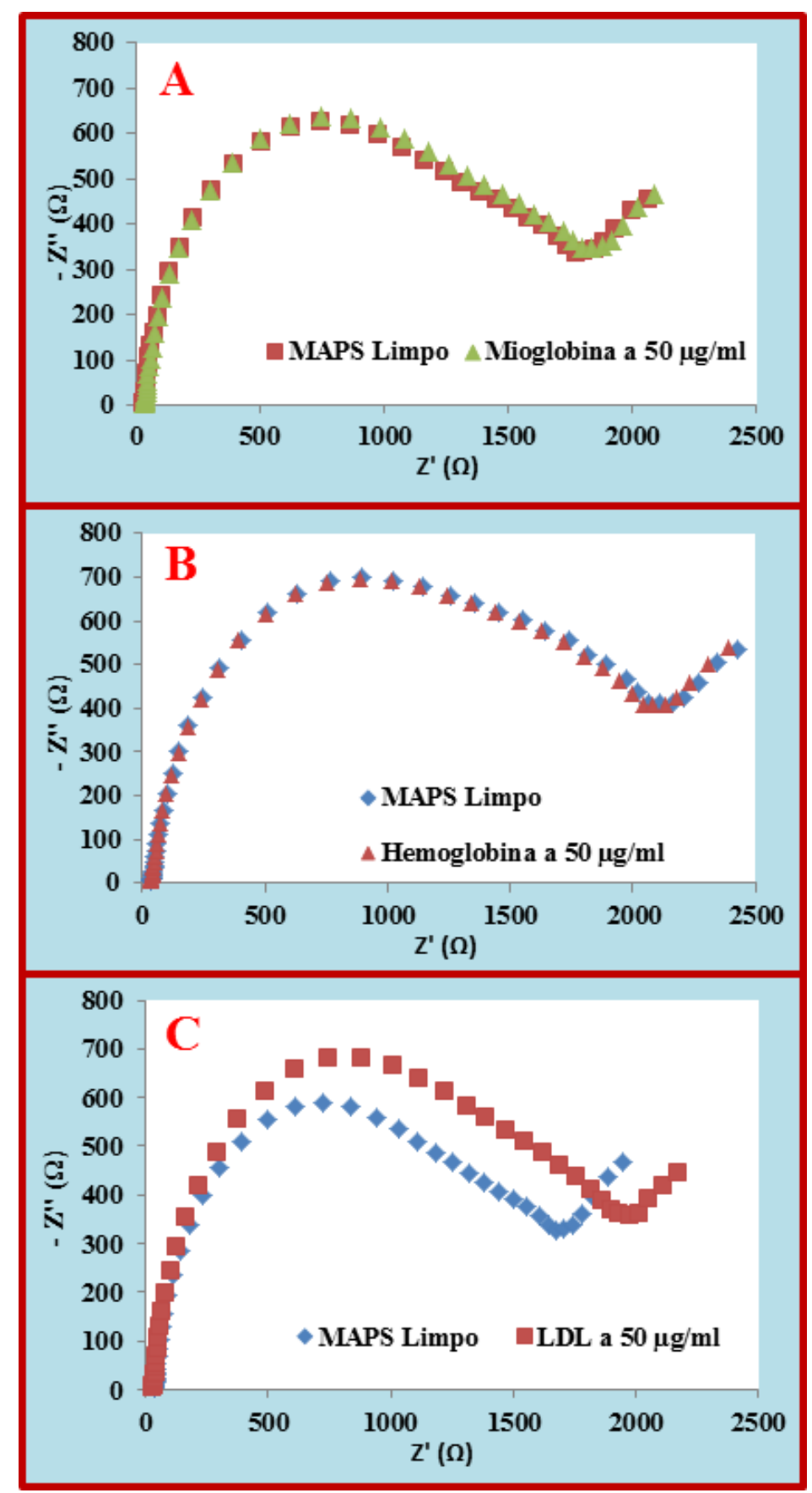

Pare saber se os anticorpos plásticos poderiam respoder a outros componentes biológicos, os MAPSs foram testados com mioglobina (A), hemoglobina (B) e LDL não oxidada (C). Para isso, foi feito leituras eletroquímicas EIS com os MAPSs limpos e após adição das moléculas supracitadas. Como mostra a figura, não houve diferença nas resistências sobre o eletrodo de trabalho, visível nas regiões estáveis dos semicírculo, entre o MAPS limpo e com mioglobina (A) ou hemoglobina (B). Porém, ao adicionar LDL não oxidada, a resistência entre o MAPS limpo e com LDL (C), alterou suas características elétricas, como mostram as regiões de semicírculos. Figura obtida de Cabral-Miranda; Gidlund; Sales, (2014). 
Como visto na Figura 19, tanto a mioglobina, quanto a hemoglobina foram incapazes de alterar o perfil eletroquímico do MAPS (Figura 19 A/B), demonstrando a excelente capacidade seletiva que os anticorpos plásticos têm. Porém, a presença de LDL não oxidada deu origem a um pequeno aumento da resistência, como visto na Figura 19 C. Mas a detecção das partículas de LDL não oxidada é bastante irrelevante, comparada com a resistência demonstrada com partículas de oxLDL, como visto na figura 20 abaixo.

\section{Figura 20 - Comparação das respostas eletroquímicas EIS do MAPS utilizando oxLDL e LDL não oxidada.}

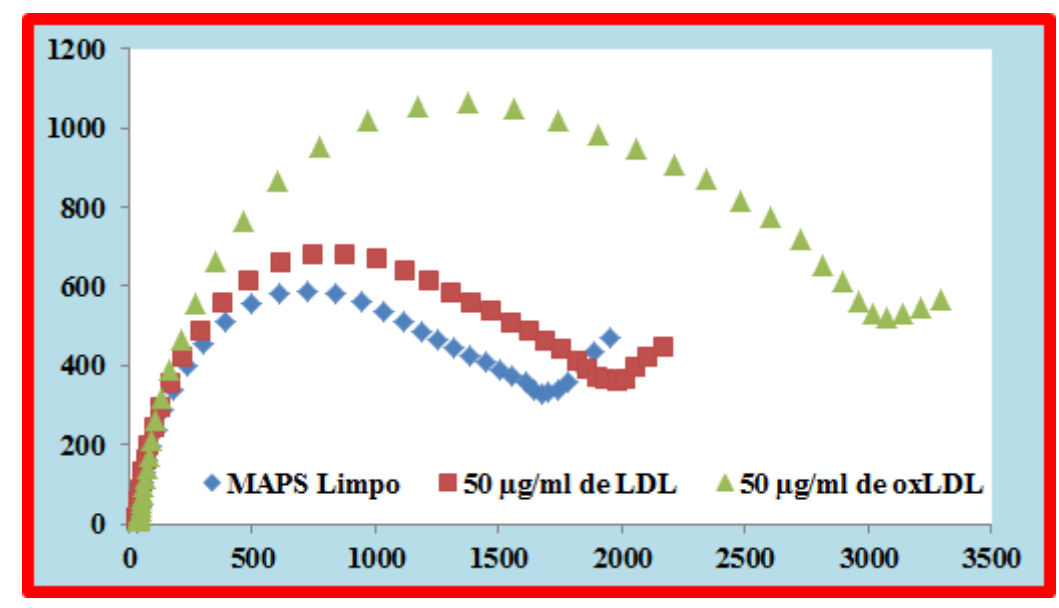

Após o MAPS demonstrar resposta positiva a LDL não oxidada, este mesmo MAPS foi submetido a detectar oxLDL para comparar o padrão de resposta. Como mostra a figura, entre o MAPS limpo e LDL há pequena diferença na resistência, porém, ao ser submetido a oxLDL, o padrão de resposta eletroquímica é visivelmente superior.

\subsection{Testes dos MAPSs com oxLDL diluído em soro fetal bovino}

Considerando-se que os anticorpos plásticos devem funcionar bem para detectar oxLDL circulante, para poder ser útil no contexto clínico, tornou-se importante verificar o desempenho dos MAPSs em condições próximas do real, como forma de aproximação aos testes realizados na rotina laboratorial, no qual as partículas de oxLDL são detectadas em sangue humano. Por isso, os anticorpos plásticos foram testados para detectar oxLDL diluído em FCS, mimetizando assim, um diagnóstico real, e não apenas diluído em tampão, o qual não contem competidores naturais capazes de dificultar o processo de ligação antígeno-anticorpo. 
Os resultados dos testes com oxLDL em FCS demonstraram aumento significativo da resistência na superfície dos MAPSs, expondo a capacidade dos anticorpos plásticos em detectar a presença de oxLDL, mesmo que este esteja em soro (Tabela 3, Figura 21). Para assegurar que este aumento da resistência na superfície dos MAPSs não veio da presença de outras partículas contidas no FCS, foi feito ensaios adicionais utilizando apenas o soro fetal bovino sem a presença de oxLDL humana. Como pode ser visto na figura 21A, ocorreu apenas ligeiras diferenças na resistência da superfície do MAPS após incubação com FCS sem oxLDL. Esse resultado mostra a grande seletividade que os anticorpos plásticos têm, como relatado em pontos anteriores.

\section{Figura 21 - Curva de Calibração do MASP com oxLDL diluida em FCS.}

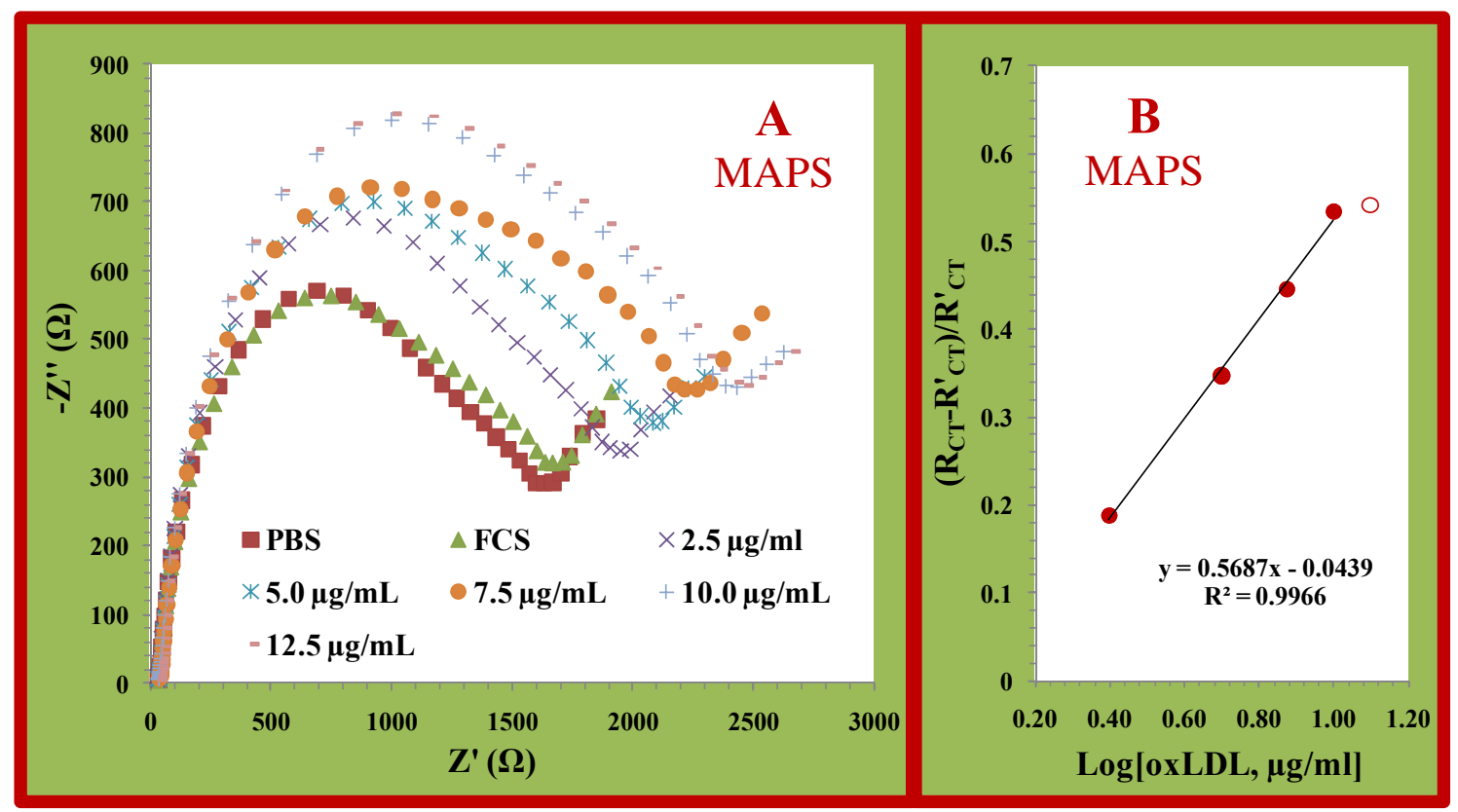

A figura à esquerda (A) mostra a primeira leitura eletroquímica realizada após incubação com PBS, com o MAPS limpo. Posteriormente, são realizadas leituras após incubação com FCS sem oxLDL, como forma de controle negativo; seguida com diluições seriadas de oxLDL, iniciando com 2,5 $\mu \mathrm{g} / \mathrm{mL}^{-1}$ até $12,5 \mu \mathrm{g} / \mathrm{mL}^{-1}$. À direitra (B) é visto gama linear da melhor resposta na curva de calibração da oxLDL diluida em FCS, que

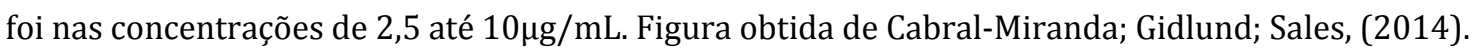

Para melhor detalhar a capacidade analítica do imunossensor, foi feito uma calibração do dispositivo com padrões de oxLDL diluídos em FCS, seguindo assim, em diluições seriadas para esta análise. A faixa de concentração de oxLDL foi de $0.0 \mu \mathrm{g} / \mathrm{mL}-1$ (FCS sem oxLDL humano) até $50 \mu \mathrm{g} / \mathrm{mL}^{-1}$. A linearidade da resposta no FCS foi 
observada de 2,5 até $10 \mu \mathrm{g} / \mathrm{mL}^{-1}$ (Tabela 3, Figura 21 A e B), com posterior saturação do MAPS, pois esse não respondia mais aos acréscimos de oxLDL.

Tabela 3. Curva de Calibração com o MAPS para detecção de oxLDL diluida em FCS.

\begin{tabular}{cccc}
\hline $\begin{array}{c}\text { Calibração da oxLDL em } \\
\text { FCS }\end{array}$ & Concentração & Tempo & Ret $(\Omega)$ \\
\hline & PBS & $15 \mathrm{~min}$ & 1.5069 \\
& FCS sem oxLDL & $15 \mathrm{~min}$ & 1.6637 \\
& $2,5 \mu \mathrm{g} / \mathrm{mL}^{-1}$ & $15 \mathrm{~min}$ & 1.9755 \\
& $5 \mu \mathrm{g} / \mathrm{mL}^{-1}$ & $15 \mathrm{~min}$ & 2.2409 \\
oxLDL & $7,5 \mu \mathrm{g} / \mathrm{mL}^{-1}$ & $15 \mathrm{~min}$ & 2.4055 \\
& $10 \mu \mathrm{g} / \mathrm{mL}^{-1}$ & $15 \mathrm{~min}$ & 2.5528 \\
& $12,5 \mu \mathrm{g} / \mathrm{mL}^{-1}$ & $15 \mathrm{~min}$ & 2.5639 \\
& $25 \mu \mathrm{g} / \mathrm{mL}^{-1}$ & $15 \mathrm{~min}$ & 2.5139 \\
& $50 \mu \mathrm{g} / \mathrm{mL}^{-1}$ & $15 \mathrm{~min}$ & 2.5339 \\
\hline
\end{tabular}

A tabela mostra os dados numéricos dos testes com o MAPS referentes à curva de calibração feita com oxLDL diluída em FCS. A primeira leitura realizada foi após incubação com PBS, ou seja, o MAPS limpo, ou controle branco. Posteriormente há leitura após incubação com FCS sem oxLDL, como forma de controle negativo; Em seguida com diluições seriadas de oxLDL, iniciado com 2,5 $\mu \mathrm{g} / \mathrm{mL}^{-1}$ até $50 \mu \mathrm{g} / \mathrm{mL}^{-1}$. 


\section{DISCUSSÃO}

0 processo de obtenção de LDL oxidada em nosso laboratório é bem caracterizado e tem sido utilizado para diversos trabalhos, desde a utilização de oxLDL para produzir anticorpos monoclonais e policlonais a trabalhos com marcadores luminescentes, como exemplo európio, para desenvolvimento de diagnósticos (ALVES et al., 2008; COURROL et al., 2007; LOURENÇO et al., 2013; RIOS et al., 2013), desta forma esse processo de obtenção e caracterização de LDL oxidada não é tão novo e atraente neste trabalho. Porém, a utilização de anticorpos monoclonais anti oxLDL sobre uma plataforma transdutora para o desenvolvimento de um imunossensor demonstrou-se um método bastante eficaz para mensurar o nível da fração de LDL oxidada (CABRALMIRANDA; GIDLUND; SALES, 2014), um parâmetro de grande importância no processo de detecção inicial da aterosclerose (FROSTEGARD, 2013; MATSUURA et al., 2014). Além disso, o uso de moléculas de oxLDL para desenvolver anticorpos plásticos, efetivamente demonstrou-se uma metodologia bastante promissora para a detecção de partículas de oxLDL circulante (CABRAL-MIRANDA et al., 2014). Hoje em dia é inegável a participação da oxLDL no processo de formação de placas aterômicas, desempenhando papel-chave na aterogênese (FROSTEGARD, 2013; MATSUURA et al., 2014). Com os vários estudos que tentam compreender a gênese da aterosclerose, acumulou-se evidências que indicam a oxLDL como importante marcador para essa cardiopatia (FRALEY; TSIMIKAS, 2006; HOLVOET et al., 2008; ISHIGAKI, 2009; ITABE et al., 2011; ITABE; UEDA, 2007; WITZTUM; STEINBERG, 1991).

Com os padrões de qualidade dos biossensores por impedância, uma classe de biossensores elétricos, este mostra ser bastante promissor para aplicações, devido à facilidade de miniaturização e operação (DANIELS; POURMAND, 2007). EIS foi a técnica mais adequada na monitoração de todo o processo de construção do biossensor, desde a formação da SAM utilizando cisteamina à aplicação prática com oxLDL diluída em soro fetal bovino. 0 aspecto de mensuração fácil e rápido promovido pela EIS é muito importante na aplicação em diagnóstico. EIS analisa a resistência e capacitância que ocorre na superfície do eletrodo, que são bastante sensíveis a eventos de ligações biológicas, tornando-se adequado para medir reações/ligações antígeno-anticorpo (OHNO et al., 2013). 
A preparação da monocamada auto-organizada utilizando apenas cisteamina foi importante para fixação e manutenção dos anticorpos sobre a superfície sensora, pois as moléculas de aminas $\left(\mathrm{NH}_{2}\right)$ foram capazes de ligarem-se às regiões carboxílicas (-COOH) dos anticorpos (porção Fc) previamente ativadas com EDAC/NHS. Este foi um passo bastante importante pela simplicidade em montar o imunossensor de forma a garantir que as regiões dos anticorpos que ligam ao antígeno estivessem livres para detectar as partículas de oxLDL. Há diversos trabalhos utilizando anticorpos para desenvolver imunossensores, pois estes garantem a manutenção das características biológicas como alto padrão de especificidade previamente adquirida que se pode obter com a utilização de anticorpos (LIPMAN et al., 2005; MADIGAN et al., 2012), porém perdem ou diminuem estas características pelo fato de não assegurar que as regiões Fab dos anticorpos estejam adequadamente expostas para detecção dos antígenos (CABRAL-MIRANDA et al., 2013). Além disso, relatam ligações aleatórias de anticorpos na plataforma de transdução de sinais, dificultando que os fragmentos Fabs mantenham-se expostos para ligação ao antígeno (CABRAL-MIRANDA et al., 2013; HINTERWIRTH et al., 2013; VEETIL; YE, 2007). Isso pode acontecer por falta de informação básica da estrutura dos anticorpos, pois mesmo ligando essas imunoglobulinas pela região Fab, poderá haver a segunda parte dos sítios de ligação ao antígeno exposta. Por obterem resultados positivos para o antígeno desejado, estes têm sido publicados como algo bastante promissor. Porém, sabe-se que o imunossensor está respondendo porque uma das regiões Fabs do anticorpo está exposta para ligar-se ao antígeno, mas não que a região Fc do anticorpo venha capturar antígenos apenas por ligações de afinidade química, ou seja, ligação amina $\left(\mathrm{NH}_{2}\right)$ carboxila $(-\mathrm{COOH})$. Outros autores relatam sistemas químicos bastante complexos para garantir a ligação do anticorpo corretamente sobre o transdutor de sinal em condições de detectar os antígenos com maior eficiência. Mas nesses casos as diversas reações envolvidas transformam-se em um processo bastante complexo e dispendioso. Além disso, a eficácia de cada etapa de modificação química é desconhecida, pelo que estes processos podem não ser tão eficazes como seria de esperar na abordagem teórica (CHU et al., 2006; HAO et al., 2009; LIU et al., 2011; TSAI; LIN, 2005; ZHANG; GRÜNER; ZHAO, 2013).

Como supracitado, têm sido desenvolvido diferentes processos de imobilização de proteínas/anticorpos fazendo o uso de SAMs. A fim de construir um biossensor, o elemento de reconhecimento é imobilizado em um eletrodo de trabalho, o qual 
traspassará as informações a um medidor de sinal químico, físico e/ou biológico, que será a unidade processadora do sinal. Esses são os padrões comuns de um biossensor, porém a eficácia do biochiip está em todo o processo de montagem, desde a escolha do elemento de reconhecimento, como um anticorpo, ao tipo de leitura que será feito durante o desenvolvimento do biossensor. Ou seja, será necessário unir múltiplos conhecimentos, como biológico, químico, físico-químico, engenharia biomédica, etc. Talvez por isso, esse trabalho obteve importantes avanços na área, pois foi desenvolvido por grupos de amplo conhecimento na área biológica e de engenharia química e biomédica.

Com as características de grande especificidade que apresentam os anticorpos monoclonais, aqui o imunossensor exibiu excelente especificidade para o antígeno alvo, mostrando ser capaz de detectar oxLDL diluída em tampão PBS, assim como diluída em amostras reais de soro fetal bovino, uma forma prática e eficiente de mimetizar a detecção de oxLDL em condições reais.

Apesar do trabalho com o imunossensor (1ํㅜ artigo em apêndice) ter gerado importantes resultados, poderia haver um maior desenvolvimento científico e tecnológico nesta pesquisa devido à formação de conhecimento do grupo envolvido.

Sabe-se que a utilização de anticorpos naturais também demonstra algumas desvantagens, como a dificuldade de produção, alto custo, além da burocracia relacionada aos comitês de ética envolvendo a utilização de animais em laboratório. Essas desvantagens, juntamente com as condições de trabalho, guiou para o desenvolvimento de novas vias de produção sintética de anticorpos, para aplicação em diagnósticos, utilizando oxLDL como moléculas.

Para isso, foi seguida a mesma linha de obtenção de anticorpos sintéticos que tem maior sucesso na tecnologia de impressão molecular (Molecular Imprinting Polymer), por utilizar uma abordagem sintética viável para a concepção de materiais de reconhecimento molecular, capazes de mimetizar os padrões de reconhecimento natural, tais como as interações antígeno-anticorpo (CHEONG; YANG; ALI, 2013; HU et al., 2013; MOREIRA et al., 2013; MUJAHID; IQBAL; AFZAL, 2013; YONGQIN; TAN; SVEC, 2013). Isso nos permitiu desenvolver artificialmente as regiões variáveis dos anticorpos com boa seletividade e especificidade para oxLDL, previamente utilizado como molde no desenvolvimento do polímero. A concepção de materiais sintéticos capazes de mimetizar processos encontrados na natureza não é recente e tornou-se uma 
importante área de investigação. Nos últimos anos, os MIPs tornaram-se importantes estratégias para criar materiais com capacidade de reconhecimento comparável aos sistemas naturais. O desenvolvimento de MIPs tem sido considerado uma técnica bastante versátil e promissora, pois tem demonstrado ser capaz de reconhecer moléculas biológicas e químicas, incluindo aminoácidos e proteínas, poluentes ambientais e alimentos contaminados (BOSSI et al., 2007; PICHON; CHAPUIS-HUGON, 2008; SCORRANO et al., 2011; TAMAYO; CASILLAS; MARTIN-ESTEBAN, 2005). A metodologia de desenvolvimento dos MIPs baseia-se basicamente na formação de um complexo entre um analito (modelo) e monômeros funcionais para formar polímeros capazes de detectar as moléculas de interesse. Após o processo de polimerização, o molde é removido do polímero que deixa locais de reconhecimento específicos complementares em tamanho, forma e a funcionalidade química. Assim, o polímero resultante reconhece e liga seletivamente apenas com as moléculas molde. As principais vantagens dos MIPs são a continuidade das características naturais, como elevada seletividade e afinidade para a molécula alvo usada no processo de impressão. Além disso, os MIPs demonstram alguns avanços em comparação com os sistemas biológicos, pois tem maior resistência física, resistência à temperatura e pressões elevadas e à inércia para ácidos, bases, íons metálicos e solventes orgânicos. Valendo apena acrescentar que o preço para serem sintetizados é muito menor do que os anticorpos naturais, além de serem possíveis de reutilização.

Apesar de todas as vantagens e dos grandes avanços na tecnologia de impressão molecular ainda é um desafio na aplicação prática para determinar moléculas circulantes em plasma natural, devido ao complexo processo em mimetizar as características naturais que um anticorpo desempenha. Para isso, o profundo conhecimento sobre os analitos que serão utilizados como moldes, além do tipo de molécula utilizada, é de extrema importância para o desempenho do sensor. Pois estruturas com padrões de reconhecimento comum poderão levar ao MIP detectar outras partículas com que tenham características em comum. Isso foi visto durante os testes utilizando os MAPSs com diferentes antígenos, onde este foi capaz de reconhecer, mesmo que levemente, LDL não oxidada. Porém, este novo conceito para construção do polímero detector de oxLDL, deverá ser bastante utilizado, não apenas para este trabalho, mas para diversos outros que desenvolva as mesmas linhas de raciocínio que 
foi utilizado para construção dos MAPSs, gerando assim, uma nova forma de concepção de anticorpos plásticos. 


\section{CONCLUSÃo}

Os diversos estudos supracitados mostram a importância das moléculas de oxLDL no processo aterogênico, porém, existe uma questão que ainda não está totalmente clara, que é o quanto a detecção de oxLDL circulante contribuirá para o diagnóstico e a evolução da aterosclerose. A aplicação desses métodos ainda se encontra em fase inicial, embora, considerando o melhor conhecimento biológico dos resultados verificados até o momento nos leva a acreditar que o conceito é promissor.

Neste trabalho, foi possível obter avanços nos caminhos para mensurar partículas de oxLDL, pois a utilização de anticorpos monoclonais em uma plataforma sensora foi um método eficaz para mensurar o nível da fração de oxLDL no soro. EIS foi uma técnica eletroquímica adequada no acompanhamento da montagem do imunossensor, assim como, na fase de testes. 0 imunossensor exibiu uma especificidade incomum para o analito alvo, sendo capaz de detectar quando presente em soluções séricas reais e em concentrações bastante baixa.

Outro avanço foi a obtenção dos resultados em tempo real, que é alcançada dentro de 20 minutos, incluindo a ligação do anticorpo ao antígeno e a leitura EIS. A imobilização do anticorpo no eletrodo também foi um processo rápido, tendo apenas algumas horas, ao contrário da incubação durante a noite, típica dos padrões de diagnósticos por ELISA. Além disso, a imobilização dos anticorpos na placa de ELISA por adsorção não garante a região Fab livre para detectar o antígeno. Levando em condição que para ter uma boa adsorção em uma placa de microtitulação, muitas vezes é necessário que a placa seja "high binding", e esse material é bastante caro, em comparação ao Au-SPE.

No geral, o imunossensor produzido é simples, rápido, barato e possível de ser portátil, mostrando grande potencial para melhorar o diagnóstico atual de detecção de oxLDL.

Além do Imunossensor, houve também o desenvolvimento de um novo processo para obter material biomimético, os anticorpos plásticos, que demonstrou superar algo que geralmente diminui a eficácia dos polímeros produzidos, que é a dependência da espessura do polímero. Para isso, foi proposto e obtido o desenvolvimento de uma camada impressa de forma invertida do anticorpo plástico SPAM, que foi a referência para desenvolver este trabalho. Isso foi comprovado com êxito com a construção dos 
MAPSs anti biomoléculas gerados pela oxidação de LDL, mesmo sendo moléculas bastante heterogêneas. O MAPS mostrou oferecer uma resposta específica para os antígenos, além de uma resposta com padrão de fácil mensuração em condições de comparar aos sistemas biológicos, como visto no Imunossensor desenvolvido também neste trabalho. No geral, este novo conceito abre um novo caminho para gerar anticorpos plásticos, criando novas perspectivas na possibilidade de gerar materiais sintéticos atuando perto de anticorpos naturais. Além disso, a seletividade observada com os MAPSs pode gerar uma nova linha de dispositivos para diagnósticos de diferentes biomoléculas de relevância clínica. 


\section{REFERÊNCIAS}

ALVES, S.; MONTEIRO, A. M.; GIDLUND, M.; NETO, A. M. F. Thermal-lens effect of native and oxidized lipoprotein solutions investigated by the Z-Scan technique. The International Journal of Atherosclerosis, v. 3, p. 33-38, 2008.

ANDICAN, G.; SEVEN, A.; UNCU, M.; CANTASDEMIR, M.; NUMAN, F. E.; BURÇAK, G. Oxidized LDL and anti-oxLDL antibody levels in peripheral atherosclerotic disease. The Scandinavian Journal of Clinical and Laboratory Investigation, v. 68, p. 473-478, 2008.

ASHRAF, M. Z.; GUPTA, N. Scavenger receptors: implications in atherothrombotic disorders. The International Journal of Biochemistry \& Cell Biology, v. 43, p. 697700, 2011.

BERTOK, T.; GEMEINER, P.; MIKULA, M.; GEMEINER, P.; TKAC, J. Ultrasensitive impedimetric lectin based biosensor for glycoproteins containing sialic acid. Microchimica Acta, v. 180, p. 151-159, 2013.

BOSSI, A.; BONINI, F.; TURNER, A. P. F.; PILETSKY, S. A. Molecularly imprinted polymers for the recognition of proteins: the state of the art. Biosensors \& Bioelectronics, v. 22, p. 1131-1137, 2007.

BOSSI, A. M.; SHARMA, P. S.; MONTANA, L.; ZOCCATELLI, G.; LAUB, O.; LEVI, R. Fingerprint-imprinted polymer: rational selection of peptide epitope templates for the determination of proteins by molecularly imprinted polymers. Anal. Chem., v. 84, p. 4036-4041, 2012.

BRADFORD, M. A. Rapid and Sensitive Method for the Quantitation of Microgram Quantities of Protein Utilizing the Principle of Protein-Dye Binding. Anal. Chem., v. 72, p. 248-254, 1976.

BRANDÃO, S. A.; IZAR, C. O.; FISCHER, S. M.; SANTOS, A. O.; MONTEIRO, C. M. PÓVOA, R. M.; HELFENSTEIN, T.; CARVALHO, A. C.; MONTEIRO, A. M.; RAMOS, E.; GIDLUND, M.; FIGUEIREDO NETO, A. M.; FONSECA, F. A. Early increase in autoantibodies against human oxidized low-density lipoprotein in hypertensive patients after blood pressure control. Am. J. Hypertens., v. 23, p. 208-214, 2010.

CABRAL-MIRANDA, G.; DE JESUS, J. R.; OLIVEIRA, P. R. S.; BRITTO, G. S. G.; PONTES-DECARVALHO, L. C.; DUTRA R. F.; ALCÂNTARA-NEVES, N. M. Detection of parasite antigens in Leishmania infantum-infected spleen tissue by monoclonal antibody-, piezoelectricbased immunosensors. J. Parasitol., 2013.

\footnotetext{
* De acordo com: ASSOCIAÇÃO BRASILEIRA DE NORMAS TÉCNICAS. NBR 6023: informação e documentação: referências: elaboração. Rio de Janeiro, 2002.
} 
CABRAL-MIRANDA, G.; GIDLUND, M.; SALES, M. G. F. Backside-surface imprinting as a new strategy to generate specific plastic antibody materials. Journal of Materials Chemistry B, v. 2, p. 3087 - 3095, 2014.

CABRAL-MIRANDA, G.; YAMASHIRO-KANASHIRO, E. H. G.; GIDLUNDA, M.; SALES, M.G.F. Specific label-free and real-time detection of oxidized low density lipoprotein (oxLDL) using an immunosensor with three monoclonal antibodies. Journal of Materials Chemistry B, v. 2, p. 477-484, 2014.

CASTELLI, W. P.; GARRISON, R. J.; WILSON, P. W. F.; ABBOTT, R. D.; KALOUSDIAN, S.; KANNEL, W. B. Incidence of coronary heart disease and lipoprotein cholesterol levels. JAMA, v. 256, p. 2835-2838, 1986.

CHEN, L.; XU, S.; LI, J. Recent advances in molecular imprinting technology: current status, challenges and highlighted applications. Chemical Society Reviews, v. 40, p. 2922-2942, 2011.

CHEN. R. J.; BANGSARUNTIP, S.; DROUVALAKIS, K. A.; KAM, N. W. S.; SHIM, M.; KIM, Y.; LI, W.; UTZ, P. J.; DAI, H. Noncovalent functionalization of carbon nanotubes for highly specific electronic biosensors. PNAS, v. 100, p. 4984-4989, 2003.

CHEONG, W. J.; YANG, S. H.; ALI, F. Molecular imprinted polymers for separation science: A review of reviews. J. Sep. Sci., v. 36, p. 609-628, 2013.

CHOWDHURY, R.; WARNAKULA, S.; KUNUTSOR, S.; CROWE, F.; WARD, H. A.; JOHNSON.; FRANCO, O. H.; BUTTERWORTH, A. S.; FOROUHI, N. G.; THOMPSON, S. G.; KAY-TEE, K.; MOZAFFARIAN, D.; DANESH, J.; ANGELANTONIO, E. Association of dietary, circulating, and supplement fatty acids with coronary risk: a systematic review and meta-analysis. Ann. Intern. Med., v. 160, p. 398-406, 2014.

CHU, X.; ZHAO, Z. L.; SHEN, G. L.; YU R. Q. Quartz crystal microbalance immunoassay with dendritic amplification using colloidal gold immunocomplex. Sensor. Actuat. B, v. 114, p. 696-704, 2006.

COURROL, L. C.; MONTEIRO, A. M.; SILVA, O. F. R.; GOMES, L.; VIEIRA JR., N. D.; GIDLUND, M. A.; FIGUEIREDO NETO, A. M. Novel fluorescent probe for low density lipoprotein, based on the enhancement of Europium emission band. Optics Express, v. 15, p. 7066-7074, 2007.

CRUCET, M.; WÜST, S.J.A.; SPIELMANN, P.; LÜSCHER, T.F.; WENGER, R.H.; MATTER, C.M. Hypoxia enhances lipid uptake in macrophages: role of the scavenger receptors Lox1, SRA, and CD36. Atherosclerosis, v. 229, p. 110-117, 2013.

CUNnINGHAM, B. T. Label-free biosensors: an introduction. Cambridge University Press, v. 5, 2008. 
DAMASCENO, N. R. T.; GIDLUND, M.; GOTO, H.; DIAS, C. T. S.; OKAWABATA, F. S.; ABDALLA, D. S. P. Casein and Soy Protein Isolate in Experimental Atherosclerosis: Influence on Hyperlipidemia and Lipoprotein Oxidation. Annals of Nutrition and Metabolism, v. 45, p. 38-46, 2001.

DANIELS, J. S.; POURMAND, N. Label-free impedance biosensors: opportunities and challenges. Electroanalysis, v. 19, p. 1239-1257. 2007.

DUTRA, R. F.; MACIEL NETO, J. O.; FONTANA, E. Surface plasmon resonance imagin applied to immunosensor. SPIE, v. 2, p. 128-135, 2001.

DUTRA, R. F.; COELHO, G. D.; SILVA, V. L.; LEDINGHAM, W. M.; LIMA-FILHO, J. L. A reusable amperometric biosensor based on a novel silver-epoxy electrode for immunoglobulin detection. Biotechnology Letters, v. 22, p. 579-583. 1999.

EHARA, S.; UEDA, M.; NARUKO, T.; HAZE, K.; ITOH, A.; OTSUKA, M.; KOMATSU, R.; MATSUO, T.; ITABE, H.; TAKANO, H.; TSUKAMOTO, Y.; YOSHIYAMA, M.; TAKEUCHI, K.; YOSHIKAWA, J.; BECKER, A. E. Elevated Levels of Oxidized Low Density Lipoprotein Show a Positive Relationship With the Severity of Acute Coronary Syndromes. Circulation, v. 103, p. 1955-1960, 2001.

FAN, J.; WATANABE, T. Inflammatory reactions in the pathogenesis of atherosclerosis. Journal of Atherosclerosis and Thrombosis, v. 10, p. 63-71, 2003.

FERNVIK, E. C.; KETELHUTH, D. F.; RUSSO, M.; GIDLUND, M. The Autoantibody Repertoire Against Copper-or Macrofage-Modified LDL Differs in Normolipidemics and Hypercholesterolemic Patients. J. Clin. Immunol. v. 24, p. 170-176, 2004.

FRALEY A. E.; TSIMIKAS, S. "Clinical applications of circulating oxidized low-density lipoprotein biomarkers in cardiovascular disease". Current Opinion in Lipidology, v. 17, p. 502-509, 2006.

FRANÇOSO, L. M.; COATES, V. Anatomicopathological Evidence of the Beginning of Atherosclerosis in Infancy and Adolescence. Arquivos Brasileiros de Cardiologia. v. 78, p. 131-136, 2002.

FROSTEGARD, J. Immunity, atherosclerosis and cardiovascular disease. BMC Medicine, V. 11, p. 117-130, 2013.

FUKUMOTO, M.; SHOJI, T.; EMOTO, M.; KAWAGISHI, T.; OKUNO, Y.; NISHIZAWA, Y. Antibodies against oxidized LDL and carotid artery intima-media thickness in a healthy population. Arterioscler Thromb Vasc Biol., v. 20, p. 703-707. 2000

GIANNINI, S. D. Aterosclerose/dislipidemias: clínica e terapêutica: fundamentos práticos. São Paulo: BG Cultural, 1998. p. 1-10. 
GIDLUND, M.; DAMASCENO, N. R. T.; ABDALLA, D. S. P.; GOTO, H. Monoclonal antibodies against low density lipoprotein with various degrees of oxidative modifications. Braz. J. Med. Biol. Res., v. 29, p. 1625-1628, 1996.

GOLDSTEIN, J. L.; HO, Y. K.; BASU, S. K.; BROWN, M. S. Binding site on macrophages that mediates uptake and degradation of acetylated low density lipoprotein, producing massive cholesterol deposition. PNAS, v. 76, p. 333-337, 1979.

GOODING, J. J.; CIAMPI, S. The molecular level modification of surfaces: from selfassembled monolayers to complex molecular assemblies. Chemical Society Reviews, v. 40, p. 2704-2718, 2011.

GRADINARU, D.; BORSA, C.; IONESCU, C.; MARGINA, D. Advanced oxidative and glycoxidative protein damage markers in the elderly with type 2 diabetes. J. Proteomics, v. 92, p. 313-322, 2013.

GUO, M.; CHEN, J.; LIU, D.; NIE, L.; YAO, S. Electrochemical characteristics of the immobilization of calf thymus DNA molecules on multi-walled carbon nanotubes. Bioelectrochemistry, v. 62, p. 29-35, 2004.

HAO, R.; WANG, D.; ZHANG, X.; ZUO, G.; WEI, H.; YANG, R.; ZHANG, Z.; CHENG, Z.; GUO, Y.; CUI, Z.; ZHOU, Y. Rapid detection of Bacillus anthracis using monoclonal antibody functionalized QCM sensor. Biosensors \& Bioelectronics, v. 24, p. 1330-1335, 2009.

HANSSON, G. K.; LIBBY, P. The immune response in atherosclerosis: a double-edged sword. Nature Reviews Immunology, v. 6, p. 508-519, 2006.

HANSSON, G. K.; ROBERTSON, A. K.; SODERBERG-NAUCLER, C. Inflammation and atherosclerosis. Annu. Rev. Pathol., v. 1, p. 297-329, 2006.

HAYDEN, O.; LIEBERZEIT, P. A.; BLAAS, D.; DICKERT, F.L. Artificial antibodies for bioanalyte detection - sensing viruses and proteins. Adv. Funct. Mater., v. 16, p.12691278, 2006.

HINTERWIRTH, H.; STÜBIGER, G.; LINDNER, W. E.; LAMMERHOFER, M. Gold Nanoparticle-Conjugated Anti-Oxidized Low-Density Lipoprotein Antibodies for Targeted Lipidomics of Oxidative Stress Biomarkers. Anal. Chem., v. 85, p. 8376-8384, 2013.

HOLVOET, P.; LEE, D. H.; STEFFES, M.; GROSS, M.; JACOBS Jr., D. R. Association between circulating oxidized low-density lipoprotein and incidence of themetabolic syndrome. JAMA, v. 299, p. 2287-2293, 2008.

HOLVOET, P.; VANHAECKE, J.; JANSSENS, S.; VAN DE WERF, F.; COLLEN, D. Oxidized LDL and malondialdehyde-modified LDL in patients with acute coronary syndromes and stable coronary artery disease. Circulation, v. 98, p. 1487-1494,1998. 
HU, Y.; PAN, J.; ZHANG, K.; LIAN, H.; LI, G. Novel applications of molecularly-imprinted polymers in sample preparation. Trends in Analytical Chemistry, v. 43, p. 37-52, 2013.

ISHIGAKI, Y.; OKA, Y.; KATAGIRI, H. "Circulating oxidized LDL: a biomarker and a pathogenic factor". Current Opinion in Lipidology, v. 20, p. 363-369, 2009.

ITABE, H. Oxidized phospholipids as a new landmark in atherosclerosis. Progress in Lipid Research, v. 37, p. 181-207, 1998.

ITABE H.; UEDA, M. Measurement of plasma oxidized lowdensity lipoprotein and its clinical implications. J. Atheros and Thromb, v. 14, p. 1-11, 2007.

ITABE, H.; OBAMA, T.; KATO, R. The Dynamics of Oxidized LDL during Atherogenesis. Journal of Lipids, v. 211, p. 1-9, 2011.

ITABE, H.; YAMAMOTO, H.; IMANAKA, T.; SHHAMURA, K.; UCHIYAMA, H.; KIMURA, L.; SANAKA, T.; HAT, Y.; TAKANO, T. Sensitive detection of oxidatively modified low density lipoprotein using a monoclonal antibody. Journal of Lipid Research, v. 37, p. 45-53, 1996.

JANSEN, H.; GHANEM, H.; KUYPERS, J. H.; BIRKENHAGER, J. C. Autoantibodies against malondialdehyde-modified LDL are elevated in subjects with an LDL subclass pattern B. Atherosclerosis, v. 115, p. 255-262, 1995.

JIANG, K.; SCHADLER, L. S.; SIEGEL, R. W.; ZHANG, X.; ZHANG, H.; TERRONES, M. Protein immobilization on carbon nanotubes via a two-step process of diimide-activated amidation. Journal of Materials Chemistry, v. 14, p. 37-39, 2004.

KASSI, E.; DALAMAGA, M.; FAVIOU, E.; HROUSSALAS, G.; KAZANIS, K.; NOUNOPOULOS, C. $\mathrm{H}$. Circulating oxidized LDL levels, current smoking and obesity in postmenopausal women. Atherosclerosis, v. 205, p. 279-283, 2009.

KÖHLER, G.; MILSTEIN, C. Continuous cultures of fused cells secreting antibody of predefined specificity. Nature, v. 256, p. 495-497,1975.

KOHNO, H.; SUESHIGE, N.; OGURI, K.; IZUMIDATE, H.; MASUNARI, T.; KAWAMURA, M.; ITABE, H.; TAKANO, T.; HASEGAWA, A.; NAGAI, R. Simple and practical sandwich-type enzyme immunoassay for human oxidatively modified low density lipoprotein using antioxidized phosphatidylcholine monoclonal antibody and antihuman apolipoprotein-B antibody. Clinical Biochemistry, v. 33, p. 243-253, 2000.

KZHYSHKOWSKA, J.; NEYEN, C.; GORDON, S. Role of macrophage scavenger receptors in atherosclerosis. Immunobiology, v. 217, p. 492-502, 2012.

LEPAGE, S.; NIGON, F.; BONNEFONT-ROUSSELOT, D.; ASSOGBA, U.; GOULINET, S.; CHANCHARME, L.; DELATTRE, J.; BRUCKERT, E.; CHAPMAN, M. J. Oxidizability of 
atherogenic low-density lipoprotein subspecies in severe familial hypercholesterolemia: impact of long-term low-density lipoprotein apheresis. JCPT, v. 5, p. 87-103, 2000.

LIPMAN, N. S.; JACKSON, L. R.; TRUDEL, L. J.; WEIS-GARCIA F. Monoclonal Versus Polyclonal Antibodies: Distinguishing Characteristics, Applications, and Information Resources. ILAR Journal, v. 46, p. 258-268, 2005.

LIU, G.; CHEN, H.; PENG, H.; SONG, S.; GAO, J.; LU, J.; DING, M.; LI, L.; REN, S.; ZOU, Z.; FAN, C. A carbon nanotube-based high-sensitivity electrochemical immunosensor for rapid and portable detection of clenbuterol. Biosensors \& Bioelectronics, v. 28, p. 308-313, 2011.

LOURENÇO, A. V. S.; KODAIRA, C. A.; RAMOS-SANCHEZ, E. M.; FELINTO, M. C. F. C.; GOTO, H.; GIDLUND, M.; MALTA, O. L.; BRITO, H. F. Luminescent material based on the [Eu(TTA)3(H20)2] complex incorporated into modified silica particles for biological applications. J of Inorg Bioch., v. 123, p. 11-17, 2013.

LOWRY, O. H.; ROSEBROUGH, N. J.; FARR, A. L.; RANDALL, R.; J. Protein measurement with the Folin phenol reagent. J Biol Chem., v. 193, p. 265-275, 1951.

MALHOTRA, B. D.; CHAUBEY, A.; SINGH, S. P. Prospects of conducting polymers in biosensors. Anal. Chim. Acta., v. 578, p. 59-74, 2006.

MADIGAN, M. T.; MARTINKO, J. M.; STAHL, D. A.; CLARK, D. P. Immune mechanisms. In: BROCK. Biology of microorganisms. 13th ed. Benjamin Cummings, Pearson Education, p. 850, 2012. Chapter 30, p. 850.

MATSUURA, E.; ATZENI, F.; SARZI-PUTTINI, P.; TURIEL, M.; LOPEZ, L.R.; NURMOHAMED, M. T. Is atherosclerosis an autoimmune disease? BMC Medicine, v. 12, p. 47-52, 2014.

MAXFIELD, F. R.; TABAS, I. Role of cholesterol and lipid organization in disease. Nature, V. 438, p. 612-621, 2005.

MANOLIO, T. A.; PEARSON, T. A.; WENGER, N. K.; BARRETT-CONNOR, E.; PAYNE, G. H.; HARLAN, W. R. Cholesterol and heart disease in older persons and women review of an NHLBI workshop. Annals of Epidemiology, v. 2, p. 161-176, 1992.

MILLER, Y. I.; VIRIYAKOSOL, S.; BINDER, C. J.; FERAMISCO, J. R.; KIRKLAND, T. N.; WITZTUM, J. L. Minimally Modified LDL Binds to CD14, Induces macrophage spreading via TLR4/MD-2, and inhibits phagocytosis of apoptotic cells. J. Biol. Chem., v. 278, p. $1561-1568,2003$.

MOREIRA, F. T. C.; SHARMA, S.; DUTRA, R. A. F.; NORONHA, J. P. C.; CASS, A. E. G.; SALES, M. G. F. Smart plastic antibody material (SPAM) tailored on disposable screen printed 
electrodes for protein recognition: application to myoglobin detection. Biosensors \& Bioelectronics, v. 45, p. 237-244, 2013.

MUJAHID, A.; IQBAL, N.; AFZAL, A. Bioimprinting strategies: from soft lithography to biomimetic sensors and beyond. Biotechnology Advances, v. 31, p. 1435-1447, 2013.

MURPHY, L. Biosensors and bioelectrochemistry. Bioinorganic Chemistry, v. 10, p. 177-184, 2006.

NARUKO, T.; UEDA, M.; EHARA, S.; ITOH, A.; HAZE, K.; SHIRAI, N.; IKURA, Y.; OHSAWA, M.; ITABE, H.; KOBAYASHI, Y.; YAMAGISHI, H.; YOSHIYAMA, M.; YOSHIKAWA, J.; BECKER, A. E. Persistent High Levels of Plasma Oxidized Low-Density Lipoprotein After Acute Myocardial Infarction Predict Stent Restenosis. ATVB, v. 26, p. 877-883, 2006.

NGUNJIRI, J. N.; STARK, D. J.; TIAN, T.; BRIGGMAN, K. A.; GARNO, J. C. Immobilization of proteins on carboxylic acid functionalized nanopatterns. Analytical and Bioanalytical Chemistry, v. 405, p. 1985-1993, 2013.

NISSEN, S. E.; TUZCU, E. M.; SCHOENHAGEN, P.; CROWE, T.; SASIELA, W. J.; TSAI, J.; ORAZEM, J.; MAGORIEN, R. D.; O'SHAUGHNESSY, C.; GANZ, P. Statin Therapy, LDL Cholesterol, C-Reactive Protein, and Coronary Artery Disease. N. Engl. J. Med., v. 352, p. 29-38, 2005.

OBAMA, T.; KATO, R.; MASUDA, Y.; TAKAHASHI, K.; AIUCHI, T.; ITABE, H. Analysis of modified apolipoprotein B-100 structures formed in oxidized low-density lipoprotein using LC-MS/MS. Proteomics, v. 7, p. 2132-2141, 2007.

OHNO, R.; OHNUKI, H.; WANG, H.; YOKOYAMA, T.; ENDO, H.; TSUYA, D.; IZUMI, M. Electrochemical impedance spectroscopy biosensor with interdigitated electrode for detection of human immunoglobulin A. Biosensors and Bioelectronics, v. 40, p. 422426, 2013.

PEJKOV, H.; KEDEV, S.; PANOV, S.; SRBINOVSKA-KOSTOVSKA, E.; LANG, I. Atherosclerosis of coronary blood vessels - local or systemic inflamation? Prilozi, v. 34, p. 5-11, 2013.

PIARUlli, F.; LAPOllA, A.; SARTORE, G.; ROSSETTI , C.; BAX, G.; NOALE, M. Autoantibodies against oxidized LDLs and atherosclerosis in type 2 diabetes. Diabetes Care, v. 28, p. 653-657, 2005.

PICHON, V.; CHAPUIS-HUGON, F. Role of molecularly imprinted polymers for selective determination of environmental pollutants--a review. Anal. Chim. Acta, v. 622, p. 48-61, 2008.

POLYAKOV, M. V. Adsorption properties and structure of silica gel. Zhurnal Fizicheskoi Khimii, v. 2, p. 799-905, 1931. 
POMA, A.; TURNER, A. P. F.; PILETSKY, S. A. Advances in the manufacture of MIP nanoparticles. Trends Biotechnol., v. 28, p. 629-637, 2010.

REDDY, S. M.; SETTE, G.; PHAN, Q. Electrochemical probing of selective haemoglobin binding in hydrogel-based molecularly imprinted polymers. Electrochimica Acta, v. 56, p. 9203-9208, 2011.

RIOS, F. J.; KOGA, M. M.; PECENIN, M.; FERRACINI, M.; GIDLUND, M.; JANCAR, S. Oxidized LDL induces alternative macrophage phenotype through activation of CD36 and PAFR. Mediators of Inflammation, v. 2013, p. 1-8, 2013

ROSS, R. Atherosclerosis- an inflammatory diseases. N. Engl. J. Med., v. 340, p. 115-126, 1999.

ROSS, R. The pathogenesis of atherosclerosis: a perspective for the 1990s. Nature. v. 362, p. 801-809, 1993.

SAERENS, D.; HUANG, L.; BONROY, K.; MUYLDERMANS, S. Antibody Fragments as Probe in Biosensor Development. Sensors, v. 8, p. 4669-4686, 2008.

SAKURAI, T.; WADA, N.; TAKAHASHI, Y.; ICHIKAWA, A.; IKUTA, A.; FURUMAKI, H.; SHUPING, H.; JIN, S.; TAKEDA, S.; FUDA, H.; FUJIKAWA, M.; SHIMIZU, C.; NAGASAKA, H.; FURUKAWA, H.; KOBAYASHI, S.; CHIBA, H. Immunological detection of large oxidized lipoproteins in hypertriglyceridemic serum. Ann Clin Biochem, (online), 2013.

SANTOS, A. O.; FONSECA, F. A.; FISCHER, S. M.; MONTEIRO, C. M.; BRANDÃO, S. A.; PÓVOA, R. M. High circulating autoantibodies against human oxidized low-density lipoprotein are related to stable and lower titers to unstable clinical situation. Clin. Chim. Acta, v. 406, p. 113-118, 2009.

SCORRANO, S.; MERGOLA, L.; DEL SOLE, R.; VASAPOLLO, G. Synthesis of Molecularly Imprinted Polymers for Amino Acid Derivates by Using Different Functional Monomers. Int. J. Mol. Sci. v. 12, p. 1735-1743, 2011.

SHOJI, T.; NISHIZAWA, Y.; FUKUMOTO, M.; SHIMAMURA, K.; KIMURA, J.; KANDA, H.; EMOTO, M.; KAWAGISHI, T.; MORII, H. Inverse relationship between circulating oxidized low density lipoprotein (oxLDL) and anti-oxLDL antibody levels in healthy subjects. Atherosclerosis, v. 148, p. 171-177, 2000.

SOLTESZ, P.; VERES, K.; LACZIK, R.; DER, H.; CSIPO, I.; TIMAR, O.; SZOMJAK, E.; SZEGEDI, G.; SZODORAY, P. Evaluation of antibodies to oxidized low-density lipoprotein and assessment of $\mathrm{C}$-reactive protein in acute coronary syndrome and stable coronary artery disease. Thromb Haemost., v. 98, p. 413-419, 2007.

STEINBRECHER, U. P.; PARTHASARATHY, S., LEAKE, D. S.; WITZTUM, J. L.; STEINBERG D. Modification of low density lipoprotein by endothelial cells involves lipid peroxidation 
and degradation of low density lipoprotein phospholipids. Proceedings of the National Academy of Sciences of the USA, v. 81, p. 3883-3887, 1984.

STOCKER, R.; KEANEY JR, J. F. Role of Oxidative Modifications in Atherosclerosis. Physiol. Rev., v. 84, p. 1381-1478, 2003.

TAKEDA, S.; HUI, S. P.; FUKUDA, K.; FUDA, H.; JIN, S.; SAKURAI, T.; ISHII A.; MUKASA, K.; SUEOKA, K.; CHIBA, H. Detection of oxidized LDL using a carbon nanotube electrode. Sensor. Actuat. B.,v. 166, p. 833-836, 2012.

TAKEUCHI, T.; HISHIYA, T. Molecular imprinting of proteins emerging as a tool for protein recognition. Org. Biomol. Chem.,v. 21, p. 2459-2467, 2008.

TAMAYO, F. G.; CASILLAS, J. L.; MARTIN-ESTEBAN, A. Clean-up of phenylurea herbicides in plant sample extracts using molecularly imprinted polymers. Anal. and Bioanal. Chemistry, v. 381, p. 1234-1240, 2005.

TSAI, W. C.; LIN, I. C. Development of a piezoelectric immunosensor for the detection of alpha-fetoprotein. Sensors Actuators B, v. 106, p. 455-460, 2005.

TSIMIKAS, S.; AIKAWA, M.; MILLER JR., F.J.; MILLER, E. R.; TORZEWSKI, M.; LENTZ, S. R.; BERGMARK, C.; HEISTAD, D. D.; LIBBY, P.; WITZTUM, J. L. Increased plasma oxidized phospholipid:apolipoprotein B-100 ratio with concomitant depletion of oxidized phospholipids from atherosclerotic lesions after dietary lipid-lowering: a potential biomarker of early atherosclerosis regression. Arteriosclerosis, Thrombosis, and Vascular Biology, v. 27, p. 175-181, 2007.

TURNER, N. W.; JEANS, C. W.; BRAIN, K. R.; ALLENDER, C. J.; HLADY, V.; BRITT, D. W. From 3D to 2D: a review of the molecular imprinting of proteins. Biotechnol. Prog., $\mathrm{V}$. 22, p. 1474-1489, 2006.

UNO, M.; KITAZATO, K. T.; NISHI, K.; ITABE, H.; NAGAHIRO, S. Raised plasma oxidised LDL in acute cerebral infarction. Journal of Neurology, Neurosurgery and Psychiatry, v. 74, p. 312-316, 2003.

VAN TITS, L.; de GRAAF J.; HAK-LEMMERS, H.; BREDIE, S.; DEMARKER, P.; HOLVOET, P.; STALENHOEF, A. Increased Levels of Low-Density Lipoprotein Oxidation in Patients with Familial Hypercholesterolemia and in End-Stage Renal Disease Patients on Hemodialysis. Lab Invest., v. 83, p. 13-21, 2003.

VASAPOLLO, G.; SOLE, R. D.; MERGOLA, L.; LAZZOI, M. R.; SCARDINO, A.; SCORRANO, S.; MELE, G. Molecularly imprinted polymers: present and future prospective. Int. J. Mol. Sci., v. 12, p. 5908-5945, 2011.

VEETIL, J. V.; YE, K. Development of immunosensors using carbon nanotubes. Biotechnol. Prog., v. 23, p. 517-531, 2007. 
VERHEYEN, E.; SCHILLEMANS, J. P.; VAN WIJK, M.; DEMENIEX, M. A.; HENNINK, W. E.; VAN NOSTRUM, C. F. Challenges for the effective molecular imprinting of proteins. Biomaterials, v. 32, p. 3008-3020, 2011.

WITZTUM, J. L. Role of oxidized LDL in atherogenesis. Br. Heart J., v. 69, p. 512-522, 1993.

WITZTUM J. L.; STEINBERG, D. Role of oxidized low density lipoprotein in atherogenesis. J. Clin. Invest., v. 88, p. 1785-1792, 1991.

WORLD HEALTH ORGANIZATION (WHO). Global Atlas on cardiovascular disease prevention and control. Section A, p. 1-54, 2011.

WULFF, G.; SARHAN, A. Use of polymers with enzymeanalogous structures for the resolution of racemates. Angew. Chem. Int. Ed. Engl., v. 11, p. 341, 1972.

YAN-JUN, X.; TAPPIA, P. S.; NEKI, N. S.; DHALLA, N. S. Prevention of diabetes-induced cardiovascular complications upon treatment with antioxidants. Heart Fail Rev., v. 19, p. 113-121, 2014.

YE, L.; MOSBACH, K. Molecular Imprinting: Synthetic Materials As Substitutes for Biological Antibodies and Receptors. Chem. Mater., v. 20, p. 859-868, 2008.

YONGQIN, Lv.; TAN, T.; SVEC, F. Molecular imprinting of proteins in polymers attached to the surface of nanomaterials for selective recognition of biomacromolecules. Biotechnology Advances, v. 31, p. 1172-1186, 2013.

YUAN, Y. R.; YUAN, R.; CHAI, Y. Q.; ZHUO, Y.; MIAO, X. M. Electrochemical amperometric immunoassay for carcinoembryonic antigen based on bi-layer nano-Au and nickel hexacyanoferrates nanoparticles modified glassy carbon electrode. J. Electroanal. Chem., v. 626, p.6-13, 2009.

ZARATIN, A.; GIDLUND, M.; BOSCHCOV, P.; CASTILHO, L.; de FARIA, E. C. Antibodies against oxidized low-density lipoprotein in normolipidemic smokers. Am. J. Cardiol., v. 90, p. 651-653, 2002.

ZHANG, H.; GRÜNER, G.; ZHAO Y. J. Recent advancements of graphene in biomedicine. J. Mater. Chem. B, v. 1, p. 2542-2567, 2013.

ZHAO, H.; JU, H. Multilayer membranes for glucose biosensing via layer-by-layer assembly of multiwall carbon nanotubes and glucose oxidase. Anal. Biochem., v. 350, p. 138-144, 2006. 


\section{APÊNDICES}

APÊNDICE A - 1ํAtigo: Specific label-free and real-time detection of oxidized low density lipoprotein (oxLDL) using na immunosensor with three monoclonal antibodies 


\title{
Specific label-free and real-time detection of oxidized low density lipoprotein (oxLDL) using an
}

Cite this: J. Mater. Chem. B, 2014, 2, 477

\author{
Gustavo Cabral-Miranda, ${ }^{\text {abc }}$ E. H. G. Yamashiro-Kanashiro, ${ }^{c}$ Magnus Gidlund ${ }^{a}$ \\ and M. Goreti F. Sales ${ }^{\star b}$
}

Increased levels of plasma oxLDL, which is the oxidized fraction of Low Density Lipoprotein (LDL), are associated with atherosclerosis, an inflammatory disease, and the subsequent development of severe cardiovascular diseases that are today a major cause of death in modern countries. It is therefore important to find a reliable and fast assay to determine oxLDL in serum. A new immunosensor employing three monoclonal antibodies (mAbs) against OxLDL is proposed in this work as a quick and effective way to monitor oxLDL. The oxLDL was first employed to produce anti-oxLDL monoclonal antibodies by hybridoma cells that were previously obtained. The immunosensor was set-up by selfassembling cysteamine (Cyst) on a gold ( $\mathrm{Au}$ ) layer (4 $\mathrm{mm}$ diameter) of a disposable screen-printed electrode. Three mAbs were allowed to react with $\mathrm{N}$-hydroxysuccinimide (NHS) and ethyl(dimethylaminopropyl)carbodiimide (EDAC), and subsequently incubated in the Au/Cys. Albumin from bovine serum (BSA) was immobilized further to ensure that other molecules apart from oxLDL could not bind to the electrode surface. All steps were followed by various characterization techniques such as electrochemical impedance spectroscopy (EIS) and square wave voltammetry (SWV). The analytical operation of the immunosensor was obtained by incubating the sensing layer of the device in oxLDL for 15 minutes, prior to EIS and SWV. This was done by using standard oxLDL solutions prepared in foetal calf serum, in order to simulate patient's plasma with circulating oxLDL. A sensitive response was observed from 0.5 to $18.0 \mu \mathrm{g} \mathrm{mL}^{-1}$. The device was successfully applied to determine the oxLDL

Received 28th July 2013

Accepted 4th November 2013

DOI: $10.1039 / \mathrm{c} 3 \mathrm{tb} 21048 \mathrm{k}$

www.rsc.org/MaterialsB fraction in real serum, without prior dilution or necessary chemical treatment. The use of multiple monoclonal antibodies on a biosensing platform seemed to be a successful approach to produce a specific response towards a complex multi-analyte target, correlating well with the level of oxLDL within atherosclerosis disease, in a simple, fast and cheap way.

\section{Introduction}

Coronary heart disease is the result of inadequate circulation of blood in the myocardium and occurs when the coronary arteries become partially blocked or obstructed. ${ }^{1}$ Atherosclerosis is the main cause of cardiovascular disease and it is an inflammatory condition characterized by thickening and hardening of the arterial wall, with the deposition of fatty substances, cholesterol, cellular waste products and other substances, leading to plaque formation, called atheroma, and causing hemodynamic alteration. ${ }^{2,3}$ Furthermore, an atheroma, in later stages, can totally or partially block blood flow through the arteries and

\footnotetext{
${ }^{a}$ Laboratory of Immunophysiopathology, Department of Immunology at the Institute of Biomedical Sciences, University of Sao Paulo, Brazil

${ }^{b}$ BioMark/ISEP, School of Engineering, Polytechnic Institute of Porto, R. Dr. António Bernardino de Almeida, 431, 4200-072 Porto, Portugal.E-mail: goreti.sales@gmail. com; Fax: +351228 321 159; Tel: +351228 340544

'Tropical Medicine Institute, University of São Paulo, Brazil
}

cause plaque rupture with haemorrhage and development of thrombosis, which are the main causes of morbidity and mortality in westernized countries, leading to a considerable economic overload..$^{3-5}$

LDL is the main carrier of cholesterol in the blood and exerts important physiological and cellular function and regulation of metabolic pathways. However, a large amount of clinical evidence, as well as epidemiological studies, correlate high concentrations of plasma cholesterol and increased risk of cardiovascular disease. ${ }^{6}$ Furthermore, increased plasma levels of LDL, especially its oxidized form (oxLDL), are associated with atherosclerosis. oxLDL promotes vascular dysfunction by exerting direct cytotoxicity towards endothelial cells and increases chemotactic properties for monocytes and macrophages and consequent transformation into foam cells, which contribute to atherogenesis. ${ }^{7-10}$

Although the oxLDL level in circulating plasma is commonly recognized as an important predictive marker of risk of cardiovascular events, simple and cheap assays for oxLDL level 
determination remain to be developed. There are many ways to determine oxLDL in the blood by ELISA (enzyme-linked immunosorbent assay) methods, such as employing different monoclonal and polyclonal antibodies that are capable of detecting oxLDL fractions involved in the atherogenesis. ${ }^{11-13}$ Alternative methods employ anti-oxLDL Abs conjugated to gold nanoparticles and subsequent detection by liquid chromatography/tandem-mass spectrometry (LC-MS/MS) ${ }^{13}$ or proteoheparan sulfate coated hydrophobic silica for subsequent ellipsometry readings. ${ }^{14-16}$ These two approaches are however unsuitable for applications in point-of-care diagnosis, also being coupled to expensive equipment.

Despite the differences observed between different ELISA procedures used for oxLDL determination, which are directly correlated with the biological and clinical significance of oxLDL measures, ${ }^{\mathbf{1 1}}$ the gold standard methods to determine oxLDL are still carried out using commercial ELISA kits. These methods are also very expensive and time consuming, requiring highly qualified personnel and special handling procedures/storage conditions. Therefore, novel approaches with a simple procedure and low cost are highly necessary and would be greatly appreciated.

Biosensors could offer advantageous features compared to diagnostic tools like ELISA, due to their sensitivity, selectivity, simplicity, speed, low-cost, portability, and automation feasibility. ${ }^{17-23}$ An easy approach towards biosensing design in this context is to include an antibody as a biological recognition element, usually recognized as an immunosensor.

Although immunosensors display several attractive features, there are two major difficulties hindering the performance of immunosensing devices. One difficulty is to ensure that the Fragment antigen-binding (Fab) is suitably exposed for antigen binding. Many studies report random binding of Abs, preventing many of the Fab fragments in the receptor platform from binding to the antigen. To solve this problem, several authors reported complex chemical systems driving the Abs connected to the solid support in a specific orientation, ${ }^{24-28}$ but in this case the many reactions involved turn this a very complex process. Also, the effectiveness of each stage of chemical modification conditioning such an orientation is unknown, for which this process may not be as effective as expected in the theoretical approach.

The other major difficulty is to obtain a specific response towards the antigen. The use of monoclonal antibodies (mAb) may turn out to be a successful approach to obtain such a specific response towards a selected target antigen. ${ }^{28-31}$ This is particularly relevant when the analyte is not a single structure but a mixture of several/complex target compounds. This is the case for oxLDL, obtained by random oxidation of native LDL.

Thus, this work proposes the development of an immunosensor for oxLDL by employing simple chemistry strategies that ensure suitable orientation of the mAb on top of a gold sensing layer of screen-printed electrodes (SPEs). Furthermore, three different mAbs were merged in the same platform to ensure specific antigen binding towards a target of multiple chemical structures. The optimization of the sensor design, the subsequent analytical performance and its real application are presented further.

\section{Materials and methods}

All procedures involving animals or humans were approved and conducted according to the Institutional Ethics Committee on research involving human (CEPSH of ICB/USP) (Protocol no. 1033/CEP) and the Committee for Animal Care and Utilization (CEUA of ICB/USP) (Protocol no. 116; book 02; page 119).

\subsection{Equipment}

The electrochemical measurements were conducted in a potentiostat/galvanostat from Metrohm Autolab/PGSTAT302N, impedimetic module and controlled by NOVA software. Au-SPEs were purchased from DROPSENS (DRP-C220AT), consisting of working and counter electrodes made of gold and the reference electrode and electrical contacts made of silver. The diameter of the working electrode was $4 \mathrm{~mm}$. The SWV measurement was conducted in $5.0 \mathrm{mmol} \mathrm{L}^{-1}$ of $\left[\mathrm{Fe}(\mathrm{CN})_{6}\right]^{3-}$ and $5.0 \mathrm{mmol} \mathrm{L}^{-1}$ of $\left[\mathrm{Fe}(\mathrm{CN})_{6}\right]^{4-}$, prepared in $\mathrm{PBS} \mathrm{pH}$ 7. In SWV potentials were changed from -0.7 to $+0.7 \mathrm{~V}$, corresponding to a frequency of 50 $\mathrm{Hz}$ and a step height of $150 \mathrm{mV}$. EIS assays were conducted with the same redox couple $\left[\mathrm{Fe}(\mathrm{CN})_{6}\right]^{3-/ 4-}$ at a standard potential of $0.12 \mathrm{~V}$, using a sinusoidal potential perturbation with an amplitude of $0.01 \mathrm{~V}$ (RMS) and the number of frequencies equal to 50 , logarithmically distributed over a frequency range of $0.1-$ $100 \mathrm{kHz}$. The impedance data were fitted to a Randles equivalent circuit using the implemented NOVA software.

\subsection{LDL isolation}

Blood samples were collected from healthy volunteers of both sexes, after fasting for 12 hours, with cholesterol and triglyceride concentrations in plasma within the normal range (cholesterol $<240 \mathrm{mg} \mathrm{dL}^{-1}$ and triglycerides $<160 \mathrm{mg} \mathrm{dL}^{-1}$, as confirmed by laboratorial data). Blood was collected in blood collection vacuum tubes (BD Vacutainer), containing $0.054 \mathrm{~mL}$ of anticoagulant, ethylenediaminetetraacetic acid (EDTA, disodium salt), $4.5 \mathrm{~mL}$ volume for suction. The blood of each volunteer was separately centrifuged $\left(1000 \times g, 4{ }^{\circ} \mathrm{C}\right.$, 10 minutes) and was used to create a pool of plasma. Then, a mixture of preservatives with $2 \mathrm{mM}$ benzamidine, $0.5 \%$ gentamycin, $\quad 0.25 \%$ chloramphenicol, $0.5 \mathrm{mM}$ phenylmethylsulfonylfluoride (PMSF) and 0.1 units per $\mathrm{mL}$ aprotinin was added to this pool.

LDL $\left(d=1006 \pm 1063 \mathrm{~g} \mathrm{~mL}^{-1}\right)$ was isolated by sequential ultracentrifugation at $100000 \mathrm{~g}$ for $20 \mathrm{~h}$ at $4{ }^{\circ} \mathrm{C},{ }^{32}$ using a $50 \mathrm{Ti}$ rotor, L-8 Ultracentrifuge, Beckman (VLDL: $12 \mathrm{~h}$, density = $1.006 \mathrm{~g} \mathrm{~mL}^{-1}$; LDL: $20 \mathrm{~h}$, density < $1.063 \mathrm{~g} \mathrm{~mL}^{-1}$; HDL: $40 \mathrm{~h}$, density $\left.<1.21 \mathrm{~g} \mathrm{~mL}^{-1}\right)$. LDL was dialyzed for $48 \mathrm{~h}$ in PBS-EDTA $0.01 \%$ pH $7.4\left(0.9 \% \mathrm{NaCl}, 0.3 \% \mathrm{Na}_{2} \mathrm{HPO}_{4}, 0.2 \% \mathrm{H}_{2} \mathrm{PO}_{4} ; \mathrm{NaOH}\right.$ $0.38 \%$ and $0.01 \%$ EDTA $)$ and filtered $(0.22 \mathrm{~mm}$ in diameter, Millipore). LDL preparations were stored at $4{ }^{\circ} \mathrm{C}$. The protein content was measured by Lowry's method. ${ }^{33}$

\subsection{LDL oxidation}

For the preparation of oxLDL, native LDL from 4 to $6 \mathrm{mg} \mathrm{mL}^{-1}$ was incubated with a solution of copper sulphate $\left(\mathrm{CuSO}_{4}\right)$, at a 
final concentration of $20 \mathrm{mM}$ for $18 \mathrm{~h}$ at $37^{\circ} \mathrm{C}$. The reaction was blocked with the addition of $1 \mathrm{mM}$ EDTA (Fernvik et al., 2004; Zaratin et al., 2002). To assess the extent of the LDL oxidation, the malondialdehyde (MDA) content was analyzed by measuring the thiobarbituric acid reactive substances (TBARSs). ${ }^{34,35}$ MDA was formed as a consequence of the peroxidation of LDL particles.

\subsection{Monoclonal antibodies (mAbs)}

The mAb-producing hybridomas anti-oxLDL, previously obtained inside the group, were tested against the product of oxLDL oxidation separated by molecular exclusion chromatography (superdex 200), by an ELISA indirect method and by competitive ELISA with synthetic peptides of apoB. ${ }^{36}$ The hybridomas were cultured in Dulbecco's Modified Eagle's Medium (DMEM) (Sigma-Aldrich) containing 10\% foetal calf serum (FCS), $100 \mu \mathrm{g} \mathrm{mL} \mathrm{m}^{-1}$-glutamine and $50 \mu \mathrm{g} \mathrm{mL}^{-1}$ gentamicin. The isotypes of the monoclonal antibodies (73, 77 and 87), present in supernatant fluid of hybridoma cultures, were stored at $-20{ }^{\circ} \mathrm{C}$ until purification.

The isotypes of the mAbs were determined by an ELISA indirect method, using the kit of Mouse Monoclonal Antibody Isotyping Reagents (SIGMA, Saint Louis, Missouri, USA). Briefly, the ELISA procedure was conducted with the anti-mouse IgG1, IgG2a, IgG2b, IgG3, IgM or IgA produced in goat, used at diluted $1: 1000$ to coat the wells of microtiter plates and left overnight at $4{ }^{\circ} \mathrm{C}$. Non-specific reactions were blocked with skim milk (5\% w/ v in PBS; Molico Milk, Nestle) for 2 hours at $37^{\circ} \mathrm{C}$. After that, the mAb73, 77 or 87 were added at a concentration of $250 \mu \mathrm{g} \mathrm{mL}$ and left for 1 hour at $37{ }^{\circ} \mathrm{C}$. Then, anti-mouse Ig horseradish peroxidase linked whole $\mathrm{Ab}$ (Amersham LIFE SCIENCE) diluted $1: 1000$ were added into every well and kept for 1 hour at $37^{\circ} \mathrm{C}$. This was followed by the addition of $o$-phenylenediamine dihydrochloride (OPD) (Sigma-Aldrich) with hydrogen peroxide as a substrate. Between all steps, the plate was washed four times with PBS-Tween containing 0.05\% Tween 20 (PBS-SM-T20) and three times with PBS. The reaction was stopped with sulphuric acid $2 \mathrm{~N}$ and read using a spectrophotometer at $492 \mathrm{~nm}$.

\subsection{Antibody purification}

The mAbs in the supernatant fluid were purified by affinity chromatography using Protein G (Protein G Sepharose 4 Fast Flow-Sigma-Aldrich). For this, $2 \mathrm{~mL}$ of Protein $\mathrm{G}$ were added to each $500 \mathrm{~mL}$ of hybridoma supernatant fluid, and the resulting mixture was subjected to mild agitation for $\sim 6$ hours, to allow the antibodies to bind to Protein G. After stirring, the flask was allowed to stand for the precipitation of Protein G. The supernatant was removed and Protein G was washed with PBS until the solution stayed clear. The non-adsorbed proteins were removed by washing with PBS. The mAbs were eluted from the column with $0.5 \mathrm{M}$ acetic acid, and collected in 10 drops of eluent flow, every 5 seconds, in tubes containing $250 \mu \mathrm{L}$ of Tris $1 \mathrm{M}$ of $\mathrm{pH} 8.8$, per well (to neutralize $\mathrm{pH}$ of the samples). The presence of proteins (antibodies) in each tube was detected by the Bradford method. After this, the aliquots were gathered to create a pool with a higher amount of protein, and subsequently dialyzed in PBS for $18 \mathrm{~h}$. The samples were stored at $4{ }^{\circ} \mathrm{C}$, protected from light. The as-purified mAbs were assayed for protein content by Lowry's method, ${ }^{33}$ separated in smaller vials, and stored at $-20{ }^{\circ} \mathrm{C}$ until use.

\subsection{Building of the immunosensor}

The immunosensor was setup by self-assembling Cyst (Cysteamine $\left.\left(\mathrm{C}_{9} \mathrm{H}_{13} \mathrm{~N}_{3} \mathrm{O}_{5}\right) 50 \mathrm{mM}\right)$ for 1 hour on the working $4 \mathrm{~mm} \phi$ gold $(\mathrm{Au})$ layer of a SPE. Antibodies were left to react with NHS ( $N$-hydroxysuccinimide $\left.\left(\mathrm{C}_{4} \mathrm{H}_{5} \mathrm{NO}_{3}\right) 25 \mathrm{mM}\right)$ and EDAC $(\mathrm{N}$-(3dimethylaminopropyl)- $N$ '-ethylcarbodiimide hydrochloride) for 15 minutes, and subsequently incubated in the Au/Cys. A drop of BSA $\left(0.5 \mathrm{mg} \mathrm{mL}^{-1}\right)$ was then added to the sensing layer, for 1 hour, to avoid non-specific binding. The modified electrodes were finally incubated with oxLDL in buffer solution for 15 minutes. All these steps of chemical modification were followed by EIS and SWV.

\subsection{Optimization of the immunosensor}

The kind and amount of mAbs were tested first. Biosensors were prepared with single mAb ( 73,77 or 87 ) or multiple mAbs $(73,77$ and 87 in the same device). The concentration of mAbs was always $50 \mu \mathrm{g} \mathrm{mL}^{-1}$ (in single mAb and in the pool of 3 different species of mAbs). Overall, the biosensor with a single mAb and three mAbs were produced with the same concentration of $\mathrm{Ab}$.

The obtained biosensors were calibrated by adding successive oxLDL standard solutions of increasing concentrations, and using the same conditions of electrical operation aforementioned for EIS and SWV studies.

The selectivity of the biosensor was assessed for native LDL, myoglobin equine skeletal muscle (Sigma-Aldrich) and haemoglobin human (Sigma-Aldrich), solutions prepared in PBS $\mathrm{pH} 7$, with high concentrations of $100 \mu \mathrm{g} \mathrm{mL} \mathrm{m}^{-1}$, for all negative controls. The time of contact given to these solutions was 1 hour.

To simulate the use of the immunosensor with patient's plasma with circulating oxLDL, the lowest concentration of oxLDL tested was diluted in FCS and the response was checked by EIS and SWV.

All electrochemical tests were carried out in triplicate.

\section{Results and discussion}

\subsection{Oxidation of native LDL}

To measure the extent of LDL oxidation, thiobarbituric acid measurements were employed. This compound is an important indicator of lipid peroxidation. Its concentration increased with the incubation time of LDL in copper sulphate, up to a maximum value where the oxidation no longer proceeded. The best time for oxidation was found at an $18 \mathrm{~h}$ incubation period.

The isolation and purification of the oxLDL in solution was made by ionic chromatography. As in any oxidation, carboxylic functions were introduced by oxidation and these carry an anionic charge under physiological $\mathrm{pH}$. So, the oxLDL fraction after an $18 \mathrm{~h}$ oxidation period was retained longer than the native LDL in an ion exchange column (Resource Q). 


\subsection{Antibody-antigen interactions}

All tests made regarding the mAbs showed that these were isotyped as IgG1. The mAb was tested against the product of oxLDL separated by molecular exclusion chromatography (superdex 200) by ELISA method. ${ }^{36}$ By competitive ELISA with synthetic peptides of apoB, only the mAb77 showed slightly decreased binding to oxLDL. Further information regarding these antibodies has been presented by Freitas, $2004 .^{36}$

The size distribution profile of oxLDL and the size of formation of the antigen (oxLDL)-antibody (mAb anti-oxLDL) complex was determined by dynamic light scattering. This was done simply by placing a drop of the solutions under study in Avid Nano DLS equipment.

The oxLDL solutions displayed nanostructures with an average size of $67.7 \mathrm{~nm} \phi$, with a standard deviation of $65.6 \mathrm{~nm}$. This unusually high standard deviation was expected, because the oxidized nanostructures were produced by random oxidation of the native LDL. ${ }^{37}$ The expected average molecular weight of oxLDL was $85013.13 \mathrm{kDa}$, corresponding to a polydispersion $\%$ of 0.94 .

The antigen-antibody ( $\mathrm{Ag}-\mathrm{Ab})$ complex had an average size of $208.9 \mathrm{~nm} \phi$, with a standard deviation of $130.1 \mathrm{~nm}$. Considering that each mAb may bind to two Ag species, and that the variation in the size of $\mathrm{Ag}$ was $65.6 \mathrm{~nm}$, a variation in $130.1 \mathrm{~nm}$ of the $\mathrm{Ag}-\mathrm{Ab}$ complex demonstrated the great ability of the $\mathrm{Ab}$ to bind to the target structures, independent of their size or exact structure. This was also expected because the mAbs had been targeted for this oxLDL mixture. The expected average molecular weight of oxLDL was $440162.20 \mathrm{kDa}$, corresponding to a polydispersion\% of 0.39 .

\subsection{Immunosensor design}

The immunosensor design consisted of creating an amine monolayer on a gold support to bind to the Ab through its Fc terminal. This would allow both paratope regions of the Ab to be free for subsequent antigen binding. The overall process can be seen in Fig. 1.

The amine monolayer was created by incubating the gold support on cysteamine: the thiol group bound to the gold and led to the formation of a compact amine monolayer (Fig. 1A). The presence of this layer on gold could be confirmed by the increase in the charge-transfer resistance $\left(R_{\mathrm{ct}}\right)$ observed after the gold clean support was incubated in cysteamine (Fig. 2). The $R_{\text {ct }}$ corresponded to the diameter of the semicircle, and its increase corresponded to an increased resistance in the electron

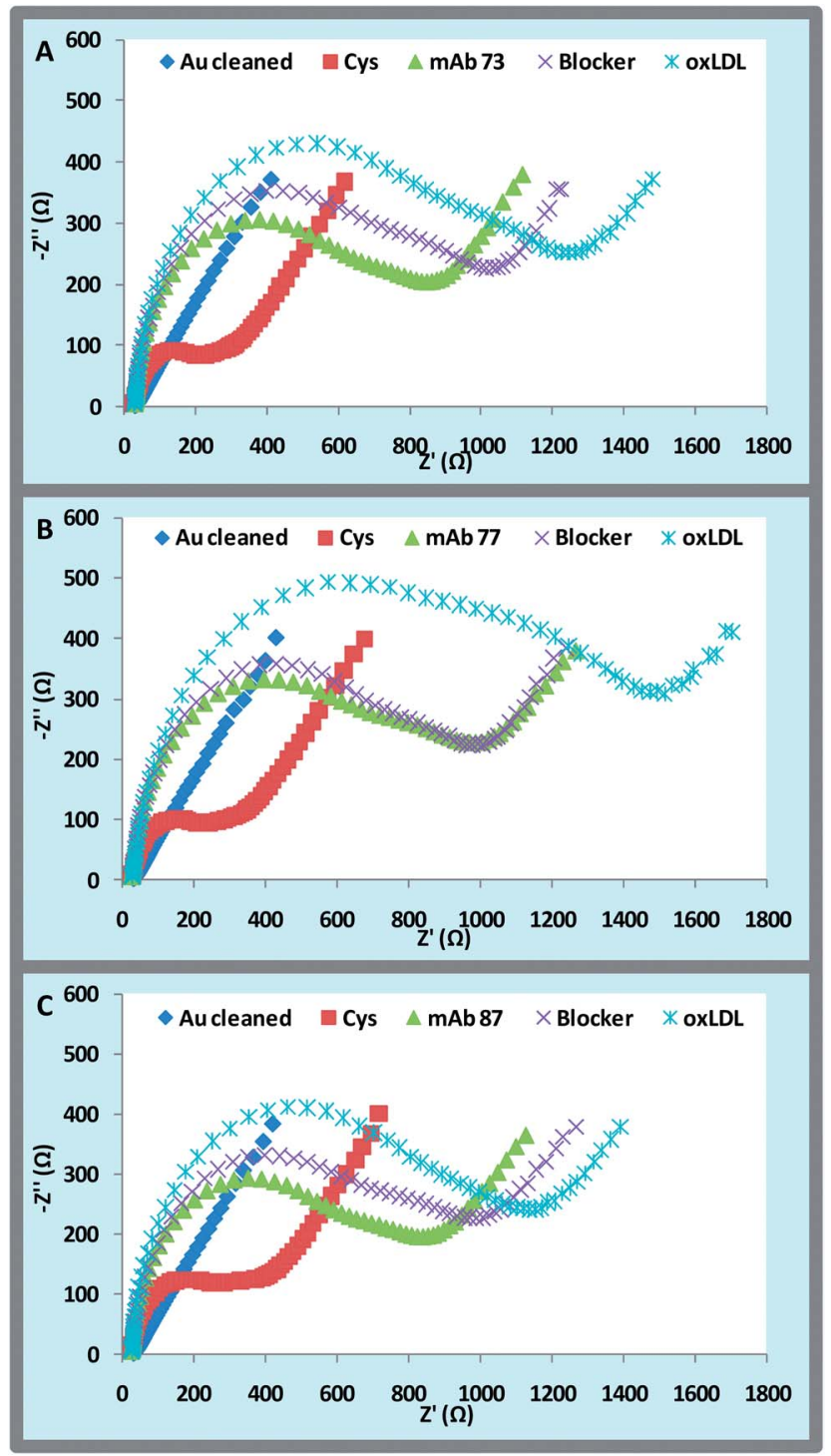

Fig. 2 The EIS response of the immunosensor assembly with single mAb (A) mAb73, (B) mAb77 and (C) mAb87.

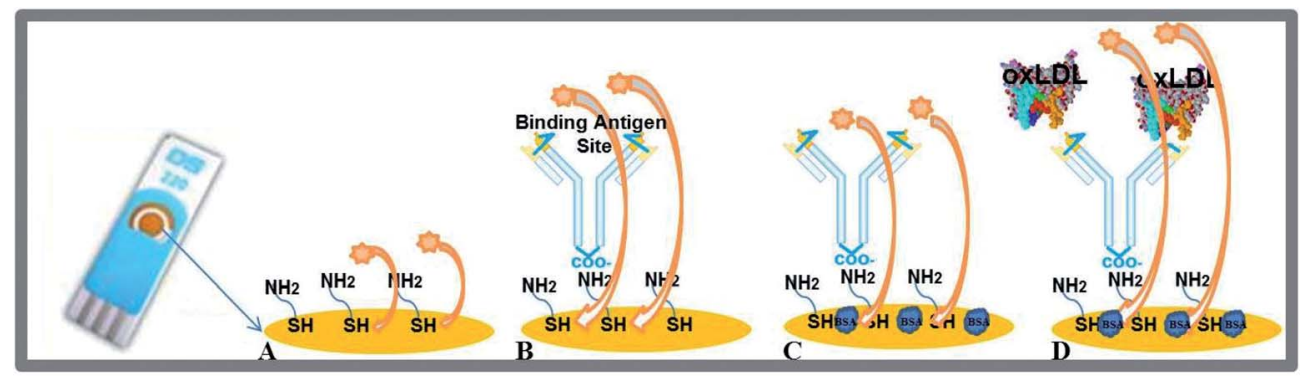

Fig. 1 Immunosensor assembly. A gold electrode with self-assembled cysteamine (A); antibody binding (B); BSA binding (C) and the modified electrodes were finally incubated with oxLDL (D). 
transfer kinetics of the iron redox-probe, accounting for the formation of a resistive layer.

In order to ensure an extensive $\mathrm{Ab}$ binding to the amine surface under mild conditions, the - $\mathrm{COOH}$ groups of the $\mathrm{Ab}$ had to be activated first by conventional EDAC-NHS chemistry. ${ }^{38}$ Once activated, the antibodies were connected to the support by covalent amide functional groups (Fig. 1B), promoting a significant increase in the $R_{\text {ct }}$ of the $\mathrm{Au} / \mathrm{NH}_{2}$ support (Fig. 2). This behaviour was consistent for all mAbs used.

All regions of the $\mathrm{Au} / \mathrm{NH}_{2} / \mathrm{mAb}$ support different from paratope sites could allow binding of other chemical species besides oxLDL. To avoid this, the biomaterial was incubated in BSA (Fig. 1C). Again, a significant increase in $R_{\mathrm{ct}}$ was observed (Fig. 2), thus confirming that BSA was bound to the Au/amine/ mAb surface and indicating that a great number of non-specific response sites had been blocked.

The Ag present in the immunosensor was expected to bind to the paratope sites of the Ab (Fig. 1D). As oxLDL particles were mainly negatively charged, the subsequent $R_{\mathrm{ct}}$ should decrease, considering that the iron redox probe used to check the charge transfer capability had the same charge. This was observed for all immunosensors (Fig. 2).

\subsection{Single and poly-monoclonal antibody response}

Different mAbs obtained from the same oxLDL mixture were called mAb73, mAb77 and mAb87. Each is expected to have different epitopes for the complex targeted mixture, meaning that immunosensors assembled with individual or combined mAb mixtures could have different electrical operation.

The immunosensor was first assembled in a single $\mathrm{Ab}$ arrangement, immobilizing only mAb73 or mAb77 or mAb87 on the Cys layer of the Au-SPE. Overall, each of these displayed similar EIS spectra, responding well to the oxLDL antigen diluted in buffer solution (Fig. 2). The EIS spectra of the assembly of the biosensor with multi-mAbs (the three kinds together in a single SPE) are shown in Fig. 3A. Its analytical performance (Fig. 3B) was similar to that displayed by the single mAb SPEs, which is in clear agreement with the simple fact that the area of the working layer to which the $\mathrm{Ab}$ may bind is the same, independent of the number or kind of Ab binding to it. The as-obtained device showed a linear response from 5 to $20 \mu \mathrm{g}$ $\mathrm{mL}^{-1}$, with slope and intercept values of $41.33\left(\Omega \times \mathrm{mL}_{\mu \mathrm{g}}^{-1}\right)$ and $1267.4 \Omega$, respectively. Each device was produced in triplicate and the results obtained showed good reproducibility, always below $5 \%$.

Overall, the single or multi-immunosensing devices displayed similar features. Still, only multi-mAb was used in further studies, because it was reasonable to assume that different epitopes for the same target mixture comprising multiple oxidised nanostructures of LDL would favour the specificity of the analytical response.

\subsection{Selectivity study}

To check the ability of the mAb to discriminate oxLDL nanostructures from the parent or coexisting compounds in serum, the response of the multi-mAb biosensor was checked against

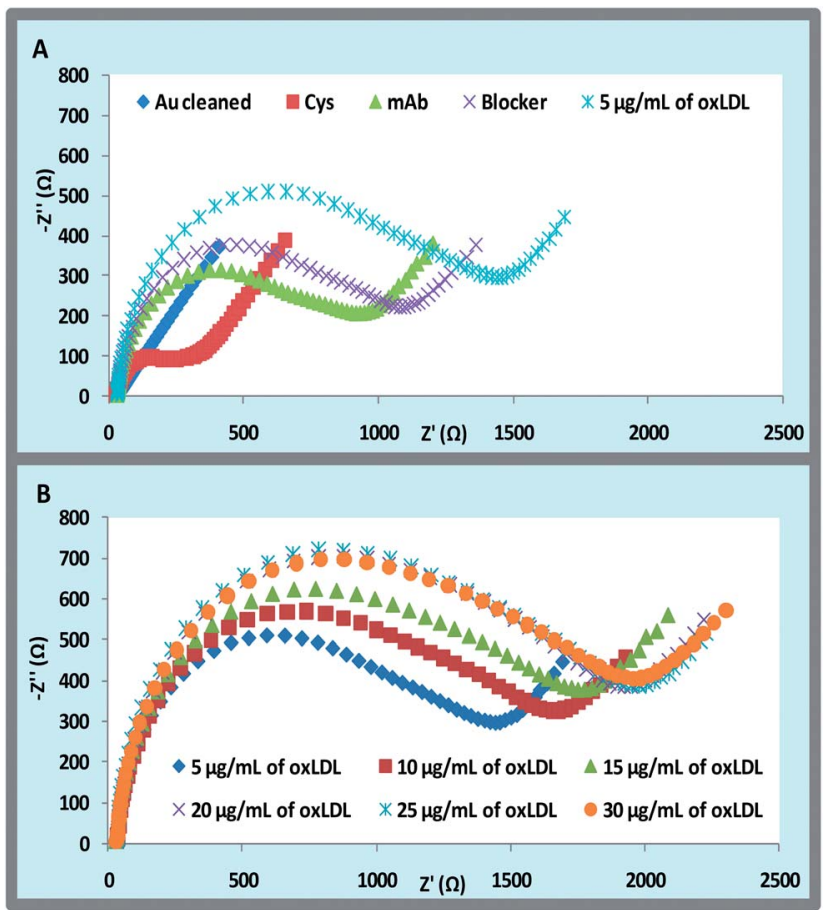

Fig. 3 EIS spectra obtained on the assembly of the multi-mAb immunosensor ((A) including a cleaned Au surface, Cys, mAb73, 77 and 87 together $(m A b)$, block with BSA and the response to the first standard of oxLDL, $5 \mu \mathrm{g} \mathrm{mL} \mathrm{m}^{-1}$ ) and its subsequent calibration with oxLDL ranging from 5 to $30 \mu \mathrm{g} \mathrm{mL}^{-1}$ (B).

native LDL, myoglobin and haemoglobin. This was done by placing a drop of the corresponding solutions on the platform that had been blocked by BSA. This study was made with foreign solutions having a high concentration of the target species, $100 \mu \mathrm{g} \mathrm{mL}{ }^{-1}$, and the time given for affinity reaction with the platform was 1 hour. This procedure was the same for the negative control made with buffer. Repeated applications of solutions with foreign species were made, ensuring that the effects of their abnormally high levels in serum would also be checked.

In general, the immunosensor incubated in foreign species showed the same response as that shown by the immunosensor after BSA incubation (Fig. 4), confirming that they were unable to react with the mAbs placed in the outer surface of the biosensor. None of the previous foreign species at any of the concentrations tested were able to change the baseline response of the immunosensor. Even native LDL was unable to change the response of the device, thus confirming the specificity of the dimensional platform towards the targeted oxLDL material. The biosensor did not respond to other antigens at 15 minutes and even for contact times up to $1 \mathrm{~h}$.

Overall, the biosensor demonstrated excellent results in terms of sensitivity and specificity. Tests with nonspecific antigens as native LDL, myoglobin and hemoglobin, made with FCS without human oxLDL, also grant avoiding or masking the response of the device with monoclonal antibodies. The results showed the feasibility of the immunosensor to be applied to patients with an over concentration of side-antigens. 

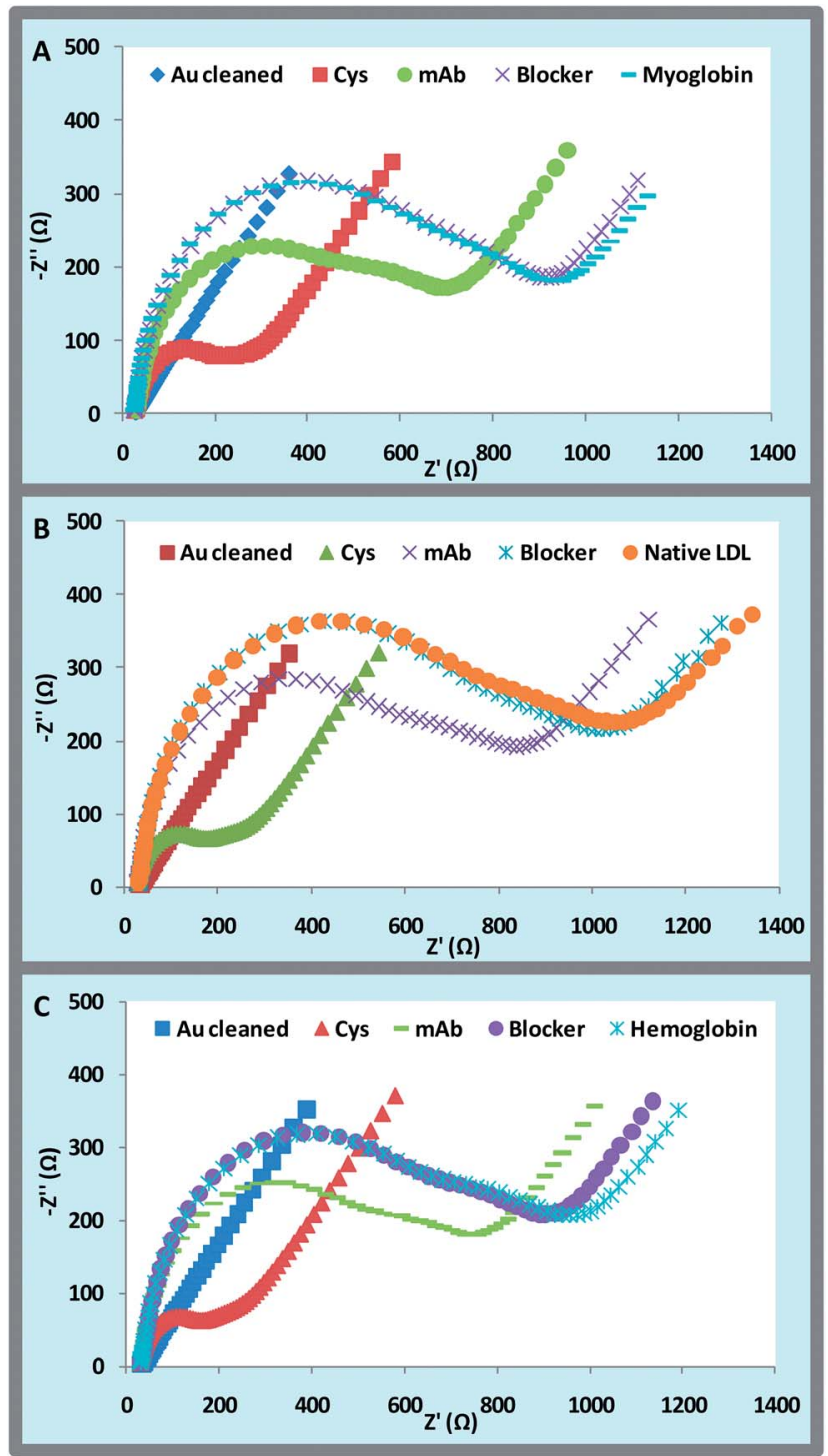

Fig. 4 Selectivity test against proteins in serum that coexist with oxLDL. (A) myoglobin, (B) native LDL and (C) haemoglobin.

\subsection{Analytical performance}

The immunosensor with multi-mAbs was assembled next to check its response against oxLDL, for concentrations up to $50 \mu \mathrm{g} \mathrm{mL} \mathrm{m}^{-1}$. The overall response showed that the biosensor responded well after $5 \mu \mathrm{g} \mathrm{mL} \mathrm{m}^{-1}$ oxLDL, this being the concentration level included in the linear response range of the device. The linear response was observed up to $20 \mu \mathrm{g} \mathrm{mL}^{-1}$, being expressed as $R_{\mathrm{ct}}(\Omega)=41.33 \times$ oxLDL $\left(\mu \mathrm{g} \mathrm{mL} \mathrm{m}^{-1}\right)+1267.4$, with a squared correlation coefficient of 0.994 . The standard deviation of replicate measurements was below $5 \%$.

\subsection{Serum reading and practical application of the device}

Considering that the targeted biosensor was meant to operate well in serum, it was important to check the performance of the biosensor under close-to-real conditions. This was done by replacing the buffer solution by FCS, prepared in diluted or non- diluted (equal to biological composition) solutions. FCS was used to simulate serum because it displays great similarity to human's serum..$^{39}$ SWV and EIS studies were conducted for this intended application.

The EIS spectra of the immunosensor tested with oxLDL diluted in FCS showed clear evidence of the presence of the affinity between oxLDL and the mAbs (Fig. 5A). To ensure that FCS was not responsible for this $R_{\mathrm{ct}}$ increase, a blank signal was measured for FCS without oxLDL (Fig. 5B). This negative control showed that all biological species present in FCS were unable to interact with the immunosensor surface. This attributed the device a specific response to human oxLDL, which is mostly related to the specific affinity between the mAbs and oxLDL, combined with the immunosensor design.

The analytical performance of the immunosensor in FCS solutions was checked by calibrating the device with oxLDL standards prepared in FCS. Since all samples would need at least one dilution step prior to analysis, diluted FCS was used in this case. The oxLDL concentration range was set to $0.50-50 \mu \mathrm{g}$ $\mathrm{mL}^{-1}$. Under these conditions, the immunosensor was able to detect human oxLDL from 0.50 to $18.0 \mu \mathrm{g} \mathrm{mL} \mathrm{m}^{-1}$. The slope and

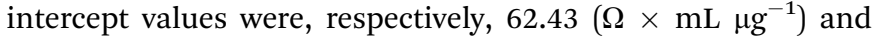
$540.2 \Omega$, with a squared correlation coefficient of 0.9951 (typical spectra in Fig. 6A and B). The limit of detection was $0.22 \mu \mathrm{g} \mathrm{mL}{ }^{-1}$, calculated as the interception between the linear and non-liner parts of the calibration curve.

The performance of the immunosensor in diluted FCS was also checked by SWV. The voltammograms so obtained can be seen in Fig. 6. In general, the assembly of the device decreased

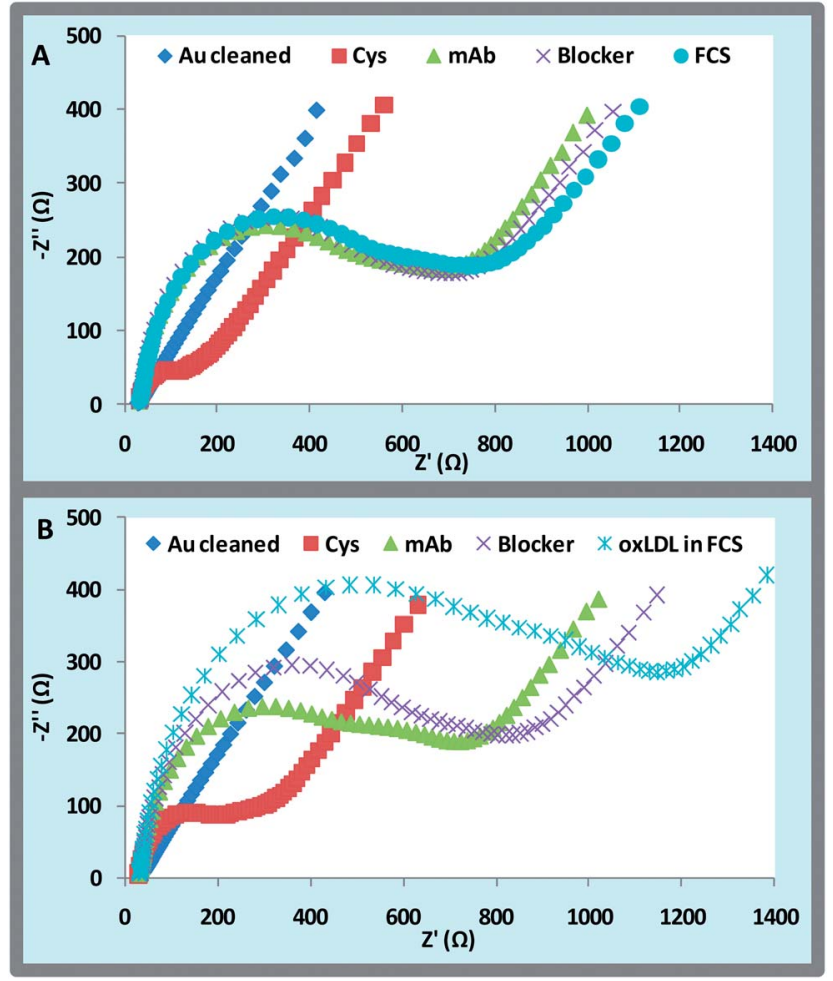

Fig. 5 EIS spectra of the immunosensor with FCS (A) or oxLDL diluted in FCS (B). 

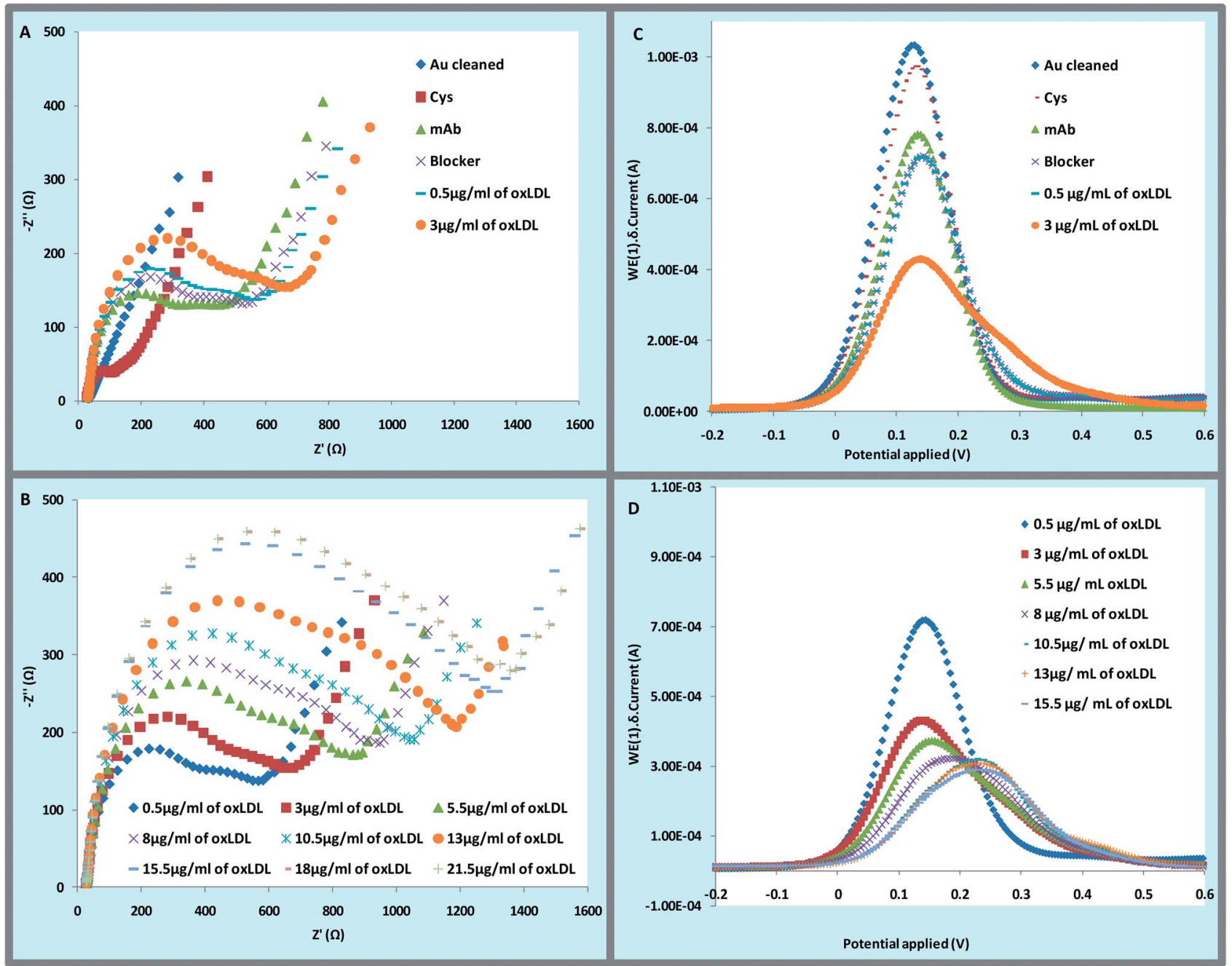

Fig. 6 EIS spectra of the immunosensor assembly and oxLDL response (A) and its operation when diluted in FCS, calibrated with oxLDL ranging from 0.5 to $21.5 \mu \mathrm{g} \mathrm{mL}^{-1}$, and the corresponding SWV data ( $C$ and $D$, respectively).

the peak current of the redox probe (Fig. 6C), which was consistent with the previous EIS data. The calibration in SWV showed linear responses ranging from 3.0 to $10.5 \mu \mathrm{g} \mathrm{mL}$ (Fig. 6D), pointing to that EIS seemed to be a more suitable technique for analytical application.

\section{Conclusions}

The use of monoclonal antibodies on a biosensing platform was an effective approach to monitor the level of oxLDL fraction in the blood, a parameter of major relevance in atherosclerosis disease. EIS was a suitable technique to follow the affinity reaction between the mAbs immobilized on the screen-printed electrode and oxLDL. The immunosensor displayed an unusual specificity for the targeted analyte, being able to detect it when present in real serum matrices, at concentrations within physiological levels.

Reading in real time is achieved within 20 minutes, including binding of the antibody to the antigen and EIS reading, and avoiding unnecessary use of conjugated antibodies for detection purposes. The screen-printed electrode device proposed here is expected to cost less than $€ 10$, excluding here the price associated with the first production of the mAbs, because the necessary hybridoma cells have already been established and these cells are able to produce antibodies "indefinitely".

The immobilization of the antibody on the screen-printed electrode is also a quick process, taking only a few hours, unlike the typical overnight incubation in the diagnostics standards. In addition, the Ab immobilization in ELISA does not guarantee the Fab region free to bind the antigen. So, to have a good grip of the antibody in an ELISA plate, it is necessary that the board is of the type "high binding plates", but these boards are quite expensive and even so the correct antibody orientation is not guaranteed.

In brief, compared to the gold standard protocol of ELISA, the proposed device provides a much faster response at a much lower cost, also aiming at a suitably oriented antibody binding. Overall, the produced device is simple, fast, cheap, and portable, showing great potential to improve the current diagnosis of atherosclerosis in point-of-care testing. 


\section{Acknowledgements}

The authors acknowledge CAPES (Coordenação de Aperfeiçoamento de Pessoal de Nível Superior, Brasil) and CNPq (Conselho Nacional de Desenvolvimento Científico e Tecnológico, Brasil, programa Ciência sem Fronteira) for the financial support (GCM). ScanSci spectroscopic solutions is acknowledged for use of the Avid Nano equipment, advancing Dynamic Light Scattering measurements.

\section{References}

1 Medline Plus, from the US National Library of Medicine, National Institutes of Health, Coronary heart disease, http:// www.nlm.nih.gov/medlineplus/ency/article/007115.htm, accessed in 28th July 2013.

2 J. Frostegard, J. Intern. Med., 2005, 257, 485-495.

3 P. Lybby, P. M. Ridker and G. K. Hansson, Nature, 2011, 473, 317-325.

4 S. Balanescu, L. Calmac, D. Constantinescu, M. Marinescu, R. Onut and M. Dorobantu, J. Clin. Med., 2010, 5, 292-302.

5 H. Vlassara, H. Fuh, T. Donnelly and M. Cybulskyt, Mol. Med., 1995, 1, 447-456.

6 F. R. Maxfield and I. Tabas, Nature, 2005, 438, 612-621.

7 S. Ehara, M. Ueda, T. Naruko, K. Haze, A. Itoh, M. Otsuka, R. Komatsu, T. Matsuo, H. Itabe, H. Takano, Y. Tsukamoto, M. Yoshiyama, K. Takeuchi, J. Yoshikawa and A. E. Becker, Circulation, 2001, 103, 1955-1960.

8 J. Frostegard, BMC Med., 2013, 11, 117-130.

9 J. Frostegard, J. Nilsson, A. Haegerstrand, A. Hamsten, H. Wigzell and M. Gidlund, Proc. Natl. Acad. Sci. U. S. A., 1990, 87, 904-908.

10 R. Stocker and J. F. Keaney Jr, Physiol. Rev., 2003, 84, 13811478.

11 H. Itabe and M. Ueda, J. Atheroscler. Thromb., 2007, 14, 1-11.

12 T. Sakurai, N. Wada, Y. Takahashi, A. Ichikawa, A. Ikuta, H. Furumaki, S. P. Hui, S. Jin, S. Takeda, H. Fuda, M. Fujikawa, C. Shimizu, H. Nagasaka, H. Furukawa, S. Kobayashi and H. Chiba, Ann. Clin. Biochem., 2013, 3, 1-8.

$13 \mathrm{H}$. Hinterwirth, G. Stübiger, W. Lindner and M. Lämmerhofer, Anal. Chem., 2013, 85, 8376-8384.

14 G. Siegel, M. Rodríguez, F. Sauer, C. Abletshauser, C. Mey, K. Schötz, L. Ringstad, M. Malmsten and P. Schäfer, Biosens. Bioelectron., 2009, 24, 1512-1517.

15 G. Siegel, M. Malmsten, D. Klüßendorf and F. Michel, Biosens. Bioelectron., 2001, 16, 895-904.

16 M. M. Stollenwerk, O. Svensson, A. Schiopu, B. Jansson, T. Arnebrant and G. N. Fredrikson, Biochim. Biophys. Acta, 2011, 1810, 211-217.

17 T. E. S. Faulin, K. C. M. Sena, A. E. R. T. Telles, D. M. Grosso, E. S. B. Faulin and D. S. P. Abdalla, Clin. Chem. Lab. Med., 2008, 46, 1769-1775.

18 H. Itabe and M. Ueda, J. Atheroscler. Thromb., 2007, 14, 1-11.
19 B. D. Malhotra, A. Chaubey and S. P. Singh, Anal. Chim. Acta, 2006, 578, 59-74.

20 L. Murphy, Biosensors and bioelectrochemistry, Curr. Opin. Chem. Biol., 2006, 10, 177-184.

21 S. Takeda, S. P. Hui, K. Fukuda, H. Fuda, S. Jin, T. Sakurai, A. Ishii, K. Mukasa, K. Sueoka and H. Chiba, Sens. Actuators, B, 2012, 166, 833-836.

22 Y. R. Yuan, R. Yuan, Y. Q. Chai, Y. Zhuo and X. M. Miao, J. Electroanal. Chem., 2009, 626, 6-13.

23 H. Zhao and H. Ju, Anal. Biochem., 2006, 350, 138-144.

24 X. Chu, Z. L. Zhao, G. L. Shen and R. Q. Yu, Sens. Actuators, B, 2006, 114, 696-704.

25 R. Hao, D. Wang, X. Zhang, G. Zuo, H. Wei, R. Yang, Z. Zhang, Z. Cheng, Y. Guo, Z. Cui and Y. Zhou, Biosens. Bioelectron., 2009, 24, 1330-1335.

26 H. Zhang, G. Grüner and Y. Zhao, J. Mater. Chem. B, 2013, 1, 2542-2567.

27 W. C. Tsai and I. C. Lin, Sens. Actuators, B, 2005, 106, 455460.

28 G. Liu, H. Chen, H. Peng, S. Song, J. Gao, J. Lu, M. Ding, L. Li, S. Ren, Z. Zou and C. Fan, Biosens. Bioelectron., 2011, 28, 308313.

29 R. J. Chen, S. Bangsaruntip, K. A. Drouvalakis, N. W. S. Kam, M. Shim, Y. Li, W. Kim, P. J. Utz and H. Dai, Proc. Natl. Acad. Sci. U. S. A., 2003, 100, 4984-4989.

30 N. S. Lipman, L. R. Jackson, L. J. Trudel and F. Weis-Garcia, ILAR J., 2005, 46, 258-268.

31 D. Saerens, L. Huang, K. Bonroy and S. Muyldermans, Sensors, 2008, 8, 4669-4686.

32 R. J. Havel, H. A. Eeder and J. H. Gragdon, J. Clin. Invest., 1955, 34, 345-353.

33 O. H. Lowry, N. J. Rosebrough, A. L. Farr and R. J. Randall, J. Biol. Chem., 1951, 193, 265-275.

34 E. C. Fernvik, D. F. Ketelhuth, M. Russo and M. Gidlund, J. Clin. Immunol., 2004, 24, 170-176.

35 A. Zaratin, M. Gidlund, P. Boschcov, L. Castilho and E. C. Faria, Am. J. Cardiol., 2002, 90, 651-653.

36 F. C. Silva e Freitas, Geração de anticorpos monoclonais antiLDL modificad, visando o desenvolvimento de métodos de detecção, identificação, quantificação e isolamento de produtos de modificação de lipoproteínas de baixa densidade (LDL) e análise da captação de LDL modificado, Master thesis, in Instituto de Ciências Biomédicas da Universidade de São Paulo, under the supervision of Magnus Ake Gidlund, Universidade de São Paulo, 2004.

37 N. R. Damasceno, A. Sevanian, E. Apolinario, J. M. Oliveira, I. Fernandes and D. S. P. Abdalla, Clin. Biochem., 2006, 39, 28-38.

38 K. Y. Jiang, L. S. Schadler, R. W. Siegel, X. J. Zhang, H. F. Zhang and M. Terrones, J. Mater. Chem., 2004, 14, 37-39.

39 T. Lindl, Zell-und Gewebekultur, 5th edn, Spektrum akademischer Verlag, Heidelberg, 2002. 
APÊNDICE B - 2ํㅡㄹ Artigo: Backside-surface imprinting as a new strategy to generate specific plastic antibody materials 
Cite this: J. Mater. Chem. B, 2014, 2, 3087

Received 7th December 2013 Accepted 25th February 2014

DOI: $10.1039 / c 3 t b 21740 j$

www.rsc.org/MaterialsB

\section{Backside-surface imprinting as a new strategy to generate specific plastic antibody materials}

\author{
Gustavo Cabral-Miranda, ${ }^{\text {ab }}$ Magnus Gidlund ${ }^{\mathrm{b}}$ and M. Goreti F. Sales ${ }^{\star a}$
}

\section{Introduction}

An antibody (Ab) or immunoglobulin (Ig) is a protein molecule of the immune system that binds with a high degree of affinity and specificity to a specific target species called antigen. ${ }^{1}$ This feature justifies its intensive use as a reagent in diagnostic assays and therapeutics, with a great impact on the improvement of health and welfare in both humans and animals. ${ }^{2,3}$ This is possible due to well-established experimental protocols leading to their production on a high scale, but their inherent complexity and $\operatorname{cost}^{4}$ has guided researchers towards finding new synthetic pathways for $\mathrm{Ab}$ designing.

The most successful synthesis route for obtaining antibodies makes use of molecular imprinting technology, ${ }^{5}$ first discovered in 1931 by Polyakov, ${ }^{6}$ and demonstrated later in 1972 by Wulff and Sarhan. ${ }^{7,8}$ The enthusiasm of researchers within this field of biomimetic materials started then and lasts until today. ${ }^{9}$ In brief, an imprinted polymer is produced by growing a rigid

${ }^{a}$ BioMark/ISEP, School of Engineering, Polytechnic Institute of Porto, António Bernardino de Almeida, 431, 4200-072 Porto, Portugal.E-mail: goreti.sales@gmail. com; Fax: +351 228321 159; Tel: +351 228340544

${ }^{b}$ Laboratory of Immunophysiopathology, Department of Immunology at the Institute of Biomedical Sciences IV (ICB-IV), University of Sao Paulo (USP), Brazil polymeric network around a target molecule. The imprinted sites are generated once the template exits the polymer matrix, theoretically matching the size and shape of the target. Despite many years of progress, targeting big-sized molecules such as proteins by molecular imprinting technology is still a challenge. ${ }^{10-12}$ Size, complexity, conformational flexibility and solubility of proteins are main obstacles, which have been surpassed by using bulk, epitopes or surface imprinting approaches. ${ }^{10-23}$

Surface imprinting seems by far the most successful approach in plastic $\mathrm{Ab}$ design. It consists mostly in attaching the template to the surface, enabling a pre-polymerization stage where functional monomers are allowed to bind to the template molecule, and polymerize the monomeric material by controlled/living free radical polymerization..$^{17,22,23}$ In general, the covalent immobilization of the template molecules at the surface of solid substrates offers some advantages: it enables imprinting templates that are insoluble in the pre-polymerization mixture and minimizes template aggregation, thus leading to more homogeneous binding sites. ${ }^{17}$

But the materials produced by surface imprinting contain areas that are able to interact with foreign-proteins by means of non-specific interactions, which in turn reduce the selectivity of the material for its target compound. Promoting a chemical 
differentiation between the binding site and the surrounding surface was recently proposed to reduce this effect. This was made by adding charged positions to the binding sites and polymerizing the surrounding area with neutral monomers. ${ }^{24}$ The obtained biomimetic materials were named Smart Plastic Antibody Materials (SPAMs), showing enhanced affinity and selectivity for the targeted protein.

However, SPAMs shared a common difficulty in surface imprinting which is the control of the thickness of the polymer layer. When the polymer thickness is higher than the template size, measured when attached to the receptor surface, the template to be imprinted is unable to come out of the polymeric network. Controlling the polymer thickness in surface imprinting is therefore fundamental because the number of binding sites and the dimensions of these sites are directly correlated with this simple feature. It is however a difficult task because the protein templates are usually smaller than $10 \mathrm{~nm}$ and the template may be attached to the receptor surface in different positions, which according to the protein conformation above the surface may lead to different polymer thickness requirements within the same material.

To overcome the dependency of the polymer thickness, this work reports a backside imprinted layer of the SPAM plastic antibody, this time named MAPS (Materials Antibody Plastic Smart), the backside reading of SPAM. The cross-section of the imprinted material where the protein displays a higher density is the $z$-axis plane corresponding to the protein covalent bond. If this layer is able to come out, all proteins would be at the same distance for exiting the material. Overall, this new approach is expected to ensure that all proteins are in contact with the outer surface and able to exit the imprinted matrix, thus generating surfaces with a high density of rebinding sites.

Herein, this new concept is applied to target oxidized LowDensity Lipoprotein (oxLDL) fractions, composed of different particles of oxidized LDL. Increased plasma levels of oxLDL are associated with atherosclerosis which promotes vascular dysfunction by exerting direct cytotoxicity on endothelial cells and increases chemotactic properties for monocytes and macrophages and consequent transformation into foam cells, which contributes to atherogenesis. The oxLDL level in circulating plasma is commonly recognized as an important predictive marker of risk to a cardiovascular event, therefore, novel approaches with simple procedures and low cost are highly urgent and would be greatly appreciated.

In brief, oxLDL was covalently bond to a supporting film of carboxylated-PVC cast on a gold support of a screen-printed electrode (SPE), no. 1, let to interact with charged monomers and covered by a neutral polymeric network. The outer surface of this polymer was then covalently attached to another transducing element that was another SPE (no. 2), binding the two SPEs together. These two SPEs were separated after stripping out SPE-1, which extracted the carboxylated-PVC film along with the oxLDL. The backside of the chemical structure set-up in SPE-1 was now exposed as the top-side of SPE-2. Extensive template extraction was further ensured by an enzymatic reaction. Non-imprinted materials (NIMs) were also produced as blank and were used as the control for the imprinting process.
All chemical modifications of the supporting film and the transducing element were followed by electrochemical techniques, both in MAPS and NIM materials. The resulting devices were also evaluated by electrochemical techniques and further tested in a Fetal-Calf Serum (FCS) background, nearing its application to real biological samples.

\section{Experimental section}

\subsection{Apparatus}

Electrochemical measurements were conducted in a potentiostat/galvanostat from Metrohm Autolab/PGSTAT302N with an impedimetric module of the same brand. It was controlled by NOVA software. SPEs used were purchased from Drop Sense (DRP-C220AT), having working and counter electrodes made of gold and reference electrode and electrical contacts made of silver. The diameter of the working electrode was $4 \mathrm{~mm}$.

Surface analysis was carried out by using a Scanning Electron Microscope (SEM) of JEOL, JSM-6010LA InTouchScope in vacuum mode. Morphological analysis was conducted using a Scanning Electron Microscope (SEM), JSM-6010LA in vacuum mode. An ultracentrifuge from Beckman, 50Ti rotor, L-8, was used in the preparation of serum samples.

\subsection{Reagents}

All chemicals were of analytical grade and de-ionized water (conductivity $<0.1 \mu \mathrm{S} \mathrm{cm}^{-1}$ ) was used. Poly(vinyl chloride) carboxylated (PVC-COOH, Fluka), 2-nitrophenyl octylether (ONPOE, Fluka), tetrahydrofuran (THF, Aldrich), $N$-hydroxysuccinimide (NHS, Fluka), $N$-(3-dimethylaminopropyl)- $N^{\prime}$ ethylcarbodiimide hydrochloride (EDAC, Sigma), ethylenediamine (EA, Merck), vinyl benzoate (VB, Aldrich), (vinylbenzyl) trimethylammonium chloride ( $\mathrm{VB}+$, Acros Organics), benzoyl peroxide (BPO, Himedia), methacrylic acid (MAA, Aldrich), ethylene glycol dimethacrylate (EGDMA, TCI), 3-mercaptopropionic acid (MPA, Sigma), proteinase $\mathrm{K}$ from tritirachium album (Sigma), ethyelenodiamine tetraacetic acid (EDTA, disodium salt), copper sulphate $\left(\mathrm{CuSO}_{4}\right)$, myoglobin equine skeletal muscle (Myo, Sigma-Aldrich) and human haemoglobin $(\mathrm{Hb}$, Sigma-Aldrich) were used.

Native LDL was obtained from patients as described later and dialysed prior to its oxidation. oxLDL was obtained by copper based oxidation of LDL and was further analyzed with regard to its MDA content, by measuring thiobarbituric acid reactive substances (TBARS). ${ }^{25,26}$

\subsection{Solutions}

The buffer used throughout this work was PBS, $\mathrm{pH} 7.2$, and was prepared by mixing $0.9 \% \mathrm{NaCl}, 0.3 \% \mathrm{Na}_{2} \mathrm{HPO}_{4}, 0.2 \% \mathrm{H}_{2} \mathrm{PO}_{4}$ and $0.38 \%(\mathrm{w} / \mathrm{v}) \mathrm{NaOH}$. For the oxidation of LDL, native LDL from 4 to $6 \mathrm{mg} \mathrm{mL}^{-1}$ prepared in buffer, $20 \mathrm{mmol} \mathrm{L}^{-1} \mathrm{CuSO}_{4}$ solution in water, and $1 \mathrm{mmol} \mathrm{L}^{-1}$ EDTA in buffer were used.

For the synthesis of MAPS $0.1 \mathrm{~g}$ of PVC-COOH and $0.12 \mathrm{~g}$ of ONPOE dissolved in $\sim 1.5 \mathrm{~mL}$ THF were used. For the activation of carboxylic functions $25 \mathrm{mmol} \mathrm{L}^{-1} \mathrm{NHS}$ and $50 \mathrm{mmol} \mathrm{L}^{-1}$ EDAC, both prepared in water, were used. The $4 \mathrm{mg} \mathrm{ml}^{-1}$ oxLDL 
solution used to assemble MAPS was prepared in water. EA solutions were prepared in ionized water with a $0.5 \mathrm{~mol} \mathrm{~L}^{-1}$ concentration. The monomer solutions were prepared in water, having $5.0 \times 10^{-3} \mathrm{~mol} \mathrm{~L}^{-1}\left(\mathrm{VB}, \mathrm{MAA}\right.$ or EGDMA) or $1.0 \times 10^{-2}$ mol $\mathrm{L}^{-1}(\mathrm{VB}+)$ concentrations. The radical initiator BPO was $5.0 \times 10^{-4} \mathrm{~mol} \mathrm{~L}^{-1}$, freshly prepared in water. MPA solution was $1 \times 10^{-3} \mathrm{~mol} \mathrm{~L}^{-1}$ prepared in ionized water. Proteinase $\mathrm{K}$ solutions were $500 \mu \mathrm{g} \mathrm{mL} \mathrm{m}^{-1}$ prepared by suitable dilution of the commercial reagent in buffer. Stock solutions of oxLDL had a $4 \mathrm{mg} \mathrm{ml} \mathrm{m}^{-1}$ concentration and were prepared in buffer. Less concentrated standards were prepared by accurate dilution of the previous solution in the same buffer. The selectivity study required the preparation of oxLDL, Myo, $\mathrm{Hb}$ and native $\mathrm{LDL}$, all with concentrations of $50 \mu \mathrm{g} \mathrm{mL} \mathrm{m}^{-1}$ and prepared in buffer. EIS assays used a solution containing $5.0 \mathrm{mmol} \mathrm{L}^{-1}$ of $\left[\mathrm{Fe}(\mathrm{CN})_{6}\right]^{3-}$ and $5.0 \mathrm{mmol} \mathrm{L}{ }^{-1}$ of $\left[\mathrm{Fe}(\mathrm{CN})_{6}\right]^{4-}$, prepared in buffer.

\subsection{Isolation of native LDL}

Blood samples were collected from healthy volunteers, of both sexes, after fasting for 12 hours, with cholesterol and triglyceride plasma concentrations ranging within the normal levels

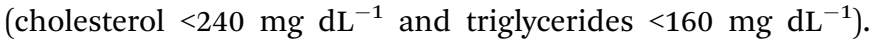
These procedures were conducted according to the Ethics Committee on research involving humans of the Institute of Biomedical Sciences, University of São Paulo, Brazil, and approved in protocol no. 1033/CEP.

Blood was collected in vacuum tubes (BD Vacutainer), containing $0.054 \mathrm{~mL}$ of anticoagulant EDTA, $4.5 \mathrm{~mL}$ volume for suction. The blood of each volunteer was centrifuged $(1000 \times g$, $4{ }^{\circ} \mathrm{C}, 10$ minutes) separately and later used to create a pool of plasmas. This pool was added with preservatives $\left(2 \mathrm{mmol} \mathrm{L}^{-1}\right.$ benzamidine, $0.5 \%$ gentamycin, $0.25 \%$ chloramphenicol, $0.5 \mathrm{mmol} \mathrm{L}^{-1}$ phenylmethylsulfonylfluoride and 0.1 units per $\mathrm{mL}$ aprotinin), prior to freezing.

LDL (density of $1006 \pm 1063 \mathrm{~g} \mathrm{~mL}^{-1}$ ) was isolated by sequential ultracentrifugation at $100000 \times g$ for $20 \mathrm{~h}$ at $4{ }^{\circ} \mathrm{C}^{27}$ using (VLDL: $12 \mathrm{~h}, 1.006 \mathrm{~g} \mathrm{~mL}^{-1}$; LDL: $20 \mathrm{~h},<1.063 \mathrm{~g} \mathrm{~mL}^{-1}$; HDL: $40 \mathrm{~h},<1.21 \mathrm{~g} \mathrm{~mL}^{-1}$ ). LDL was dialyzed for $48 \mathrm{~h}$ in PBS buffer with $0.01 \%$ EDTA and filtered (0.22 micron in diameter, Millipore). LDL preparations were stored at $4{ }^{\circ} \mathrm{C}$. The protein content was measured by the Lowry's method. ${ }^{28}$

\subsection{Synthesis of oxLDL and its characterization}

The oxidation of LDL was carried out as described earlier, ${ }^{26,29}$ using native LDL from 4 to $6 \mathrm{mg} \mathrm{mL}^{-1}$. The LDL solution was then incubated in a solution of $20 \mathrm{mmol} \mathrm{L}^{-1} \mathrm{CuSO}_{4}$ at $37^{\circ} \mathrm{C}$. The time of incubation was set to $18 \mathrm{~h}$, as the TBA content (an important indicator of lipid peroxidation) increased up to a maximum and reached a steady value after this period of time. In addition, native LDL and oxLDL retention on ion exchange columns (Resource Q) in the fast protein liquid chromatography (FPLC) have shown increased retention of oxLDL relative to native LDL within this time of oxidation, correlated with an increased number of negatively charged particles. The oxidation of LDL was blocked with the addition of $1 \mathrm{mmol} \mathrm{L}^{-1}$ EDTA.
The oxLDL solutions displayed nanostructures with an average size of $67.7 \mathrm{~nm} \phi$ with a standard deviation of $65.6 \mathrm{~nm}$, as determined by DLS measurements using Avid Nano DLS equipment. The expected average molecular weight for oxLDL was $85013.13 \mathrm{kDa}$, corresponding to a polydispersion \% of 0.94 .

\subsection{Synthesis of the plastic antibody material}

The synthesis of the MAPS material was divided into two parts, using two Au-SPEs where only the gold working areas of the electrodes were modified. All solutions were added after washing out the surface with water or buffer from the previous one. All experiments were conducted at room temperature, except the incubation of oxLDL on $\mathrm{Au}-\mathrm{SPE} / 1$ that was carried out at $4{ }^{\circ} \mathrm{C}$.

$\mathrm{Au}-\mathrm{SPE} / 1$ was modified by drop-coating a plasticized PVC$\mathrm{COOH}$ layer on the gold support. This polymer was then left to dry for 1 day and modified by incubation in NHS for 10 minutes and subsequent reaction with EDAC/NHS solutions for 2 hours. oxLDL solution was added next and left for 4 hours. The surface was then left overnight with the charged monomers. Polymerization was conducted for 5 hours by first adding MAA and EGDMA solutions to the modified support, and then BPO. Finally, the surface was again similarly modified by the same EDAC/NHS reaction, and washed. Au-SPE/ 2 was modified by incubating the $\mathrm{Au}$ area with MPA for 20 hours. This new layer was subsequently incubated in NHS for 10 minutes and made react with EDAC/NHS solutions for 2 hours. EA solution was then added and left for 1 hour.

The surfaces of SPE/ 1 and SPE/ 2 where then aligned and held together under water for $24 \mathrm{~h}$. Au-SPE/2 held the MAPS material that was further treated with proteinase $\mathrm{K}$ for $2 \mathrm{~h}$ and thoroughly washed with water. NIM surfaces were prepared by using a similar protocol, where the addition of oxLDL and charged monomers was replaced by buffer/water.

\subsection{Electrochemical assays}

The MAPSs and NIMs were tested by incubating MAPS or NIM devices in oxLDL standard solutions of $2.5 ; 5.0 ; 7.5 ; 10.0 ; 12.5$; 25.0; and/or $50.0 \mu \mathrm{g} \mathrm{mL}^{-1}$. This incubation period was set to 15 minutes. The oxLDL solutions were prepared in buffer or in FCS solution, using these solutions as the blank of the corresponding standards.

EIS spectra were recorded in $5.0 \mathrm{mmol} \mathrm{L}^{-1}$ iron redox couple solution. A standard potential of $0.12 \mathrm{~V}$ was applied for this purpose, using a sinusoidal potential perturbation of $0.01 \mathrm{~V}$ and 50 frequencies logarithmically distributed over a frequency range of $0.1-100 \mathrm{kHz}$.

The selectivity of the MAPS surface was tested against native LDL, Myo and $\mathrm{Hb}$ solutions, of $50 \mu \mathrm{g} \mathrm{mL} \mathrm{m}^{-1}$ prepared in buffer. The surface was left in contact with these up to a maximum of $1 \mathrm{~h}$.

\section{Results and discussion}

\subsection{Design of the sensory surface}

The synthesis of MAPS required two different Au-SPEs. Au-SPE/ 1 was used to create the SPAM material, but ensuring that the 


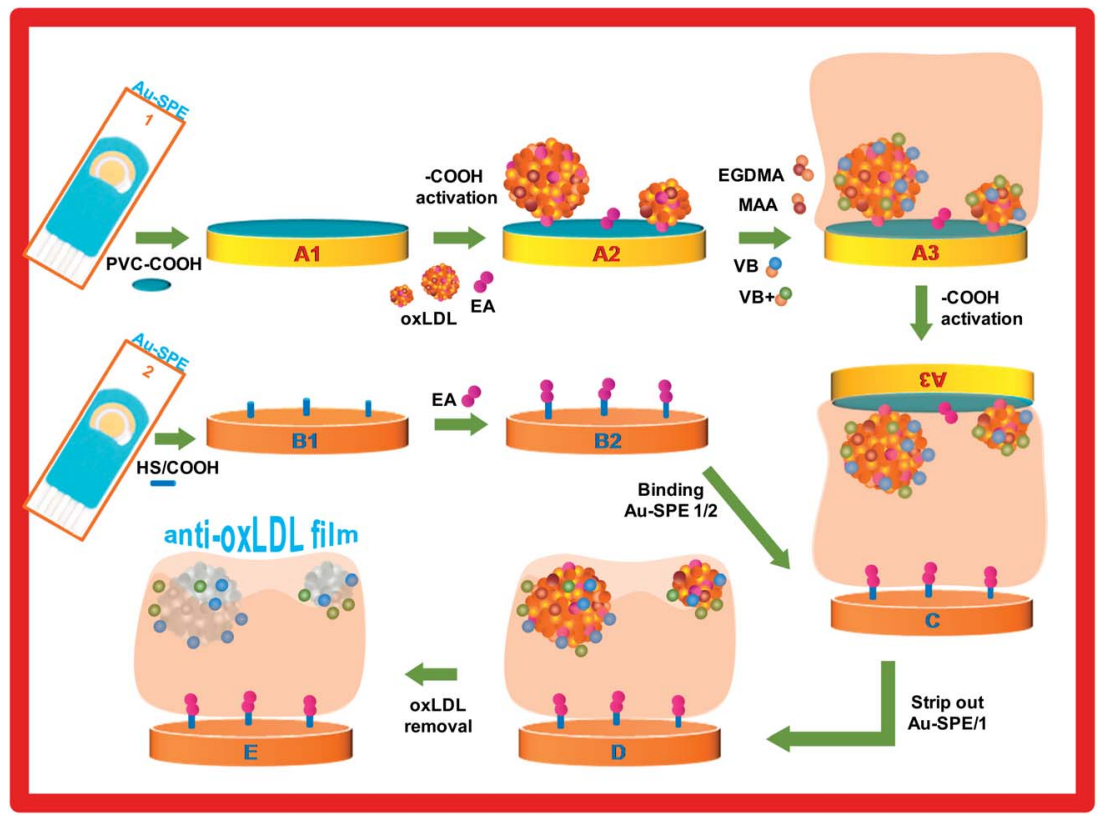

Fig. 1 Assembly of the MAPS material by chemical modification of two separate Au-SPEs.

polymer layer was thick enough to cover the all template compounds present. Au-SPE/2 received this SPAM material in $\mathrm{Au}-\mathrm{SPE} / 1$, exposing in this way the template layer that was linked to the first SPE, which was indeed the MAPS sensory surface (playing an anti-oxLDL role). All chemical modifications made are shown in Fig. 1.

$\mathrm{Au}-\mathrm{SPE} / 1$ was first coated with a polymeric layer (Fig. 1A1). In order to ensure covalent binding of the oxLDL particles, where many $-\mathrm{COOH}$ and $-\mathrm{NH}_{2}$ functions are present, this layer could be composed of amine or carboxylic acid functions. But this layer should also ensure a strong bonding to the Au support on one side and to the oxLDL template on the other side. A thin film of plasticized poly(vinyl chloride) carboxylated (PVC$\mathrm{COOH}$ ) was found suitable for this purpose. This plasticized polymer showed rubber properties, and remained well attached to the $\mathrm{Au}$ working electrode. $\mathrm{PVC}-\mathrm{COOH}$ solution prepared without the plasticizer, o-nitrophenyl octyl ether (oNPOE), was also tested, but the physical bond to the Au layer was not as efficient.

The $-\mathrm{COOH}$ groups on top of this layer were subsequently activated for covalent binding of the template. This was done by the well-known $N$-(3-dimethylaminopropyl)- $N$-ethylcarbodiimide hydrochloride (EDAC)/ $N$-hydroxysuccinimide (NHS) chemistry. ${ }^{30}$ This reaction leads to an ester intermediate that reacts promptly with any available amine group in oxLDL. The corresponding reactions may be followed by analogy in (ref. 31). Thus, once oxLDL was added to the Au-SPE/1 surface, it bound readily to the formerly activated carboxylic groups, thereby forming an amide bond (Fig. 1A2). Ethylenediamine (EA) was added next to deactivate the $-\mathrm{COOH}$ groups that remained active after binding the oxLDL particles (Fig. 1A2).

The imprinting stage started by introducing charge labels around the oxLDL on the Au-SPE/1 (Fig. 1A3). This was achieved by a pre-monomeric arrangement established by means of ionic/electrostatic interactions between the accessible charged sites of the template located on the outer surface and vinyl monomers carrying charged groups. Vinyl benzoate (VB, polar) and VB+ (vinylbenzyl trimethylammonium chloride, positively charged) were used for this purpose. After this, the surface was incubated in methacrylic acid (MAA) and ethylene glycol dimethacrylate (EDGMA), to proceed with the polymerization and formation of a rigid and highly reticulated matrix around the template. This polymerization was initiated by benzoyl peroxide (BPO), a radical species, thus avoiding the introduction of unnecessary ionic charged species inside the polymeric matrix. This polymerization reaction was conducted for a long time, ensuring that oxLDL was completely covered by the newly formed polymer. The functional groups at the outer surface of $\mathrm{Au}-\mathrm{SPE}-1$ were now -COOR (ester) or - $\mathrm{COOH}$. These groups were activated before binding this layer to the other SPEs, by following the same EDAC/NHS chemistry as previously indicated.

$\mathrm{Au}-\mathrm{SPE}-2$ was prepared in parallel, making use of similar chemistry. 3-Mercaptopropionic acid (MPA) was placed first on $\mathrm{Au}$. It comprised a three carbon chain with a carboxylic group $(-\mathrm{COOH})$ on one end and a thiol function $(-\mathrm{SH})$ on the other end. The contact between $\mathrm{Au}$ and $-\mathrm{SH}$ lead to the spontaneous formation of a strong $\mathrm{Au}$-sulphur interaction and the formation of a stable carboxylic layer on the outer surface of the gold support (Fig. 1B1). This surface as further activated by EDAC/ NHS chemistry and added to ethylene diamine, in order to generate an amine layer at the outer surface of the Au-SPE/2 (Fig. 1B2).

Au-SPE-1 and Au-SPE-2 were then joined by facing the sensory materials against each other and clipping the SPE supports (Fig. 1C). This combination was submerged in water, 
in order to ensure an aqueous environment for the reaction to proceed. At this stage, the activated groups in $\mathrm{Au}-\mathrm{SPE} / 1$ were allowed to react with the amine groups in Au-SPE/2, binding the two SPEs together.

Upon separation of the two SPEs, Au-SPE/1 kept the polymeric layer and most probably part of the oxLDL covalently bound to it, while $\mathrm{Au}-\mathrm{SPE} / 2$ exposed a sensing layer where the ox-LDL bound to the polymer film was placed at the same z-level (Fig. 1D). In this separation, it was highly probable that most parts of the template would remain in $\mathrm{Au}-\mathrm{SPE} / 1$, because the polymeric network around it could have prevented the template from coming out connected to the PVC-COOH film. Assuming such possibility, complete template removal was granted by incubating the sensing layer of SPE-2 in proteinase $\mathrm{K}$. Proteinase $\mathrm{K}$ cleaved the peptide bonds of the template under mild conditions and subsequently destroyed the polypeptide structure inside the polymer (Fig. 1E). The template was thus removed without disrupting the existing polymeric matrix. The MAPS sensory surface was obtained after removing the peptide fragments from the imprinted sites by thorough rinsing with buffer and water.

\subsection{Follow-up of the chemical modifications on the Au-SPE}

Since the successive chemical modifications of the area of the working electrode changed their electrical features, the assembly of the anti-oxLDL film was followed-up indirectly by monitoring the electron transfer capability of the Au-SPE for the redox pair $\left[\mathrm{Fe}(\mathrm{CN})_{6}\right]^{4-} /\left[\mathrm{Fe}(\mathrm{CN})_{6}\right]^{3-}$. This was done by electrochemical impedance spectroscopy EIS, using the Randle's circuit for modelling the experimental data. This circuit was selected for being the simplest and the most frequently employed in gold-based immunosensing. ${ }^{32}$ It comprises the uncompensated resistance of the electrolyte $\left(R_{\mathrm{S}}\right)$, in series with the capacitance of the dielectric layer $\left(C_{\mathrm{dl}}\right)$ and the chargetransfer resistance $\left(R_{\mathrm{ct}}\right.$, inversely proportional to the rate of electron transfer), if a redox probe is present in the electrochemical cell. The two latter components are connected in parallel. An additional component, connected in series with $R_{\mathrm{ct}}$, the Warburg impedance $\left(Z_{\mathrm{w}}\right)$, accounts for the diffusion of ions from the bulk electrolyte to the electrode interface.

EIS data were presented in the form of Nyquist plots (Fig. 2). In this, the imaginary impedance component ( $\mathrm{Z}^{\prime \prime}$, out-of-phase) was plotted against the real impedance component $\left(\mathrm{Z}^{\prime}\right.$, inphase) at each frequency. As expected, these plots showed a semicircle region lying on the real axis at a high frequency range, indicating a charge-transfer controlled process in which its diameter $\left(R_{\mathrm{CT}}\right)$ equalled the electron transfer kinetics of the redox-probe at the electrode interface. This region was followed by a linear behaviour in the lower frequency range, implying a mass-transfer limited process. ${ }^{32}$

The bare gold support of $\mathrm{Au}-\mathrm{SPE} / 1$ and $\mathrm{Au}-\mathrm{SPE} / 2$ showed a very small semicircle domain, suggesting a very fast electrontransfer process with a diffusional limiting step (Fig. 2B). The consecutive attachment of the PVC-COOH, oxLDL and polymer gave rise to consecutive increases in the electron transfer resistance, resulting in increases in the semicircular section of

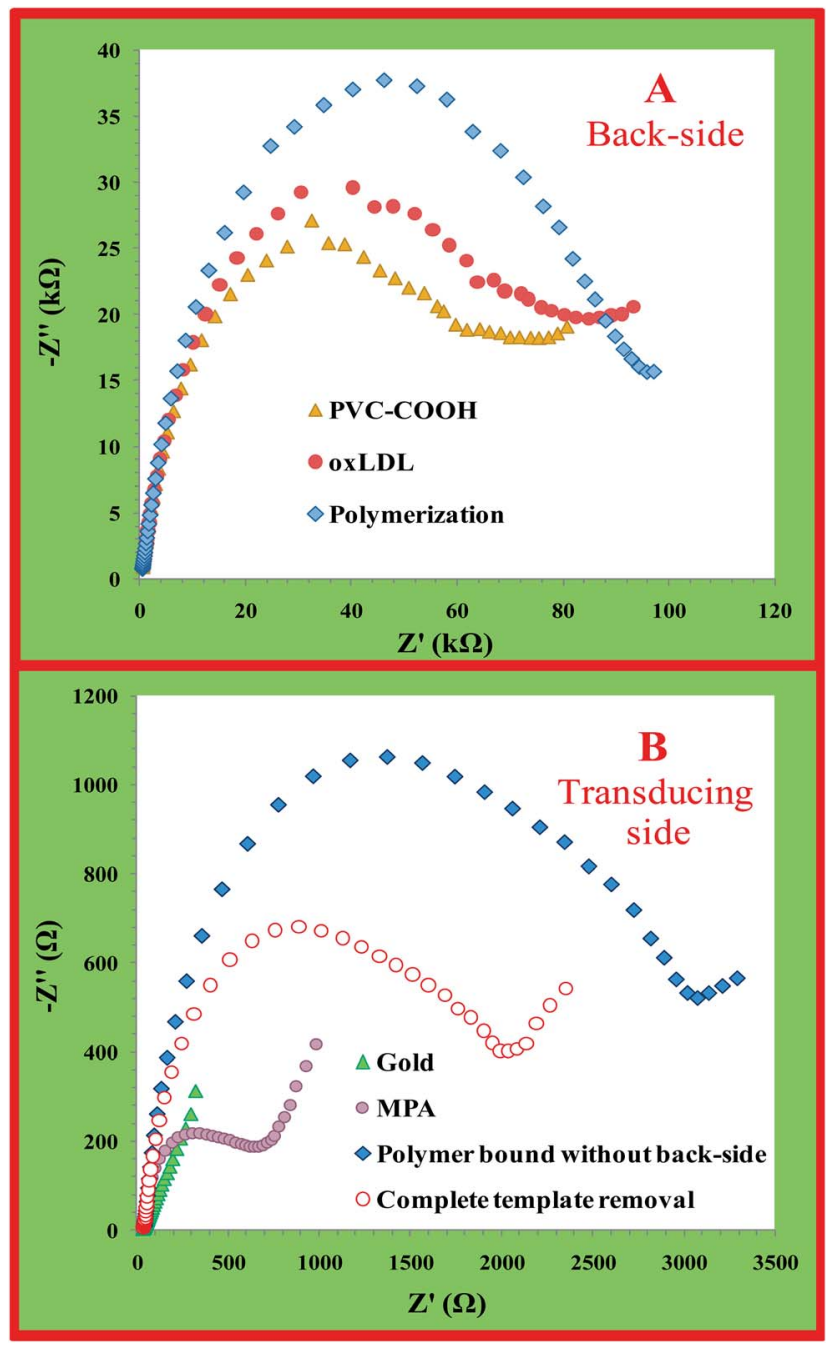

Fig. 2 EIS spectra of the chemical modifications on the supporting film, acting as "backside" of the material (A, Au-SPE/1) and the subsequent assembly of the transducing-side part of the device, including its link to the back-side polymer, back-side removal and complete template exclusion (B, Au-SPE/2).

the Nyquist plot (Fig. 2A). The binding of MPA to the Au in SPE/2 also contributed to a moderate $R_{\mathrm{CT}}$ increase (Fig. 2B), as expected for thiol compounds of small carbon chains bound to gold. Compared to this, the subsequent binding of the polymer layer formed on SPE/1 promoted a huge increase in $R_{\mathrm{CT}}$. This increase was however much smaller than that observed in the original SPE/1, implying that the polymer transfer was not complete. Part of oxLDL was however present within this polymer film in SPE/2, because the subsequent action of protease decreased the $R_{\mathrm{CT}}$ value. The removal of oxLDL reduced the presence of negatively charged species in the polymeric film, which decreased the resistance of a redox probe that was also negatively charged.

The Raman spectra of MAPS and NIM materials were also recorded aiming to find any chemical differences between these. According to the recorded spectra, no differences were observed between the corresponding biosensory surfaces. The obtained spectra are shown in Fig. 3. 


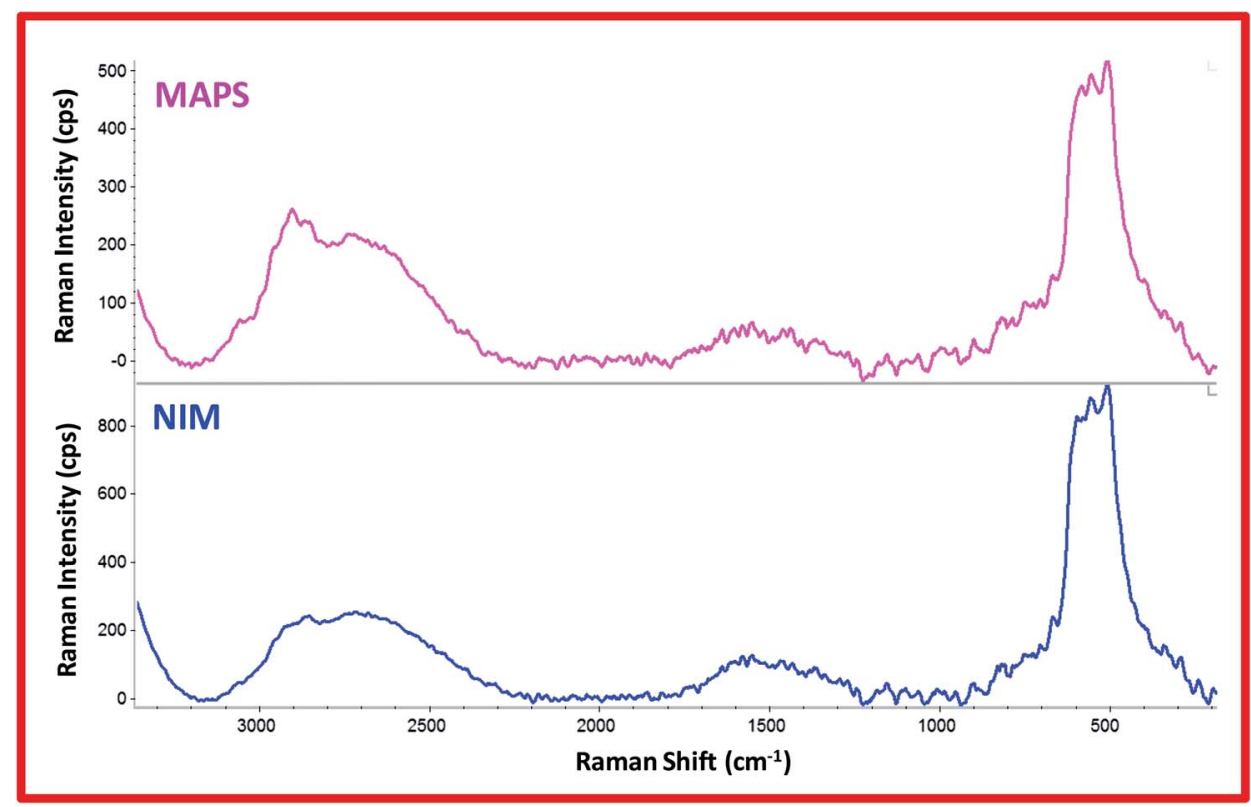

Fig. 3 Raman spectra of the MAPS and NIM material.

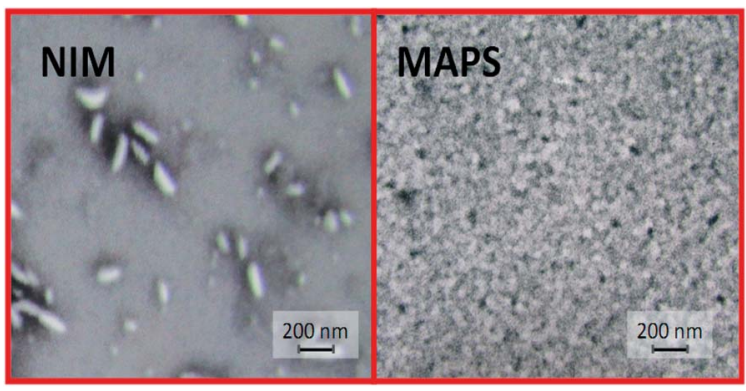

Fig. 4 SEM images of the non-imprinted surface (left, NIM) and imprinted material (right, MAPS).

\subsection{SEM studies}

NIM and MAPS were observed by scanning electron microscopy (SEM) and were shown as completely different materials. The obtained images are displayed in Fig. 4.

The MAPS surface showed a high density of "pores" of different sizes (Fig. 4, right). These pores were the oxLDL binding sites, being correlated with the exit of the oxLDL from the polymeric network. This was supported by changes in the pore size, because it ranged in agreement with the range of sizes of the oxLDL template, as measured by dynamic light scattering (DLS). The average size was $67.7 \mathrm{~nm} \phi$ and the standard deviation was equal to $65.6 \mathrm{~nm}$.

NIM materials showed small agglomerates of the polymer on the surface (Fig. 4, left). This observation was completely unexpected and may correspond to the presence of $\mathrm{PVC}-\mathrm{COOH}$ residues remaining after the separation of SPE/1 and SPE/2.

\subsection{Response of the materials against oxLDL}

The ability of the MPAS surface to interact with the targeted template was also followed by EIS. For this purpose, a solution of $50 \mu \mathrm{g} \mathrm{mL}^{-1}$ of oxLDL was placed in contact with this type of surface for several periods of time, up to 30 minutes. In general, the $R_{\mathrm{CT}}$ value of the blank surface (incubated in PBS) increased with the presence of $50 \mu \mathrm{g} \mathrm{mL} \mathrm{m}^{-1}$. The maximum increase in $R_{\mathrm{CT}}$ was observed after 15 minutes of incubation and the resulting $R_{\mathrm{CT}}$ value remained approximately constant for longer incubation periods. All further studies were conducted for a 15 minute incubation period for oxLDL. The typical EIS spectra for PBS and oxLDL solutions are seen in Fig. 5A.

The effect of the imprinting process upon the electrical response of the material was further tested by comparing the response of the MAPS surface to the NIM one. Unexpectedly, the incubation of the material in PBS or in oxLDL gave rise to the same electrical signal (Fig. 5B). This meant that the NIM surface was unable to establish specific/non-specific interactions with the template. This was mostly surprising because the imprinted template was composed of different species, bearing different sizes. This behaviour indicated the absence of non-specific binding in NIM surfaces and suggested a specific response for the MAPS material.

\subsection{Selectivity study}

The ability of MAPS (plastic anti-oxLDL) to discriminate oxLDL nanostructures from parent or coexisting compounds in serum was checked by incubating the material in native LDL, myoglobin (Myo) and human haemoglobin ( $\mathrm{Hb}$ ). This was done by placing a drop of the corresponding solution on the MAPS surface and incubating it for a suitable period of time. This study was conducted with solutions of $50 \mu \mathrm{g} \mathrm{mL} \mathrm{m}^{-1}$ of interfering species, the same concentration as that of the oxLDL solution, but higher concentrations than those expected in real serum. The time given for an affinity reaction with the sensory material 


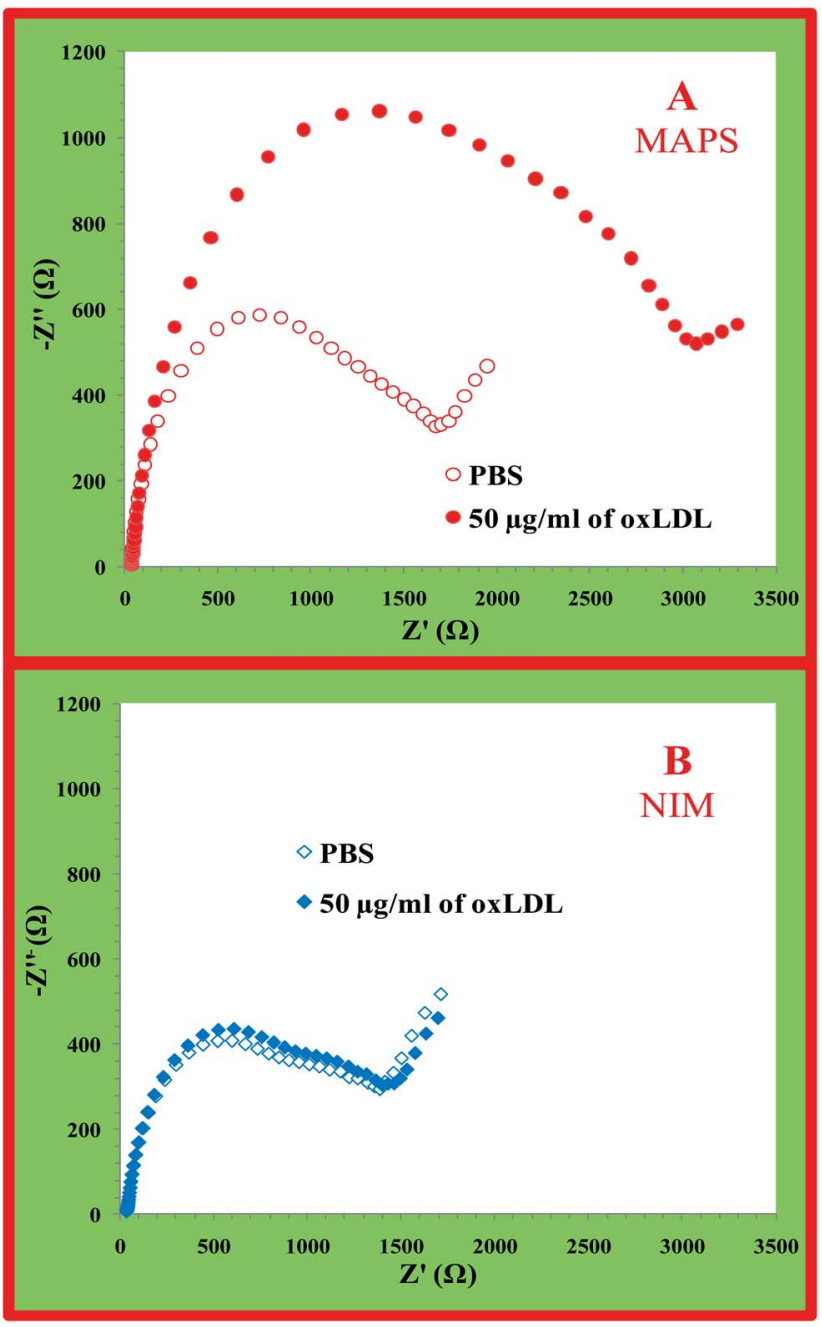

Fig. 5 EIS spectra of the MAPS and NIM with oxLDL solution of high concentration, prepared in buffer.

was set to 1 hour, to strengthen its possible interaction with any interfering species.

As may be seen in Fig. 6, Myo or $\mathrm{Hb}$ was unable to change the profile of the oxLDL EIS spectrum (Fig. 6A and B). This result was extraordinary considering that the imprinted material was highly heterogeneous in size and chemical structure. Furthermore, the MAPS surface was unable to react with side-proteins, not even by means of non-specific interactions.

The presence of native LDL on MAPS gave rise to a little increase in $R_{\mathrm{CT}}$ (Fig. 6C). This little increase could have been correlated with the high structural similarity between native LDL and the corresponding imprinted oxidized fragments. However, there is a great chance that this observation reflects the small fraction of oxidized species existing in circulating LDL.

Overall, the obtained selectivity data pointed out the possibility of using the MAPS material as a recognition surface for oxLDL determination in serum, and therefore in patients with normal or over-concentration of the targeted antigens.

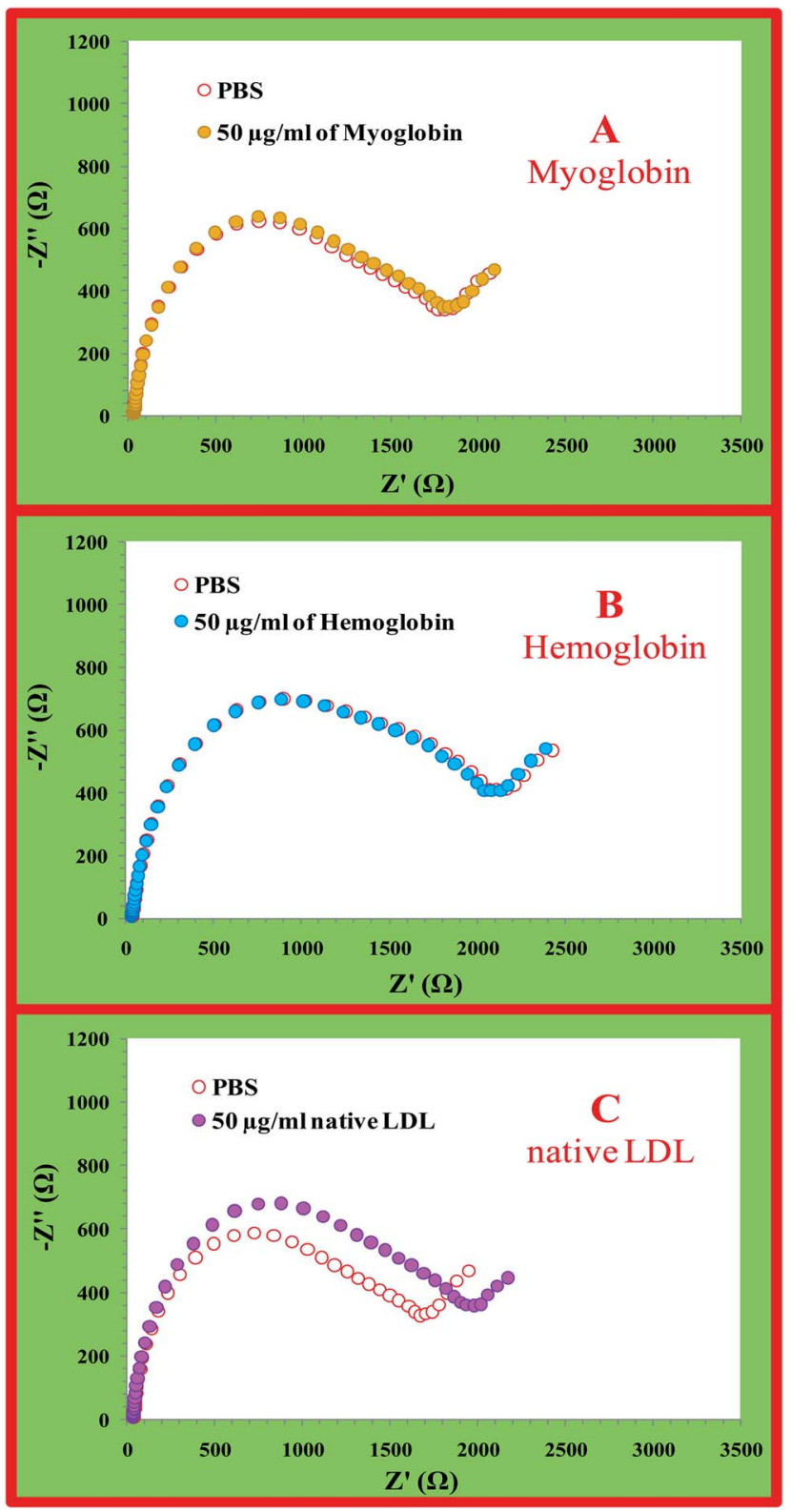

Fig. 6 EIS spectra of the MAPS device in PBS buffer and in different side-biomolecules that may be present in serum.

\subsection{Sensing oxLDL in serum}

Considering that the anti-oxLDL surface should operate well in serum to be useful in clinical context, it is important to check the performance of the MAPS under close-to-real conditions. This was done by replacing the buffer in the standard solutions used to calibrate the EIS calibration of the MPAS-device by nondiluted FCS solutions (equal to the biological composition). FCS was used for this purpose because of its great similarity to human serum. ${ }^{33}$

The EIS spectra of the MAPS surface tested with oxLDL in FCS solution showed clear evidence of the presence of oxLDL, leading to a significant increase in $R_{\mathrm{CT}}$. To ensure that this increase in $R_{\mathrm{CT}}$ did not come from FCS, the individual signal of 


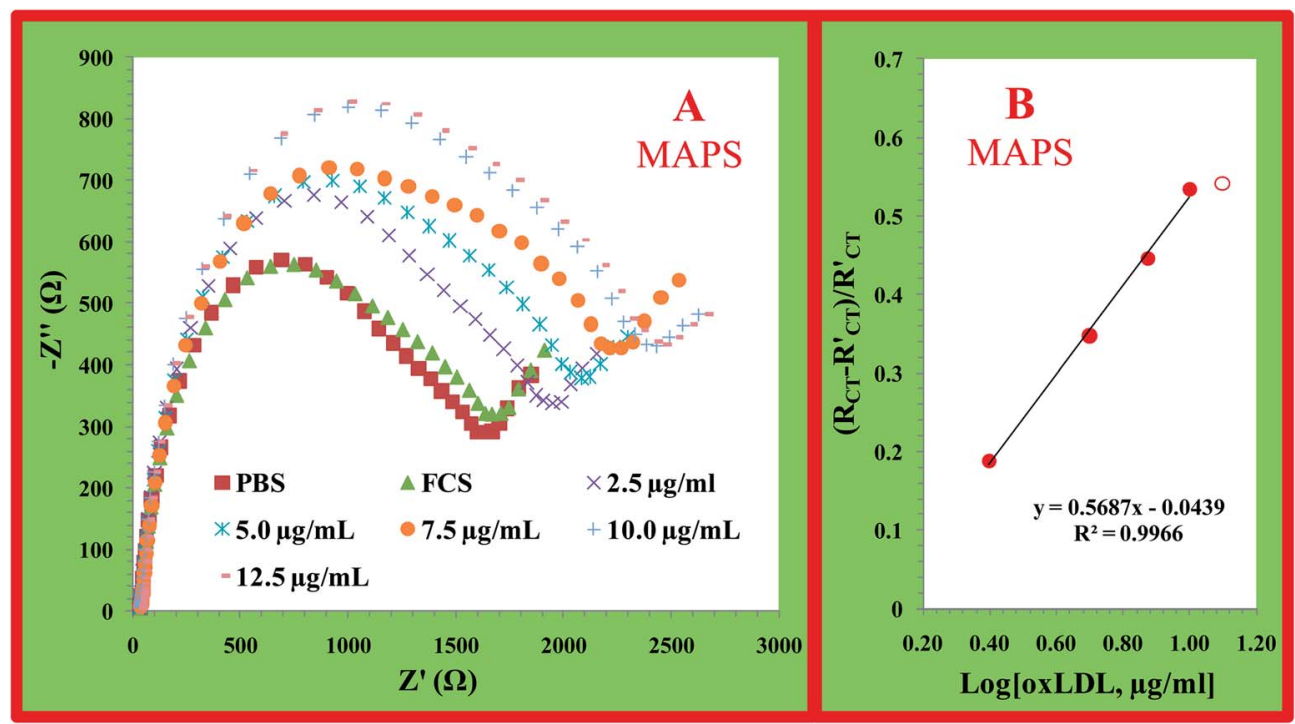

Fig. 7 EIS spectra of the MAPS device tested on an FCS background (A) and the corresponding calibration curve (B), plotting $R_{C T}$ experimental signals corrected against the signal of FCS in blank solutions.

an FCS solution was measured by incubating the MAPS surface in a solution containing FCS and no human oxLDL $\left(0 \mu \mathrm{g} \mathrm{ml} l^{-1}\right)$. As may be seen in Fig. 7A, only negligible differences were observed between this and PBS. This result is also in agreement with the great selectivity of the material reported in the previous point.

The analytical performance of the immunosensor in FCS solutions was checked by calibrating the device with oxLDL standards prepared in FCS. Since all samples would need at least one dilution step prior to analysis, diluted FCS was used for this purpose. The oxLDL concentration range was changed from $0.0 \mu \mathrm{g} \mathrm{mL} \mathrm{m}^{-1}$ (FCS without human oxLDL) up to $50 \mu \mathrm{g}$ $\mathrm{mL}^{-1}$. The typical EIS spectra are seen in Fig. 7B. The values of $R_{\mathrm{CT}}$ plotted against concentration displayed a curved behaviour, very common to real antigen/antibody interaction and similar to Michaelis-Menten kinetics. For commodity reasons, results were linearized by plotting the logarithm concentration against relative $R_{\mathrm{CT}}$. Relative $R_{\mathrm{CT}}$ was used to correct any differences that may be observed in the active surface of different MAPSSPEs. The linear portion of the response was observed up to $10 \mu \mathrm{g} \mathrm{mL} \mathrm{m}^{-1}$, and after that the material seemed saturated (Fig. 7B). The linear response in FCS serum, and thus similar to real conditions, was observed from 2.5 to $10 \mu \mathrm{g} \mathrm{mL}^{-1}$. This region is within the normal range of oxLDL levels, meaning that the presented material offers potential use in human serum having normal and higher levels of oxLDL.

\section{Conclusions}

This novel backside surface imprinting process, where the polymer thickness is no obstacle for the formation of binding sites, was proved successful for targeting a heterogeneous mixture of biomolecules generated by the oxidation of LDL. The material so prepared seemed to offer a specific response for the targeted antigens and a mechanistic response close to biological systems. In general, the chemical functions that were used to assemble the binding sites are different from the ones used to assemble the polymeric network around the template, leading to different electrostatic environments inside and outside the binding position. Inside the binding sites, there are positive charges and polar functions that are expected to be exposed and to interact directly with the template. So, the interaction of oxLDL with the corresponding binding sites is promoted by electrostatic interactions, in a supramolecular arrangement that resembles 'host-guest' electrostatic interactions.

Since the sensory surface is synthetic, it may also be reused to target new concentrations of oxLDL solution, lying in an upper or lower concentration range than the one tested before, provided that the surface is suitably washed.

Overall, this MAPS concept opens a new path to generate plastic antibodies, creating new expectations in the possibility of generating synthetic materials acting close to monoclonal natural antibodies. The remarkable selectivity observed in MAPS may generate further a new line of devices for diagnosis in point-of-care of different biomolecules of clinical relevance. Ultimately, MAPS sensory materials may replace the use of natural antibodies in conventional diagnosis (mostly ELISA) and contribute to save many animals that are today being used/ sacrificed solely for this purpose.

\section{Acknowledgements}

GCM acknowledges CAPES (Coordenação de Aperfeiçoamento de Pessoal de Nível Superior, Brazil) and CNPq (Conselho Nacional de Desenvolvimento Científico e Tecnológico, Brasil, programa Ciência sem Fronteira) for the financial support. ScanSci spectroscopic solutions is acknowledged for use of the Avid Nano equipment for Dynamic Light Scattering 
measurements. WITec $\mathrm{GmbH}$ is acknowledged for accessing the use of SEM equipment from JEOL.

\section{References}

1 M. T. Madigan, J. M. Martinko, D. A. Stahl and D. P. Clark, Immune Mechanisms, in Brock, Biology of Microorganisms, Benjamin Cummings, Pearson Education, 13th Edn, 2012, ch. 30 , p. 850 .

2 N. S. Lipman, L. R. Jackson, L. J. Trudel and F. Weis-Garcia, ILAR J., 2005, 46, 258.

3 G. Köhler and C. Milstein, Nature, 1975, 256, 495-497.

4 A. Bossi, F. Bonini, A. P. F. Turner and S. A. Piletsky, Biosens. Bioelectron., 2007, 22, 1131-1137.

5 N. W. Turner, C. W. Jeans, K. R. Brain, C. J. Allender, V. Hlady and D. W. Britt, Biotechnol. Prog., 2006, 22, 1474.

6 M. V. Polyakov, Zh. Fiz. Khim., 1931, 2, S799-S804.

7 T. Zhu, D. Xu, Y. Wu, J. Li, M. Zhou, T. Tian, Y. Jiang, F. Li and G. Li, J. Mater. Chem. B, 2013, 1, 6449-6458.

8 S. Xu, H. Lu, X. Zhenga and L. Chen, J. Mater. Chem. C, 2013, 1, 4406-4422.

9 S. Piletsky and A. Turner, in Molecular Imprinting of Polymers, Biotechnology Intelligence Unit, Landes Bioscience, 2006.

10 N. W. Turner, C. W. Jeans, K. R. Brain, C. J. Allender, V. Hlady and D. W. Britt, Biotechnol. Prog., 2006, 22, 474-489.

11 T. Takeuchi and T. Hishiya, Org. Biomol. Chem., 2008, 6, 2459-2467.

12 M. J. Whitcombe, I. Chianella, L. Larcombe, S. A. Piletsky, J. Noble, R. Porter and A. Horgan, Chem. Soc. Rev., 2011, 40, 1547-1571.

13 S. M. Reddy, G. Sette and Q. Phan, Electrochim. Acta, 2011, 56, 9203-9208.

14 G. Guan, B. Liu, Z. Wang and Z. Zhang, Sensors, 2008, 8, 8291-8320.

15 M. Komiyama, T. Takeuchi, T. Mukawa and H. Asanuma, in Molecular Imprinting, from Fundamentals to Applications, Wiley-VCH Verlag GmbH \& Co. KGaA, 2003.
16 S. Koutsopoulos, Adv. Drug Deliver. Rev., 2012, 64, 1459-1476. 17 L. Chen, S. Xu and J. Li, Chem. Soc. Rev., 2011, 40, 2922-2942. 18 N. M. Bergmann and N. A. Peppas, Prog. Polym. Sci., 2008, 33, 271-288.

19 D. S. Janiak and P. Kofinas, Anal. Bioanal. Chem., 2007, 389, 399-404.

20 E. Verheyen, J. P. Schillemans, M. van Wijk, M. A. Demeniex, W. E. Hennink and C. F. van Nostrum, Biomaterials, 2011, 32, 3008-3020.

21 A. L. Hillberg and M. Tabrizian, IRBM, 2008, 29, 89-104.

22 A. M. Bossi, P. S. Sharma, L. Montana, G. Zoccatelli, O. Laub and R. Levi, Anal. Chem., 2012, 84, 4036-4041.

23 Z. Lin, Z. Xia, J. Zheng, D. Zheng, L. Zhang, H. Yang and G. Chen, J. Mater. Chem., 2012, 22, 17914-17922.

24 F. T. C. Moreira, S. Sharma, R. A. F. Dutra, J. P. C. Noronha, A. E. G. Cass and M. G. F. Sales, Biosens. Bioelectron., 2013, 15, 237-244.

25 H. Puhl, G. Waeg and H. Esterbauer, Methods Enzymol., 1994, 233, 425-441.

26 A. Zaratin, M. Gidlund, P. Boschcov, L. Castilho and E. C. Faria, Am. J. Cardiol., 2002, 90, 651-653.

27 R. J. Havel, H. A. Eeder and J. H. Gragdon, J. Clin. Invest., $1955,34,345$.

28 O. H. Lowry, N. J. Rosebrough, A. L. Farr and R. J. Randall, J. Biol. Chem., 1951, 193, 265-275.

29 E. C. Fernvik, D. F. Ketelhuth, M. Russo and M. Gidlund, J. Clin. Immunol., 2004, 24, 170-176.

30 K. Y. Jiang, L. S. Schadler, R. W. Siegel, X. J. Zhang, H. F. Zhang and M. Terrones, J. Mater. Chem., 2004, 14, 37-39.

31 F. T. C. Moreira, R. A. F. Dutra, J. P. C. Noronha, A. L. Cunha and M. G. F. Sales, Biosens. Bioelectron., 2011, 28, 243-250.

32 M. I. Prodromidis, Electrochim. Acta, 2010, 55, 4227-4233.

33 T. Lindl, Zell-und Gewebekultur, Spektrum akademischer Verlag, Heidelberg, 5th edn, 2002. 